\title{
Hybridization of Four Species of Sunfishes (Centrarchidae)
}

\section{WILLIAM F. CHILDERS}

HATURAL HISTORA SW.VEY

DEC 131967

แม⿱中⿰㇀丶㇀
THE LIBRARY OF THE

NaV 301967

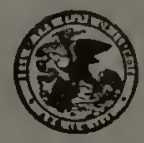





\section{ILLINOIS NATURAL HISTORY SURVEY}

\section{Bulletin}

Volume 29, Article 3

September, 1967

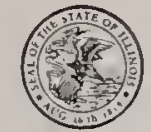

Printed by Authority of the State of Illinois

\section{Hybridization of Four Species of Sunfishes (Centrarchidae)}

WILLIAM F. CHILDERS

SIATE OF ILLINOIS

DEPARTMENT OF REGISTRATION AND EDUCATION

NATURAL HISTORY SURVEY DIVISION Urbana, Illinois 
BOARD OF NATLRAL RESOLRCES AND CONSERIATION

Johx C. Wazson, Chairman; Thomas Park, Ph.D., Biology; L. L. Sloss, l'h.D., Geology; Roger Adams, Ph.D. D.Sc, Chemistry; Rodert IL, ANoersos, B.S.C.E., Engineering; Charles E. Olasted, Jh.D., Forestry; ll, L. Everite, E.E. Hh.D., Representing the Presidem of the L"nitersily of llinois; Rocer E. Berier, Ph.D., Repre senting the President of Southern lllinois I'niversity.

\title{
NATURAL HISTORY SURVEY DIVISION, Urbano, Illinois
}

\section{SCIENTIFIC AND TECHNICAL STANF}

\author{
George SPrugel, JR., Ph.D., Chicf \\ HereERT H. Russ. Ph. D. Issistant Chiet \\ ROBERT O. Warsox, B.S., Issistane to the Chicf \\ Alice P. Campelil, B.A., Secretary to the Chicl
}

\section{Section of Economic Entomolagy}

Willam II. Luchmann, PH.D.. Entomulogist and Head

Willis N. Brucl, Ph.D., Entomologist

WAYNE L. Howe, Ph.D.: Entomologist

Rosalo HI. MEver, Ph.D. . Associate Entomologist

James E. ApPleby, Ph.D., Associale Entomologist

RoBert D. Pausch, Ph.D. tssistant Entomologis

Ralph F. Sichkiest, Ph,D.. Assistant Entomologist

DELPH B. Broerssis Ph. D. Assistant Entomologist

JuSEPH I: MADDox, Ph.D.. Assistant Entomologist

EDWard J. Armbrust, Ph.D.. Assistant Entamologist

Clarenci E. White, B.S., Research Assistant

Ranu BanerJee, B.A. Technical fssistant

Douglas K. Selz, B.S., Technical fssistant

SUE F. WATkiNs, Junior Scientific issistane

lloward B. PetTy, Ph.D.. Entomologist, Extension

Stevenson Moore, III. Ph.D.. Entomologist. Extension

Roscere Ravnfit., MIS., Technical Assistant, Eatensien

STAXi.EY RACHEahy, Mi.S.. Technical 1ssistant, Extension

Dovald E. Kuthuman, M.S., Technical fssistent.

Extension

Aial C. Banerjee, Ph.D., Resiarch Associate

lfay G. Wulson, B.A., Research Assaciate

Miargaret J. Jensey, M.S., Rescarch Assistant

KEUN S. PARK. M.S.. Rescarch ftsistant

KETIRAH RLINBOLD, MI.S., Research Assistant

\section{Section of Founistic Surveys and Insect Identification}

HERnERT 11. Ross, Ph.D., Assistant Chict and Head

Miluton II. Sanderson, Ph.D., Taronomise

Lewis J Stavvaro, IR., Ph.D. Taxonomist

Phulla IV Smitit, Ph.D., Taxonomist

Wallace E. LABerge. Ph.D.. Issociate Taxonomist

DoNALD IV. WLuE, M.S., Issistant Taxonomist

Johy D. UNzICKER, Ph.D., Issistant Taronomist

BerNice P. Suenner, Technical Assistant

BEss C. Wurte, A. B., Technical Assistant

\section{Section of Aquatic Biology}

George W. Bennett, Ph.D., Aquatic Biologist and Head

Wuluas C. Starkett, Ph.D. Aquatic Riologist

R. Weldon Lakimore, Ph.D., Inuatic Riolagist

D llonfr Beck, Ph.D., Associate Aquatic Biologist

Rogrkt C. Ilntibran, Ph.D., Issoriate Biochomist

Donald F. Haxsen, Ph.D., Associate tquatic Riologist

Whllam F. Cutlders, Ph.D., Associate Iquatic Biologist

Deyels I Duolfy, Technical Asristant

Mari liraxces Martin, Technical fssistant

(: Russtu. Rose, Field Assistant

Charles F. Turots, 111. B.A. Rescarch fssocial

Sithyen O. i.nunsberri, Project Assistan?

JoN Stelter, Project Issistant

\section{Section of Applied Botany and Plant Pathology}

1. Ceoric Carien, Ph.D., Plant Pathologist and Head

It:Nios L. Forsererg. Ph.D. Plant Palhologist

Rumert A. Finers, Ph.D. Bolanist

R. DAN NeELY, Ph.D. Plant Pathologist

Eugexe B. Htaterck. Ph.D., Plant Puthologist

Donald F. Schoesifwerss, Ph.D., Issaciate Plan!

Pathologist

Walter IIAktstira, Ph.D., Assistant Plant Palhologist

Ge>E E. RejD, Technical fusistant

Betry S. Sistosos, Technical Assistant

\section{Section of Wildlife Research}

Gren C. Sanderson, Ph.D., Wildile Specialist and He'ud Frank C. Bellrose, B.S., I'ildlife Specialist

Ilarold C. Ilanson, Ph.D... I'illlive Specialist

Ricuaro $\dot{R}$ Graber, Ph.D., Wildlife Specialist

Ronald F. Labisky, M.... tssaciate IVildlife Specialist

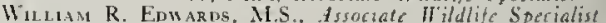

WiLliam IV. CochRax, JR, B.S. Assistant il ildlite Specialist

Robert E. Greenterg, M.S., Reseatch Issuciale

lletex C. Schultz, M.A. Technteal fssistant

Cakolian S. Evros, B.A. Technical dssistant

Robert D. Crompton, Field issistant

Mlaky Ayn Johnson, Tichnical Issistant

Rosald E. Duzas, Technical Assistont

William L. Anloersur, MA. Research Assaciale

Tames A. Balley. Ih.D., Rescarch dysociate

lACK A. Ellits, Mis.. Research Associate

Stancey L. ETter, M.S., Rescarch dssociale

Willaam J. Fraxcis, Pl,D, Rescarch Assoriat

G. Blatr Joselyn, M.S., Research . Issaciate

Ronaln L. WestemeIfr, B.S., Resiarch Issoriate

Groard L STORM, MS Fieid Ecologist

GERAED L. STORM, M.S.. Field Erolngist

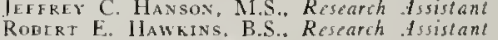

KeIth P. Thomas, M.S., Research issistant

Eleavore Wilsos, Projet Assistant

\section{Section of Publicotions and Public Relations}

OweN F. Gesssendorf, M.S., Technical Editor and Head RoBle T M. ZeWADski, MIS. Associate Techuical Editor PHyils K. Bovfrel.D, B.J.. Assistant Terhnical Editor Wituser D. ZFir, Tichnical Pholographer

Ricuard M. Sizets, Technical lllustrator

\section{Technical Library}

Doris F. Donos, B.A., M.S.L.S., Yechnical Librarian

\section{Administration and Service}

Robert O. Warsox, B.S., Assustant to the Chit'

Grace C. Fixgle, B.S.. Financial Records

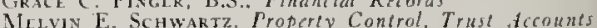
J. Willaw Lusk, Wailing and Distribulion Servies

Tames B. CurTis. Greenhowse Superintendent

Robert $O$. Fleis, Garage Superintendent

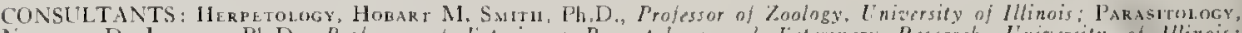
Vor

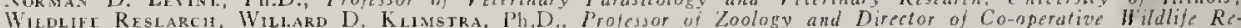
scarch. Southern llinois lniacrsity; Statistics, Horace W. Noktos. Ph.D., Professor nf Siatistical Design and Analysis, liniversuly of lllinois. 


\section{CONTENTS}

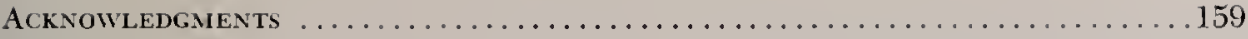

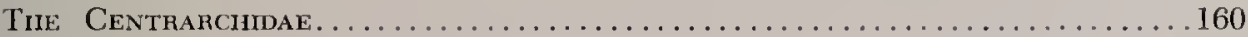

Lepomini Evolution......................................... 161

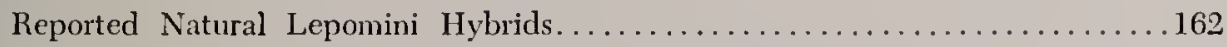

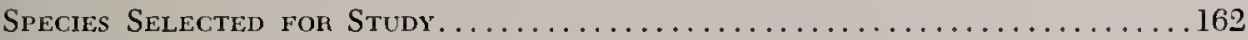

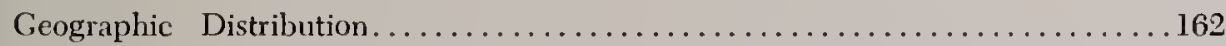

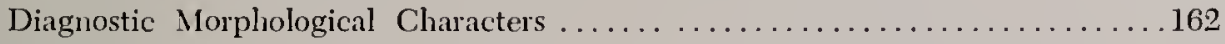

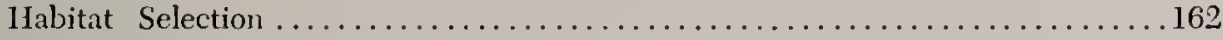

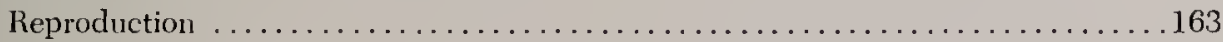

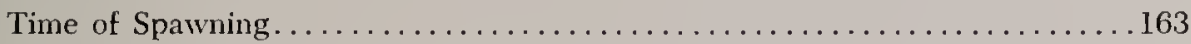

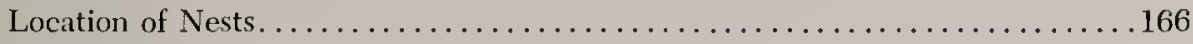

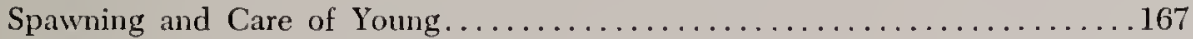

Duration of Fertility of Gametes............................ 167

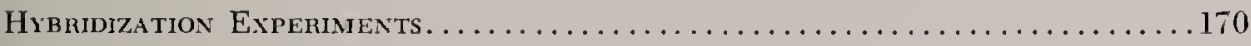

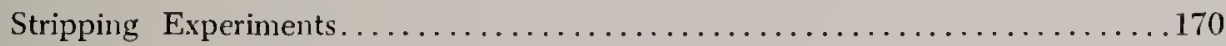

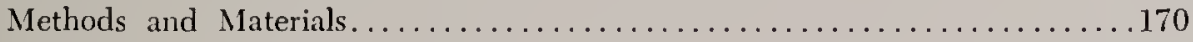

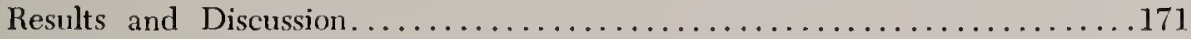

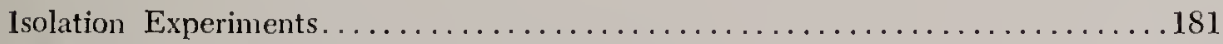

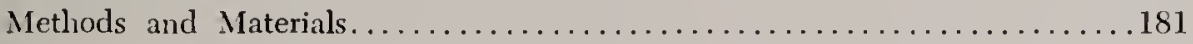

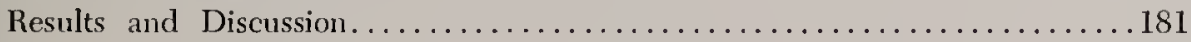

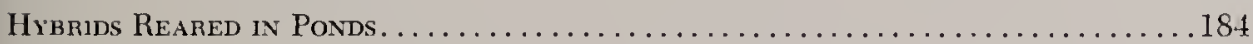

Sex Ratios......................................... 184

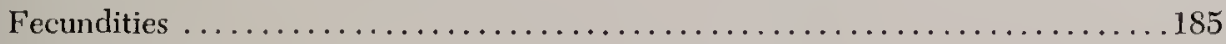

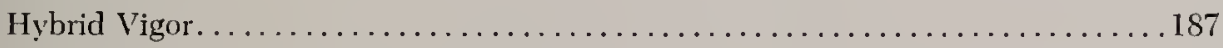

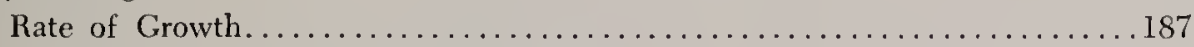

Electrophoretic Patterns of Hemoglobins.......................... 189

Vulnerability to Hook-and-Line Capture ........................ 189

Hrbrid Sunfishes fon Sport Fishinc.............................. 189

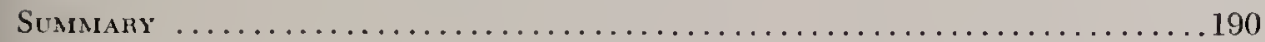

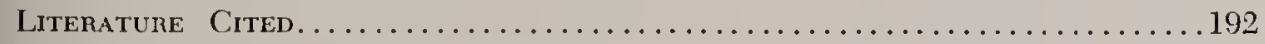

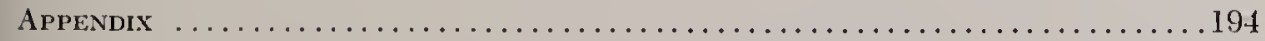

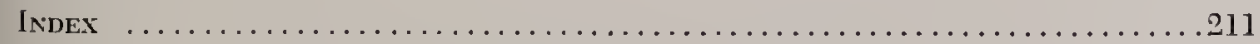

Colon Plate, parent and hybrid sunfishes............... following page 1S4

This report is printed by authority of the State of Illinois, IRS Ch. 127, Par. 58.12. It is a contribution from the Section of Aquatic Biology of the Illinois Natural IIistory Survey.

$$
\text { (39846-5000-9.67) }
$$




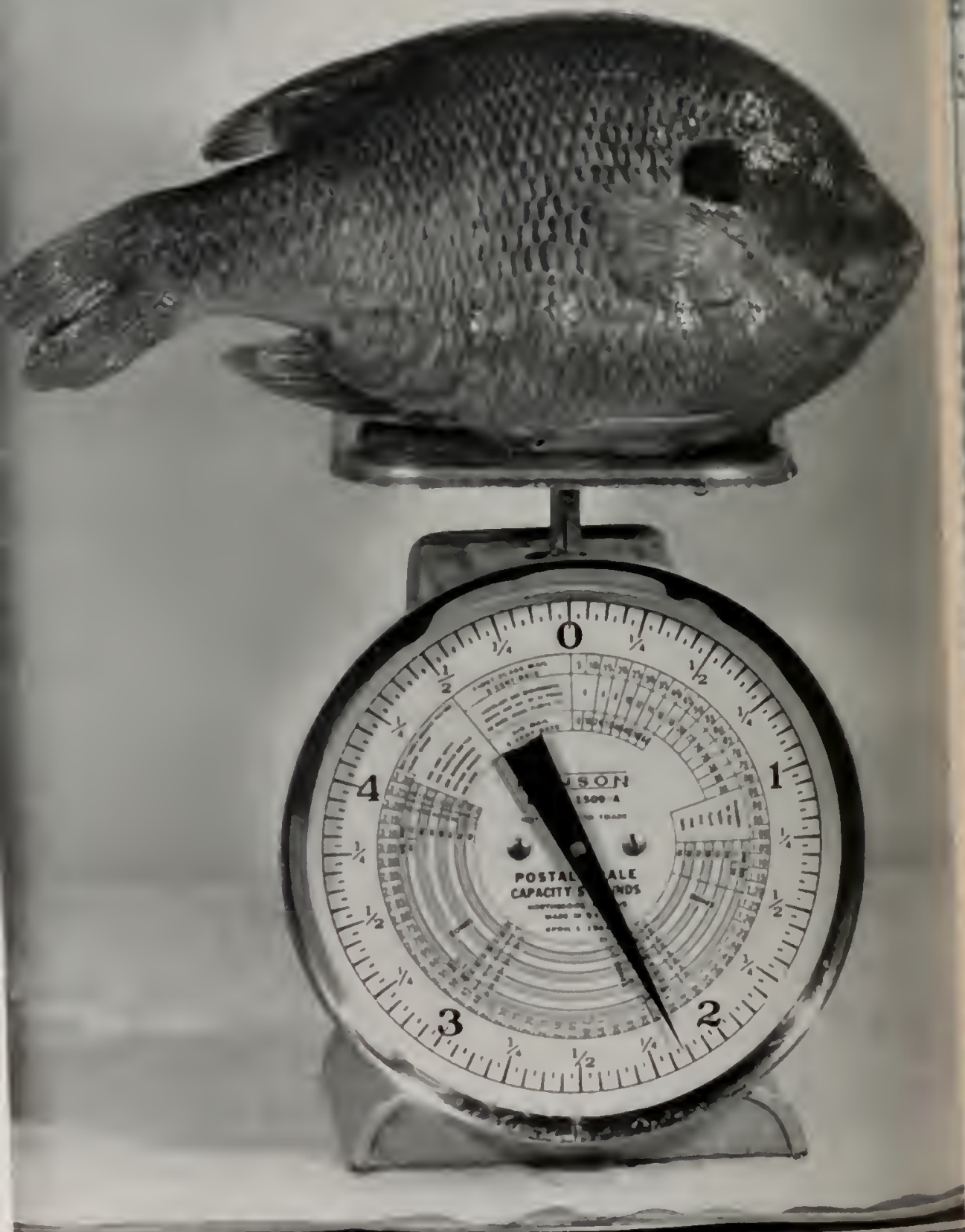

ton 


\section{Hybrdization of Four Species of Sunfishes (Centrarchidae)}

WILLIAM F. CHILDERS

II) RBRHLLATION is very commum "whm nu generol of plonts and has

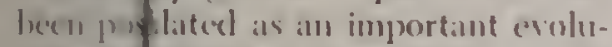
tomary rehanism of speciation in the plant hefelom (Anderson 1953:25:24.3. Ilofer 19.49:6.51, Stehbus 19.59. 245) In we .mimat hingetem, the evohttiman hustance of heprielization is lene elea Ilyburids have Ixeen reported for mesenci.tzom gromps although in onle a f: cases are they hoow to be sell-pe rftuating (Ross 1955:337).

In fis s the incidence of natural hyloriela ion appears to be low: Batiley (1)fithe:3) e'stimates that there are betwere 15,000 and 17,(00) Recent fish speecer, nd Slastenenker (1957:76-91) lists on 167 known natural interspecific lash tivbrids of the wordd. Crossman \& Buw 1965:1261) suggest the possibilits ff three additional hybrids in the I'oddace. Approsimately 90 pereent of thes 170 hybrids were found in freshes rs: the rest occurred in marine or hradsh water environments. About twe-thes of the freshwater hibrids were fol in Nortl America. Ílubbs (195.5: (1S-19) pointed out that hybridizan in has probably been most frecpues in North American freshwaters where fe cisting fish fama became estahlised only as recently as the Miocene. Locene, and Pleistocene epochs. Hublus Iso remarked that a considerable bly of circumstantial evidence indicall that introgressive hybridization h been a significant factor in specialm in the tribe Lepomini of the Centro hidae.

Thederm hybrid has been variously: definel (Darwin 1S97:1-2; Darlington 195S: Stebbins 1959:231). Unless othervie specified. hybrid, as used here, refers to the olfspring of interspecific matings.

\section{ACKNOWLEDGMENTS}

This polper is batsed upon research conducted at the Illinois . Noltural Ilistury Survey: Dr. Ceorge W. Bemett, Heatel of the Atynatio Bielogy Section, supersised this propect and alded in all stage's of the stmd. I lis advice. help. and encouragement were invalualsk.

Most of the restults presented in this paper were included in a thesis submitted to the Unisersity of Illinois in partial fulfillment of the requirements for the degree of Dectere of Plitosophe. Professor Charless. Kendeigh directed III graduate studies, served as chairmant of my dectural committere and ansisted in the revision of my thesis manuscript.

Drs. Wielelon R. Larimore and Donald F. Hansen of the Apruatic Biology Section of the Llthois Natura] History Survey aided in part of the feld work. criticized the manuscript, and made many valuable suggestions churing all stiges of this study: Mr. Rolnert M. Zewadski. Associate Technical Editor of the Surver, edited this paper, and his patience and skill are greatly appreciated. Professor Horace W. Norton of the Cuiversity of Illinois advised and assisted in the statistical analysis of the datis.

I also express my appreciation to my wife, Norma H. Childers, who assisted with laboratory experiments, and to staff members, too numerous to mention individually: of the lllinois Natural Histon Survey and the University of Illinois who contributed to this study:

Mr. William Utterback of Gibson 
City, Mr. and Mrs. G. Maxfield of Fairmount, and Professor Fay H. Root, Assistant Director of Rolsert Allerton Park, donated the use of numerous ponds. The willing eooperation of these people is greatly appreciated.

\section{THE CENTRARCHIDAE}

The Centrarchidae (sunfishes) are a group of freshwater fishes of temperate
North America whose present eenter of distribution is the Mississippi River basin. A complete classification of the extant Centrarchidae is given in the accompanying list. With one exception all 27 speeies were originally limited to freshwaters east of the Rocky Mountains. This exception, the Sacramento perch, Archoplites interruptus (Girard), is a relict form native to Califor-

Classifieation of the Centrarchiclae. The scientific and common names are those suggested by Bailey (1960b: 27) and the subfamily and tribal classification follows that of Branson \& Moore (1962).

Subfamily Centrarchinae

Tribe Ambloplitini

Archoplites intermptus (Girard)

Ambloplites cavifrons Cope

Ambloplites rupest ris (Rafinesque)

Acantharchus pomotis (Baird)

Tribe Centrarchini

Pomoxis nigromaculatus (Lesueur)

Pomoxis annularis Rafinesque

Centrarchus macropterus (Lacépède)

Sacramento pereh

Roanoke bass

Rock bass

Mud sunfish

Black crappie

White crappie

Flier

Subfamily Lepominae

Tribe Enneacantlini

Enneacanthus obesus (Girard)

Enncacanthus gloriosus (Holbrook)

Enneacanthus chactodon (Baird)

Tribe Lepomini

Chacnobryttus gulosus (Cuvier) ${ }^{1}$

Lepomis symmetricus Forbes

Lepomis cyancllus Rafinesque ${ }^{1}$

Lepomis macrochirus Rafinesque ${ }^{1}$

Leponis humilis (Girard)

Lcpomis gibbosus (Linnaeus)

Lepomis microloplus (Günther) ${ }^{1}$

Lepomis punctatus (Valenciennes)

Lepomis marginatus (Holbrook)

Lepomis auritus (Linnaeus)

Lepomis megalotis (Rafinesque)

Tribe Micropterini

Micropterus salmoides (Laeépède)

Micropterus dolomieui Lacépède

Micropterus coosae Hubbs \& Bailey

Micropterus notius Bailey \& Hubbs

Micropterus punctulatus (Rafinesque)

Micropterus treculi (Vaillant \& Bocourt)
Banded sunfish

Bluespotted sunfish

Blackbanded sunfish

Warmouth

Bantam sunfish

Green sunfish

Bluegill

Orangespotted sunfish

Pumpkinseed

Redear sunfish

Spotted sunfish

Dollar sunfish

Redbreast sunfish

Longear sunfish

Largemouth bass

Smallmouth bass

Redeye bass

Suwannee bass

Spotted bass

Guadalupe bass 
nia. In the last 100 years many species have been widely introduced into freshwaters throughout North America and in other parts of the world.

\section{Lepomini Evolution}

On the basis of the fossil record, current natural geographic distribution, and comparative morphology, the evolution of the Lepomini can be hypothesized as follows:

1) The Centrarchidae date from the early Cenozoic and are closely related to the sea basses (Serranidae) (Miller 1958:199).

2) The Mississippi River basin was probably their center of origin (Branson \& Moore 1962:88).

3) A relative abundance of extinct centrarchids in Miocene and Pliocene rocks of Oregon, Nevada, and Utah indicates that the Cen- trarchids' range was much larger then than it is now (Miller 1958: 193, 199).

4) The Rocky Mountain uplift, beginning in the Miocene or early Pliocene and increasing to the end of the era (Schuchert \& Dunbar 1941:386) isolated west coast Centrarchids from those east of the Rocky Mountains.

5) Fossils of the extant species warmouth and black crappie have been found in middle Pliocene deposits in Logan County, Kan. (Branson \& Moore 1962:96).

6) Late Pliocene to early Pleistocene deposits in southern Idaho and eastern Oregon contain a fossilized sunfish which is probably of the genus Lepomis (Miller 1958: 194).

7) During the Pleistocene the west

Lepomini hybrids known to occur in nature.

Kind of Hybrid

Warmouth $\times$ Pumpkinseed

Warmouth $x$ Redbreast sunfish

Warmouth $x$ Green sunfish

Warmouth $x$ Bluegill

Green sunfish $x$ Bluegill

Green sunfish $x$ Pumpkinseed

Green sunfish $x$ Longear sunfish

Green sunfish $\mathrm{x}$ Redbreast sunfish

Green sunfish $x$ Red-ear sunfish

Green sunfish $\mathrm{x}$ Orangespotted sunfish

Bluegill $x$ Red-ear sunfish

Bluegill $x$ Pumpkinseed

Bluegill $x$ Orangespotted sunfish

Bluegill $x$ Longear sunfish

Bluegill $x$ Redbreast sunfish

Pumpkinseed $x$ Orangespotted sunfish

Pumpkinseed $\times$ Redbreast sunfish

Pumpkinsced $x$ Longear sunfish

Longear sunfish $x$ Orangespotted sunfish

Warmouth $x$ Red-ear sunfish

Bluegill $x$ Spotted sunfish
Reference

Radcliffe $(1914: 27)^{2}$

McAtee \& Weed (1915:13) ${ }^{1}$

McAtee \& Weed (1915:13) ${ }^{1}$

Hubbs (1920:102)²

Bailey \& Lagler (1938:58s-60.4)²

Bailey \& Lagler (1938:588-604) ${ }^{2}$

Cross \& Moore (1952:410-411)2

Raney $(1940: 364)^{1}$

Trautman $(1957: 501)^{1}$

Hubbs \& Ortenburger (1929:42) ${ }^{1}$

Cross \& Moore (1952:411)2

Bailey \& Lagler (1938:588-604) 2

Cross \& Moore (1952:411)²

Cross \& Moore (1952:411) ${ }^{2}$

Bailey \& Lagler $(1935: 577)^{1}$

O'Donnell (1953:457) ${ }^{1}$

Greeley \& Bishop (1933:101 $)^{1}$

Hubbs (1926:72)1

O'Donnell (1935:487) ${ }^{1}$

Childers (unpublished)

Stinauer \& Childers (unpublished)

'Contains no description.

'Contains description. 
coast species were probahly restricted to a southern coastal distribution and are represented today by one relic species, the Sacramento perch.

8) During the Pleistocene northern species east of the Rocky Mountains withdrew in a southcasterly direction or became extinet.

9) Speciation in the genus Lepomis probably has proceeded at a rapid rate during the Recent epoch.

\section{Reported Natural Lepomini Hybrids}

It is theoretically possible for the 11 species of Lepomini to hybridize in 110 different $F_{1}$ combinations; however, since it appears impossible morphologically to differentiate between hybrids of reciprocal crosses (Hublos \& Hubbs 1932:433), only 55 morphologically different Lepomini $F_{1}$ hybrids conld be identified. Of this number at least 21 have been found in mature. In the list of naturally occurring Lepomini hybrids (page 161), an attempt has been made to give credit to the author of the first published description of each kind.

\section{SPECIES SELECTED FOR STUDY}

Four species of sunfishes in the tribe Lepomini (red-ear sunfish, bluegill, green sunfish, and warmouth) were selected as experimental species because of local availability; importance to sport fisluing; taxonomic relationships; and similarities and differences in their morphology, habitat selection, and reproductive behavior.

\section{Geographic Distribution}

The natural geographic ranges of the four species greatly overlap one another (Tautman 1957: 497, 500, 504, 517). All four species are sympatric in east-central Illinois, and they are quite abundant in a number of lakes and ponds in this area. Bluegills, green sunfish, and warmouths are indigenous to east-central lllinois, and the red-ear sunfish, a more southem species, was successfully introduced into this area in 1946 (Bennett 1958: 177).

\section{Diagnostic Morphological Characters}

Forbes \& Richardson (19:0:245-251, 257-259) and Trautman (1957:496504, 516-51S) give good morphological descriptions of the four experimental species. Certain key morphological characteristics of the four species are presented in Table I.

\section{Habitat Selection}

Larimore (1957:2), in discussing the distribution of the warmoutl in Illinois, stated that although the warmouth is principally a pond and lake fish, it occurs in the Rock, Mississippi, and Illinois rivers and is reported as common in small, sluggish streams in the southern part of the state. In eastcentral lllinois warmouth are only occasionally found in streams. Many of the creeks and some larger streams in this area have been dredged and are unsuitable for most species of fishes. The undredged portions of these streams are probably unsuitable for warmouths because their current velocities are greater than warmouths can tolerate. Trautman (1957:49S) reports that in Ohio

The Warmouth Sunfish was most mumerous in lakes, ponds, oxbow's, marshes, and streams of base or very low gradients which had silt-free water, an abundance of aquatic vegetation, and a mucky bottom which was often covered with organic debris. The species was present only in small numbers in weedless oxbows and ponds which had a yellow-silt bottom, and although its colloquial name was "Mud Bass" it seemed to be less tolerant to turbidity and siltation than was the Green Sunfish.

The green sunfish is abundant in creeks and small rivers in cast-central Illinois (Forbes \& Richardson 1920:250; Larimore \& Smith 1963:325). This species is adept at ascending small temporary streams formed by overflow waters from lakes and ponds. Green sunfish are prolific and frequently gain access to a new lake or pond before other species of sunfishes. When this 
occurs, they commonly produce such large populations that the individuals become stunted. Green sunfish are usually unable to compete suceessfully with other speeies of sunfishes which typically inhabit clear-water lakes and ponds. Trautman (1957:50I) stated that the green sunfish is more tolerant of turbidity and siltation than other sunfishes except the orangespotted; however, the largest populations were found in clear-water habitats under conclitions of low competition with other sunfish species.

In east-central Illinois the largest populations of bluegills and red-ear sunfish occur in lakes and ponds which have relatively clear waters. Forbes \& Richardson (1920:25S) found that the bluegill occurred throughout Illinois, but it was generally limited to the larger streams and their principal tributaries and was common in northeastern glacial lakes. During the past 30 years bluegills have been stocked in thousands of lllinois lakes and farm ponds by federal and state agencies (Bennett 1962:104).

In 195 I the Illinois Department of Conservation obtained red-ear sunfish breeding stock from Dr. G. WV. Bennett of the Illinois Natural History Survey. These adult fish were offspring of the red-ear sunfish which were introduced into east-central Illinois from Indiana in 1946 (Lopinot 196I:3). From 195I to 1961 the Illinois Department of Conservation stocked 1,38.3 lakes and ponds with red-ear sunfish, and this species has been widely distributed throughout the state (W. J. Harth, personal communication).

Trautman (1957:5IS) remarked that wherever the red-ear sunfish has been introdueed into waters which are north of its natural range, it has essentially inhabited nonflowing waters which were relatively clear and contained at least some aquatic vegetation. Trautman also stated that at Buckeye Lake, Ohio, the red-car sunfish seemed to re- quire as much as, or more aquatic vegetation than, did the bluegill, and that although both species frequented open water, the recl-ear congregated about brish, stumps, and logs more than the bluegill.

\section{Reproduction}

The reproductive activities of the four kinds of sunfishes were observed over a 7-year period, from $195 \mathrm{~S}$ through 1964, in a number of lakes and ponds within 50 miles of Urbana, Ill. The most frequent observations were made in Big Pond (owned by William Utterback and loeated 5 miles southeast of Gibson City, Ill.) and Lake Italy (owned by the Material Service Corporation and located 3 miles south of Fairmount, Ill.) Big Pond contained bliegill, red-car, and green sunfishes, and Lake ltaly contained all four species.

Tine of SPAwnlvg.-For all four species, males in spawning condition were first collected each year during late April or early May. The first ripe females were collected during the 2 nd or 3rd week of May. The first fish to become ripe were invariably large inclividuals. Ripe inclividuals from stunted populations of bluegills and green sunfish were first collected 2-4 weeks later than from nonstunted populations. Ripe males and females of all four species were collected each month, May through August; lowever, ripe individuals were mueh less abundant during July and August than during May and June. The latest observed fall spawning occurred in Big Pond during the lst week of September, 1960.

Big Pond is naturally divided into three areas which are connected by two short, narrow, shallow cluannels. On August 24, 1960, the three areas were separated by placing heavy canvas barriers across both channels. Two areas were treated with rotenone. On September 5 botll treated areas were inspected to determine if any fish had 


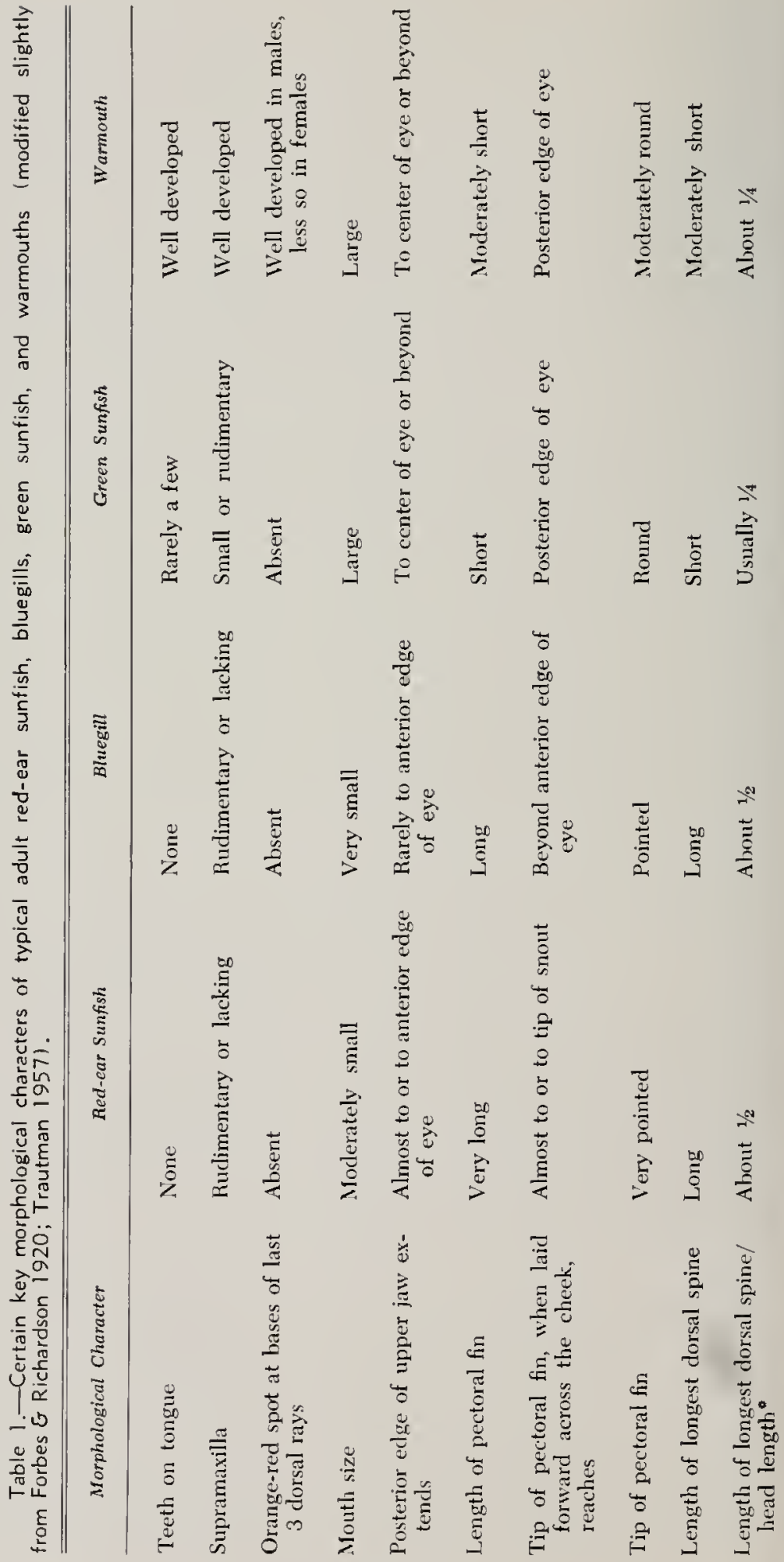




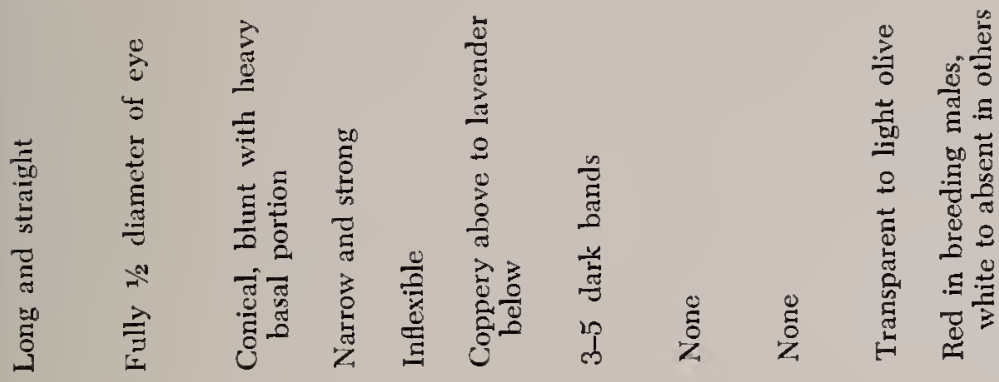

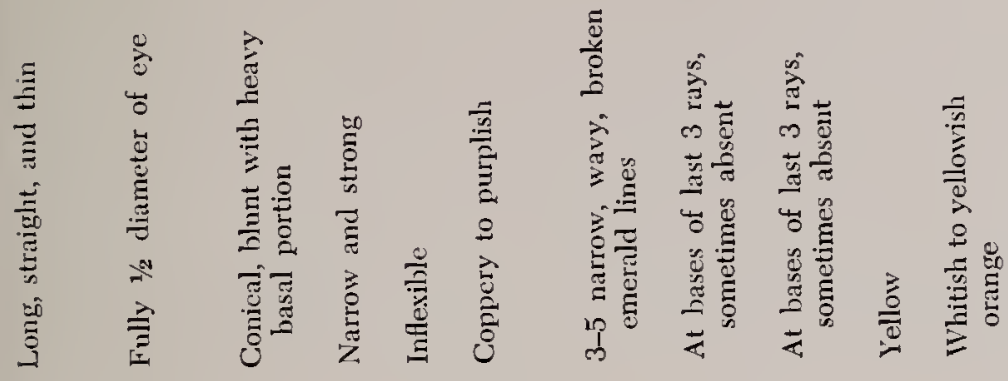

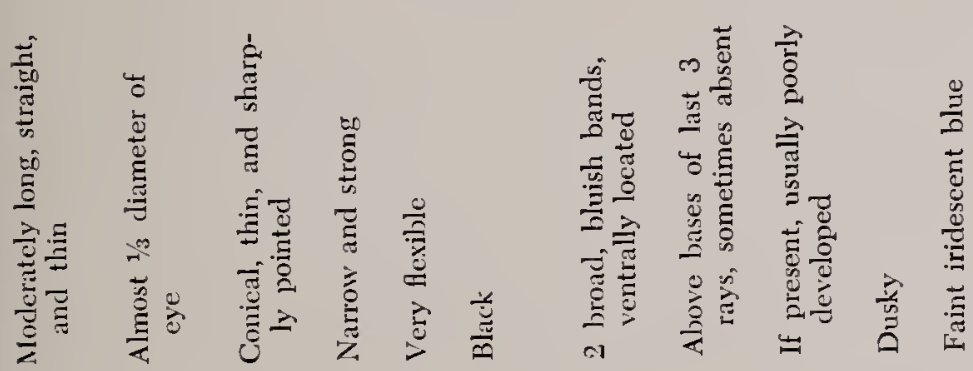

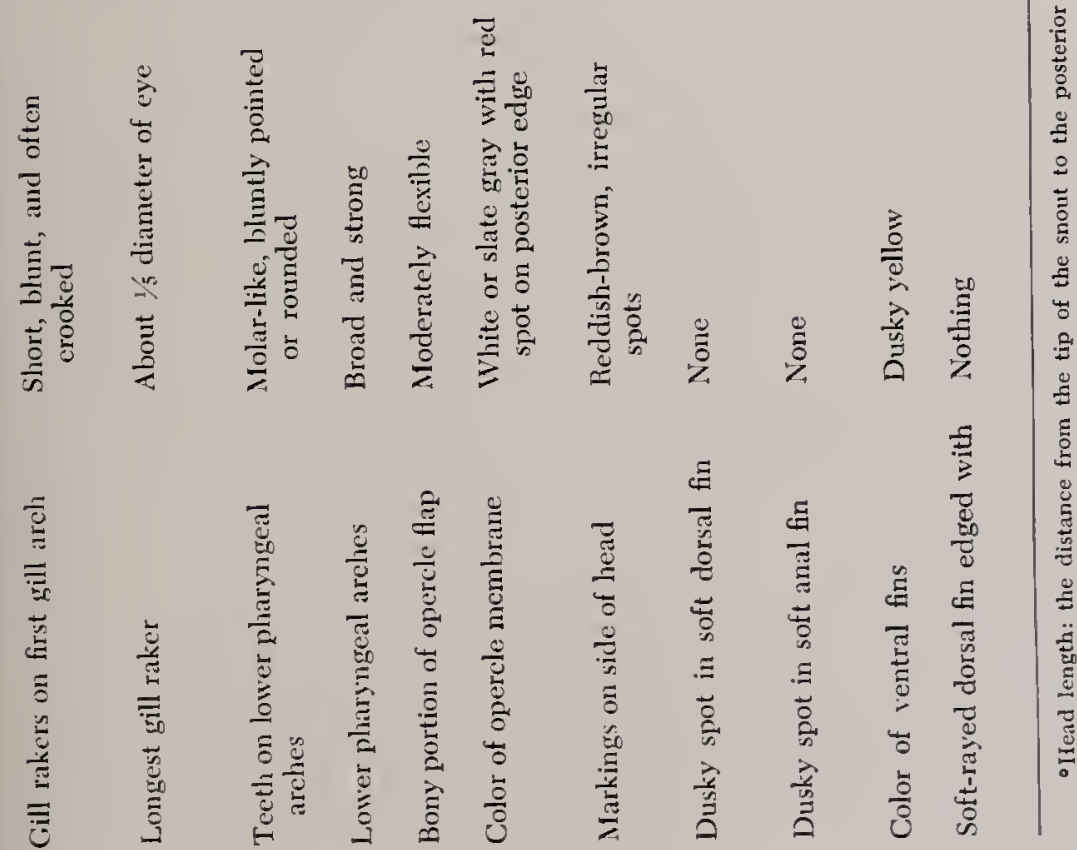


survived the rotenone treatment. The fish kill appeared to be complete in one area, but in the other approximately 30 male bluegills were occupying nests. All nests contained either eggs or larval young. A careful inspection of the untreated area failed to reveal a single nesting sunfish.

Swingle (1956:865) suggestcd that certain species of fishes secrete or excrete a hormone-like substance which acts as a repressive factor and inhibits reproduction in ponds containing dense fish populations. Apparently the rotenone treatment with its resulting drastic reduction of the fish population stimulated the few surviving bluegills to reproduce within about 9-11 days during a period which was somewhat later than their normal spawning season in east-central 1llinois.

In Alabama, red-ear sunfish spawned in the spring when surface water reached a temperature of about $24^{\circ}$ C. $\left(75^{\circ}\right.$ F. $)$, reproduced sparingly or not at all during the summer, and again spawned heavily in the early fall (Swingle 1949:299). I have observed no extensive fall spawning of red-ear sunfish in any east-central Illinois lakes and ponds.

In Fork Lake, Ill., during 1939, the blıcgills of both sexes had gonads in spawning condition during June, July, and August. Males matured earlicr than females and large males became sexually mature earlier than smaller males. Nests were first observed on May 28 when the water temperature at 3 feet was $25^{\circ}$ C. $\left(77^{\circ}\right.$ F. $)$. Occupied nests were last observed on September 18 (Bennett, Thompson, \& Parr 1940:17 $18)$.

In the Gardner Ponds at the University of Wisconsin Arboretum the spawning season of green sunfish commenced in late May or early June when the water temperature reachcd about $21^{\circ}$ C. $\left(70^{\circ}\right.$ F. $)$, continued through June and July, and terminated in carly August. Apparently larger males spawned earlier and more frequently than smaller males (Hunter 1963: 16-18).

In Park Pond, Vermilion County, Ill. warmouth spawning was initiated during the 2nd week in May, 1949, when the water tempcrature at 12 inches was approximately $21^{\circ}$ C. $\left(70^{\circ}\right.$ F. $)$. Gonadal weight-body weight ratios indicated that most spawning was completed by early July. Warmouths of less than $89 \mathrm{~mm}$ (3.5 inches) total length failed to spawn. Males ripcned earlier in the season than females and large fish spawned earlier than smaller ones (Larimore 1957:31-35).

Location of Nests.-The first evidence of reproductive activity in the spring was the movement of males into shallow water. As the length of the photoperiod and the temperature of the water increased, males constructed nests (saucer-shaped depressions in the substrate) which they defended with great vigor.

All four species usually nested in areas where the water was less than 3 feet deep. Red-ear sunfish, bluegills, and grcen sunfish normally nested in colonies, on firm substrates, and often in locations exposed to the sun. WVarmouths were more solitary in their nest site selections. They frequently nested on soft substrates even when firm substrates were available. Larimore (1957:40) reported that warmouths were not as consistent in selecting a particular type of substrate as they were in selecting a spot near a stump, rock, root, clump of vegetation, or some similar olject, and that nests were never found on an area of bottom completely exposed, such as was usually chosen by the blucgill.

In Utterback's Big Pond and Lake Italy, red-ear sunfish males and bluegill males were frequently found nesting together in the same colony. Green sunfish males were less commonly found nesting with males of the other spccies; however, this difference may 
have been related to the smaller numbers of green sunfish in both bodies of water. Warmouth males were never observed nesting in colonies. In colonies of nests occupied by more than one species, males of the minority species formed a subcolony within the larger group.

SPaWNivg AND CaRe of Young.In general the four species are remarkably similar in their spawning and parental behavior. During spawning a pair slowly swims side by side in tight circles over the male's nest. Fertilization is external and the demersal eggs adbere to the material forming the bottom of the nest. After spawning, the female leaves or is driven from the nest by the male, and the male fans the eggs and larval young until they become free-swimming fry. During fanning, the male hovers over the nest while undulating his body in such a way that currents of water are directed downward into the nest. Fanning can best be described as stationary swimming. The water currents thus produced are probably important in cleansing and oxygenating the developing embryos. During this period, the male also proteets the eggs and young and will viciously attack predators much larger than himself.

Duration of Fertility of Gametes. -Since three of the four species selected for study sometimes nest in mixed colonies, the functional life spans of gametes could be very important in controlling hybridization between these species. If gametes are capable of fertilizing and being fertilized over long periods of time, sperm driftage could result in the production of hybrid individuals. Experiments were conducted to detcrmine the functional life spans of bluegill, green sunfish, and warmouth gametes. In one set of experiments, both sperm and eggs were aged for various periods of time prior to fertilization; in another group of experiments only eggs were aged.
Ripe male and female bluegills, green sunfish, and warmoutlis were captured by seining and trapping in local ponds. ${ }^{1}$ These fish were moved into the laboratory and separated in aquaria according to species and sex. Fish were held in these aquaria for one-half hour to 2 hours before gametes were stripped from them. Care was taken to avoid any temperature shock to the fish prior to their use in the experiments.

In the experiments in which both sperm and eggs were aged prior to fertilization, the method was: Five clean glass petri dishes were individually numbered from 1 to 5 . Each dish was then partially filled by adding $20 \mathrm{ml}$ of water. All of the water used in these experiments was obtained from the well on Parkhill's Lake Park Subdivision Number Two. The water was moved into the Illinois Natural History Survey laboratory and stored in a 210 gallon aquarium. It was aerated and filtered through aetivitated charcoal for at least 1 week prior to its use. A partial chemical analysis of this water is presented in Table $A l$ in the appendix.

Starting with dish 1 and ending with dish 5 , eggs from a ripe female warmouth were stripped into each of the five dishes. Immediately after eggs were stripped into a dish, the dish was gently shaken to scatter the eggs over the bottom. Eggs were stripped into consecutive dishes at approximately 7-second intervals, and so the entire egg-stripping process was completed in about 30 seconds. During the next 15 seeonds, one-half $\mathrm{ml}$ of seminal fluid was stripped from a ripe male warmouth and diluted with $10 \mathrm{ml}$ of water. One $\mathrm{ml}$ of this solution was then added to the water and eggs in dish 1 , and to the

${ }^{1}$ All sunfishes used in these experiments were obtained from these Illinois ponds: bluegills and green sunfish from Pifers Pond, about 3 miles southeast of Sullivan, and Utterback's Big Pnnd, 5 miles southeast of Gibson City: hlucuills from Redhead's Pnnd, 4 miles east of lioner; warmouths and green sunfish frnm Lake of the Wonds, I miles northeast of Mahomet; warmnuths from Taylor's Pond, 3 miles southwest of Fairmount. 
other dishes in sequence after intervals of $2.5,5.0,7.5$, and 10.0 minutes. From 5 to 10 minutes after the gametes were mixed in each dish, the zygotes were washed tluree times (by decanting and refilling each dish with clean water) and then enough water was added to each dish to cover the eggs.

Water in each dish was changed several times during incubation, and dead eggs and embryos were removed. Newly hatched larvae were transferred to clean, numbercd dishes. The number of eggs in each dish at time of fertilization, the number of eggs which hatched, and the number of larvae which developed into normal-appearing swim-up fry were recorded. The incubation temperature was recorded with an air thermograph located directly alongside the petri dishes.

The same procedure was followed in measuring the functional life spans of bluegill and green sunfish sperm and eggs, except that six egg samples were stripped from each fcmale and the time interval separating the mixing of gametes in the sequence of dishes was 1.0 minute instead of 2.5 minutes.

In the second group of experiments only the eggs of the three species were aged prior to fertilization. The procedure of the first group of experiments was used, except that two drops of undiluted seminal fluid were stripped directly on the eggs after they had been aged for $0.5,30.0,60.0,120.0$, and 180.0 minutes.

The results of individual experiments concerning the functional life spans of activated gametes of blnegills, green sunfish, and warmoutlıs are presented in Tables A2-A13 of the appendix. Data from experiments for each species were pooled and are presented in Tables 2-4.

Under the conditions of these experiments "average functional lives" (length of time gametes were aged that resulted in a 50-percent reduction in fry viability) of warmouth, bluegill, and green sunfish eggs wcre interpolated to be 94,60 , and 47 minutes, respectively. Specific differences may have been the result of variation in the physiological state of the mature eggs and the exposure of the various samples to uncontrollable environmental differences.

All of the eggs in an individual exper-

Table 2.-Duration of fertility of activated warmouth gametes. Data from experiments WI-W4 are combined.

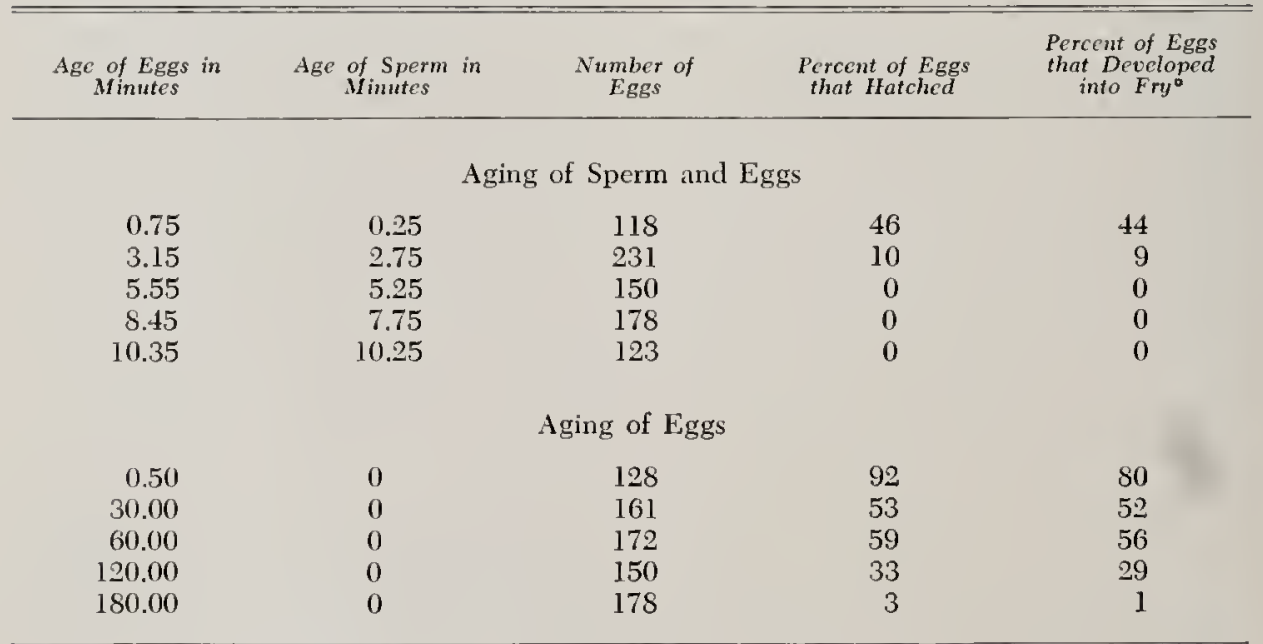

-Fry able to swim for short periods but not completely free swimming. Only normal fry are included in this figure. 
Table 3.-Duration of fertility of activated bluegill gametes. Data from experiments B 1-B4 are combined.

\begin{tabular}{|c|c|c|c|c|}
\hline $\begin{array}{c}\text { Age of Eggs in } \\
\text { Minutes }\end{array}$ & $\begin{array}{c}\text { Age of Sperm in } \\
\text { Minutes }\end{array}$ & $\begin{array}{c}\text { Number of } \\
\text { Eggs }\end{array}$ & $\begin{array}{l}\text { Percent of Eggs } \\
\text { that Hatched }\end{array}$ & $\begin{array}{l}\text { Percent of Eggs } \\
\text { that Developed } \\
\text { into Fryo }\end{array}$ \\
\hline \multicolumn{5}{|c|}{ Aging of Sperm and Eggs } \\
\hline 1.00 & 0.25 & 92 & 65 & 48 \\
\hline 1.90 & 1.25 & 74 & 49 & 24 \\
\hline 2.80 & 2.25 & 76 & 12 & 12 \\
\hline 3.70 & 3.25 & 85 & 1 & 1 \\
\hline 4.60 & 4.25 & 65 & 0 & 0 \\
\hline 5.50 & 5.25 & 64 & 0 & 0 \\
\hline \multicolumn{5}{|c|}{ Aging of Eggs } \\
\hline 0.50 & 0 & 210 & 81 & 80 \\
\hline 30.00 & 0 & 143 & 69 & 67 \\
\hline 60.00 & 0 & 123 & 42 & 40 \\
\hline 120.00 & 0 & 196 & 19 & 16 \\
\hline 180.00 & 0 & 124 & 9 & 7 \\
\hline
\end{tabular}

- Fry able to swim for short periods but not completely free swimming. Only normal fry are included in this figure.

Table 4.-Duration of fertility of activated green sunfish gametes. Data from experiments Gl-G4 are combined.

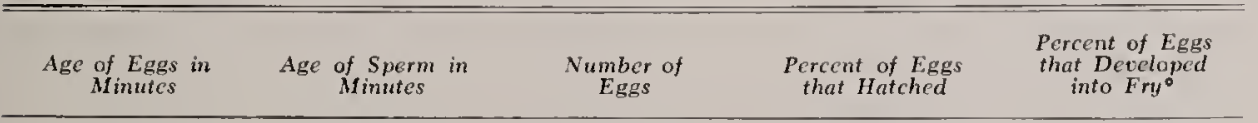

Aging of Sperm and Eggs

$\begin{array}{lrrrr}1.00-2.25 & 0.25 & 163 & 48 & 44 \\ 1.90-3.15 & 1.25 & 141 & 18 & 18 \\ 2.80-4.05 & 2.25 & 105 & 3 & 3 \\ 3.70-4.95 & 3.25 & 223 & 3 & 2 \\ 4.60-5.85 & 4.25 & 139 & 1 & 1 \\ 5.50-6.75 & 5.25 & 158 & 2 & 2\end{array}$

Aging of Eggs

$\begin{array}{rllll}0.50 & 0 & 141 & 58 & 57 \\ 30.00 & 0 & 222 & 39 & 37 \\ 60.00 & 0 & 216 & 23 & 21 \\ 120.00 & 0 & 152 & 20 & 18 \\ 180.00 & 0 & 171 & 13 & 12\end{array}$

-Fry able to swim for short periods but nct completely free swimming. Only normal fry are included in this figure.

iment were from a single female; however, eggs from one female may vary in their physiological response to fertilization. The first eggs to flow often appcared to be more nearly ripe than those which followed. Consequently if eggs from a female were slightly green. serial samples of her eggs would exhibit a decrease in the percentage hatching, but if her eggs were slightly past optimum ripeness, serial samples might increase in hatchability. Even though dead zygotes were removed and the water in the dishes was ehanged at frequent intervals during each experiment, carbon dioxide and dissolved 
oxygen tensions were probably variable and more critical in clishes where mortality was ligh. Chance contamination of some samples by bacteria and protozoans also may have resulted in environmental differences in various samples.

The average functional life spans of sperm (based on the age of the sperm in the experiments in which both eggs and sperm were aged) from warmouths, green sunfish, and bluegills were interpolated to be $1.1,1.0$, and 1.0 minutcs, respectively. Specific differences in the results of these experiments were probably not valid because of the factors previously described.

The average functional life span of eggs from the three species was 67 minutes, and for sperm it was 1 minute. Functional life spans of gametes from red-ear sunfish were not investigated; however, they are probably similar to those of warmouths, bluegills, and green sunfish.

The brief fumctional life spans of the spermatozoans of these species are $\mathbf{m}$ doubtedly very important in redueing lybridization caused by sperm drifting from nest to nest.

\section{HYBRIDIZATION EXPERIMENTS}

Two types of experiments were used to produce lybbrid sunfishes. In the first, referred to as "stripping experiments," gametes were stripped from ripe adults and manually mixed. With this method it was possible to determine species isolation due to ineompatibilities between sperm and eggs (primary genetic isolation). In the second type, designated "isolation experinents," one or more pairs of fish composed of a male of one species and a female of another were isolated in small ponds to determine if they would hybridize when mates of their own species were absent.

In this paper $R$ refers to red-ear sunfish, B to hluegill, G to grcen sunfish, and $\mathrm{IV}^{\top}$ to warmontin. Matings hetween individuals of different species are designated as $P_{1}$ crosses, and the resultant hybrids are designated as $\mathrm{F}_{1}$ hybrids. $F_{2}$ hybrids are those produced by mating an $F_{1}$ male with an $F_{1}$ female. The male parent species is always given first; thus, the $P_{1}$ cross of a male bluegill and a female green sunfish is designated $B \times G$ and the resultant hybrids are designated $B G F_{1}$ hybrids; $G B F_{1}$ designates the reciprocal hybrids.

\section{Stripping Experiments}

Sperm and eggs stripped from the four parent species were paired in 16 different combinations to produce $z y$ gotes representing the four parent species and 12 hybrids. These expcriments were clesigned to allow comparisons of rates of embryological development and the cxtent of viability of $F_{1}$ hybrids and their maternal parent speeies.

Methons and MaterLals.-Ripe males and females of the four species were brought into the laboratory from nine local ponds. Laboratory treatment of these fish was the same as for those used in experiments concenned with functional life spans of gametes.

A ripe female of onc of the four species and one ripe male of each of the four specics were used in each experiment. No individual fish was used more than once. Fish selected for an experiment were individually isolated for at least 30 minutes before gametes were stripped, and the person doing the stripping rinsed and dried his hands after handling each fish.

Twelve clean petri dishes were individually marked and $20 \mathrm{ml}$ of aged, filtered well water were added to each dish. A sample of eggs from one ripe female was stripped into each of the 12 petri dishes, and the eggs were seattered by gently shaking the dishes. Two drops of milt were then stripped into each dish. Milt from one male of each of the four species was used to fertilize the eggs in three dishes. An entire stripping program for the five fish was completed in less than 5 minutes. Approximately 10 minutes after the stripping was completed, the zygotes were 
washed three times by decanting and refilling each dish with clean water. During incubation the amount of water in each dish was regulated so that the developing embryos were always covered with a thin layer $(2-8 \mathrm{~mm}$ ) of water.

Dead embryos were removed, and the water covering the living embryos was changed several times during each experiment. The frequency with which dead embryos were removed and water was changed was varied according to the incubation temperature. In the experiments with the highest $\left(28.6^{\circ} \mathrm{C}\right.$.) and the lowest (22.3 $3^{\circ}$ C.) mean incubation temperatures the intervals were approximately 5 and 24 hours, respectively. Larvae were transferred to clean, numbered dishes within 1 hour after hatching.

An air thermograph was used to record temperatures adjacent to the dishes containing the embryos. The maximum range of fluctuation of air temperature during any one experiment was $3^{\circ} \mathrm{C}$. Hourly air temperature fluctuations never exceeded $0.7^{\circ}$ C. Since the petri dishes contained relatively small amounts of water and since air temperature fluctuations were slight, water temperatures were considered to be the same as air temperatures in these experiments. Records were made of the number of eggs in each dish at the time sperm and eggs were mixed, the number of eggs that hatched each hour, and the number of larvale that developed into morphologically normal-appearing swim-up fry. Upon termination of each experiment, all living fry were killed with a 4-percent aqueous solution of formaldehyde and stored in a 1-percent solution. Total body lengths of 25 morphologically normal-appearing fry of each kind of viable fry from each experiment were measured to the nearest $0.03 \mathrm{~mm}$ with an ocular micrometer.

A total of 11 stripping experiments was conducted: Eggs from three redear sunfish, three bluegills, three green sunfish, and two warmouths were fertilized with sperm from males of all four species. The temperatures at which these experiments were conducted were well within the range of temperatures that embryos of the four species are subjected to under natural conditions. Nine of the experiments were terminated when the zygotes developed into swim-up fry. The other two experiments, both of which were conducted with red-ear sunfish eggs, were terminated shortly after the fry became free swimming.

Results and Discussion:-The percentages of eggs that latched and the percentages of eggs that developed into morphologically normal-appearing fry were calculated for each of the 132 samples of the 11 experiments (Tables Al4-A24 of the appendix). These porcentages were transformed into degrces of a right angle to minimize bias inherent in using weighted percentages in an analysis of variance (Fisher \& Yates 1963:74-75). A 7094 digital computer was used in analyzing these clata. Data from the 11 stripping experiments were condensed and are presented in Tables 5-S.

Preliminary tests revealed that high percentages of eggs hatched in some petri dishes containing as many as 500 eggs; however, mortality was higher in dishes containing 400-500 eggs than in dishes containing 200-300 eggs. Since the number of eggs per sample was a variable in these experiments, the number was purposely kept low (mean number of eggs per sample was 65) to minimize the effect of crowding. An analysis of variance revealed that there was no significant correlation between the number of eggs per sample and the percentage that hatched. Conserplently, the number of eggs per sample was used as a statistical weight in the anal$y$ sis of the viabilities of the 16 different kinds of zygotes.

Data from the 11 stripping experiments pertaining to the percentages of eggs that hatched and the percentages 


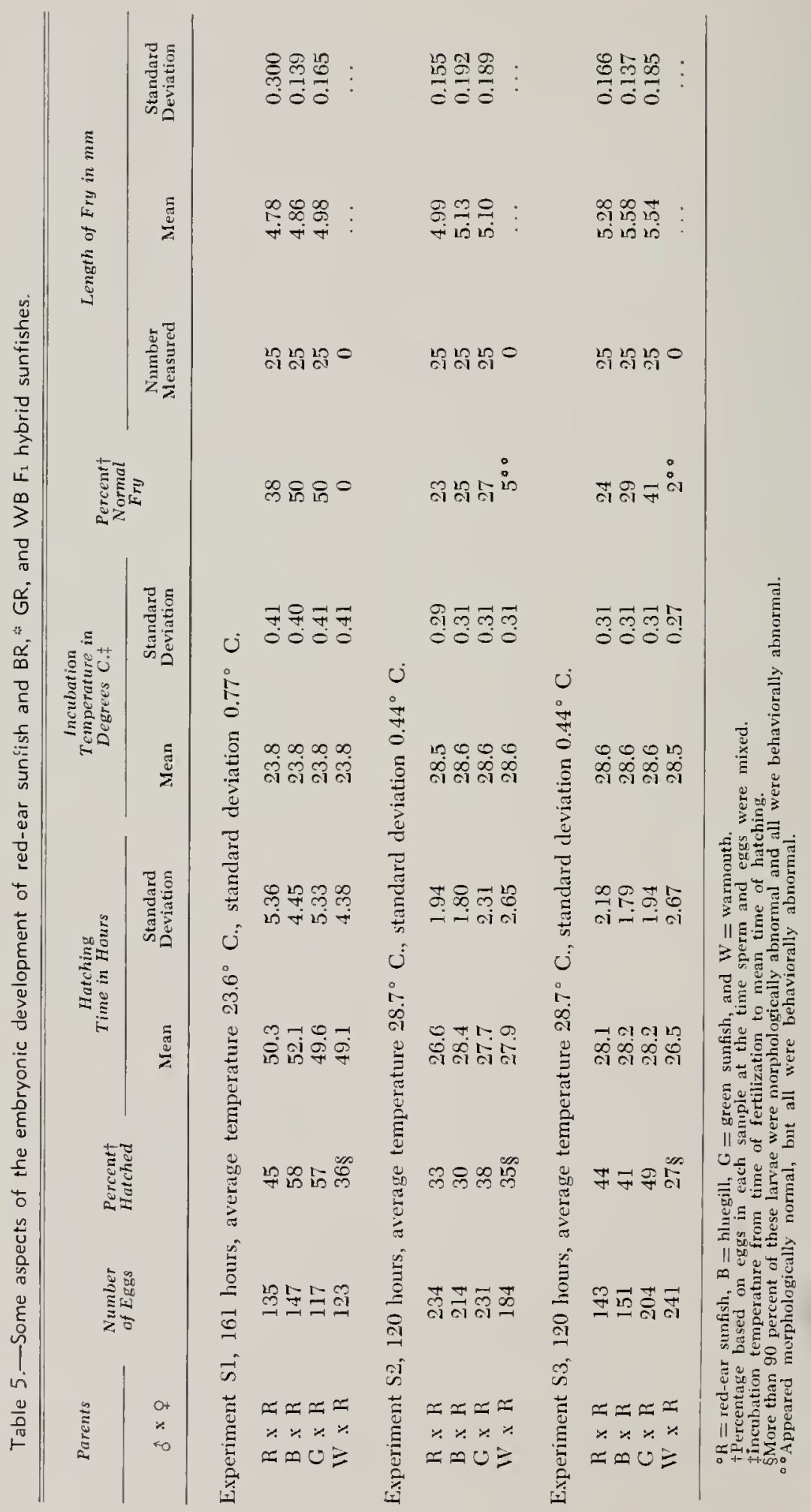




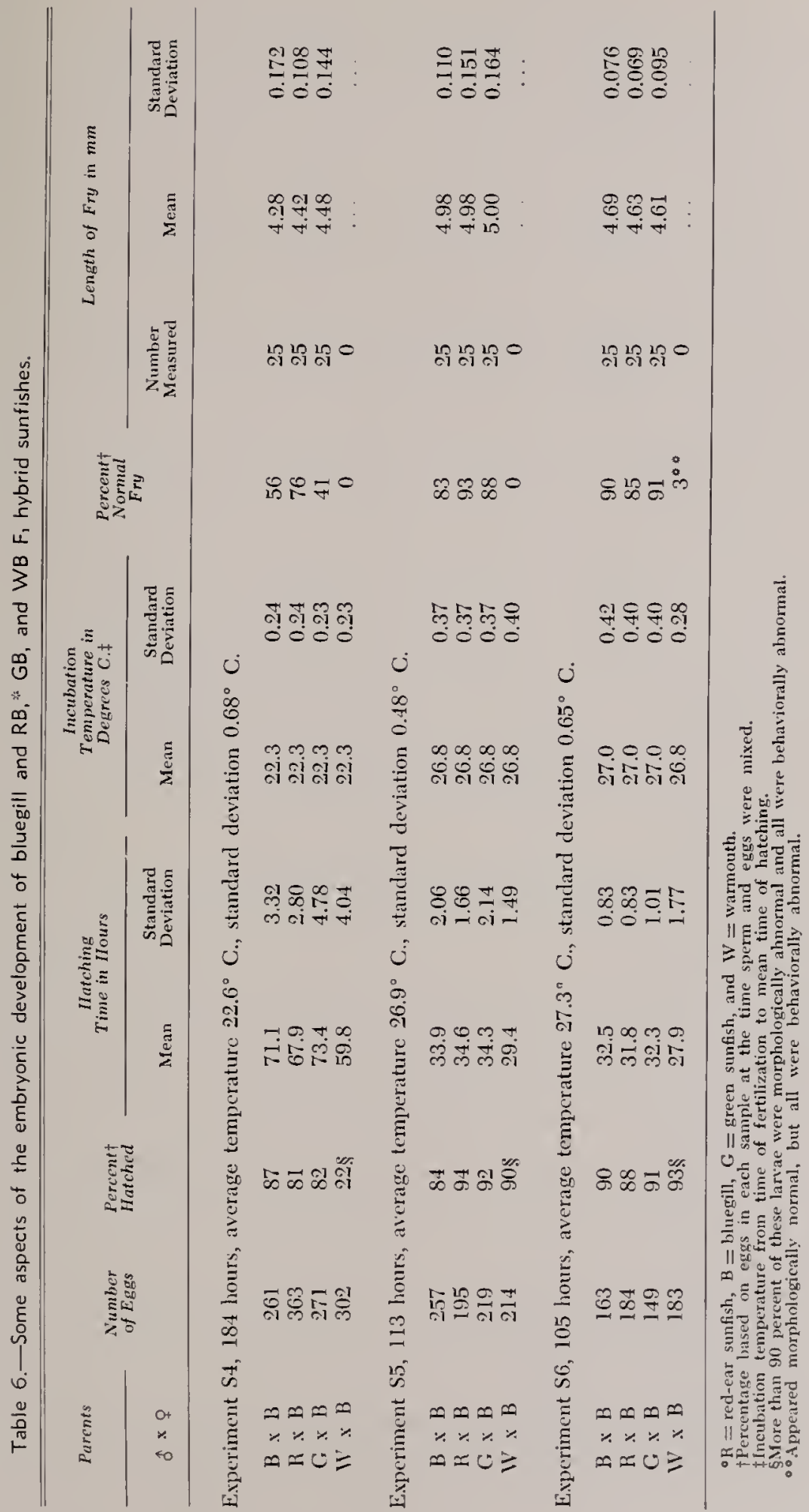




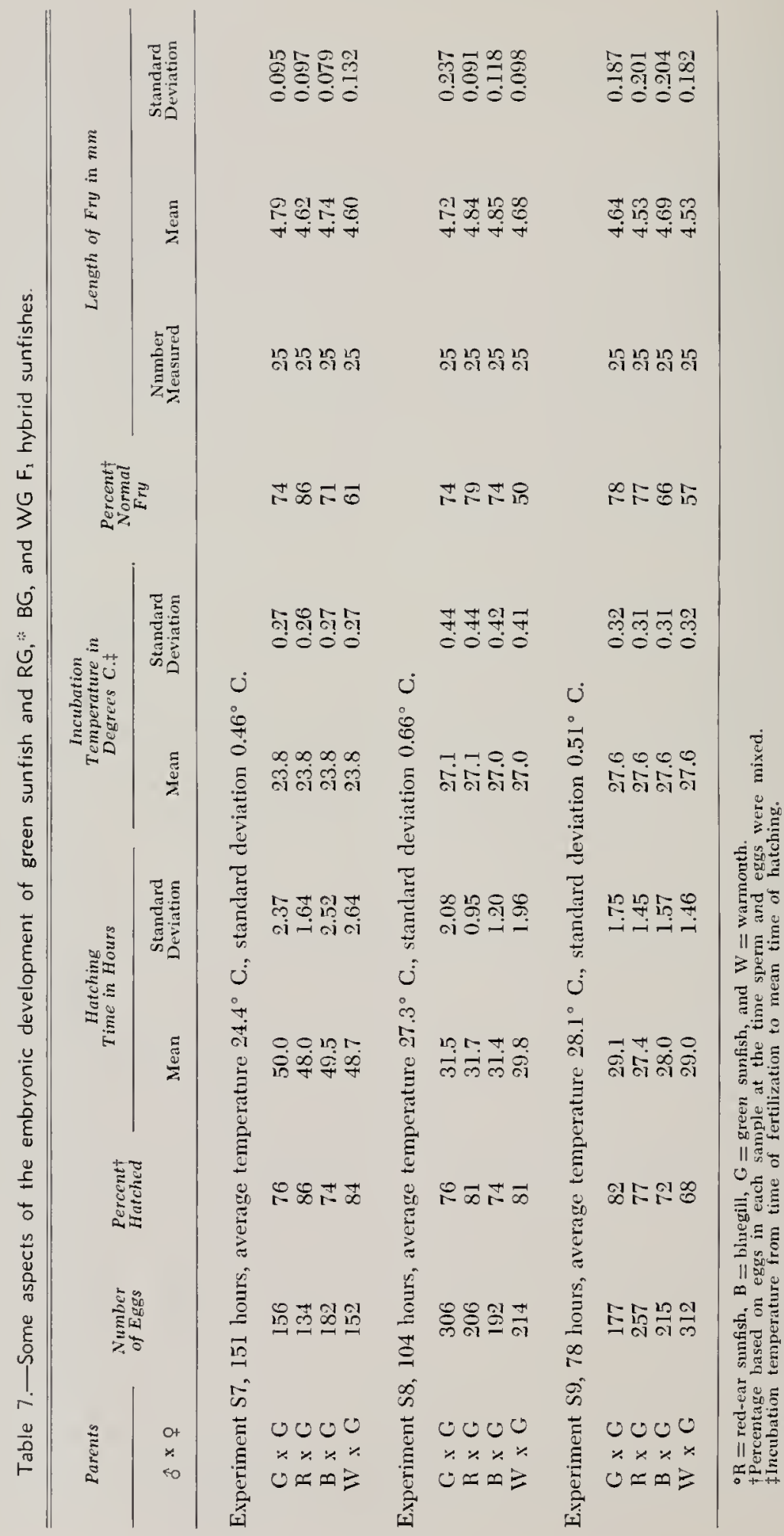




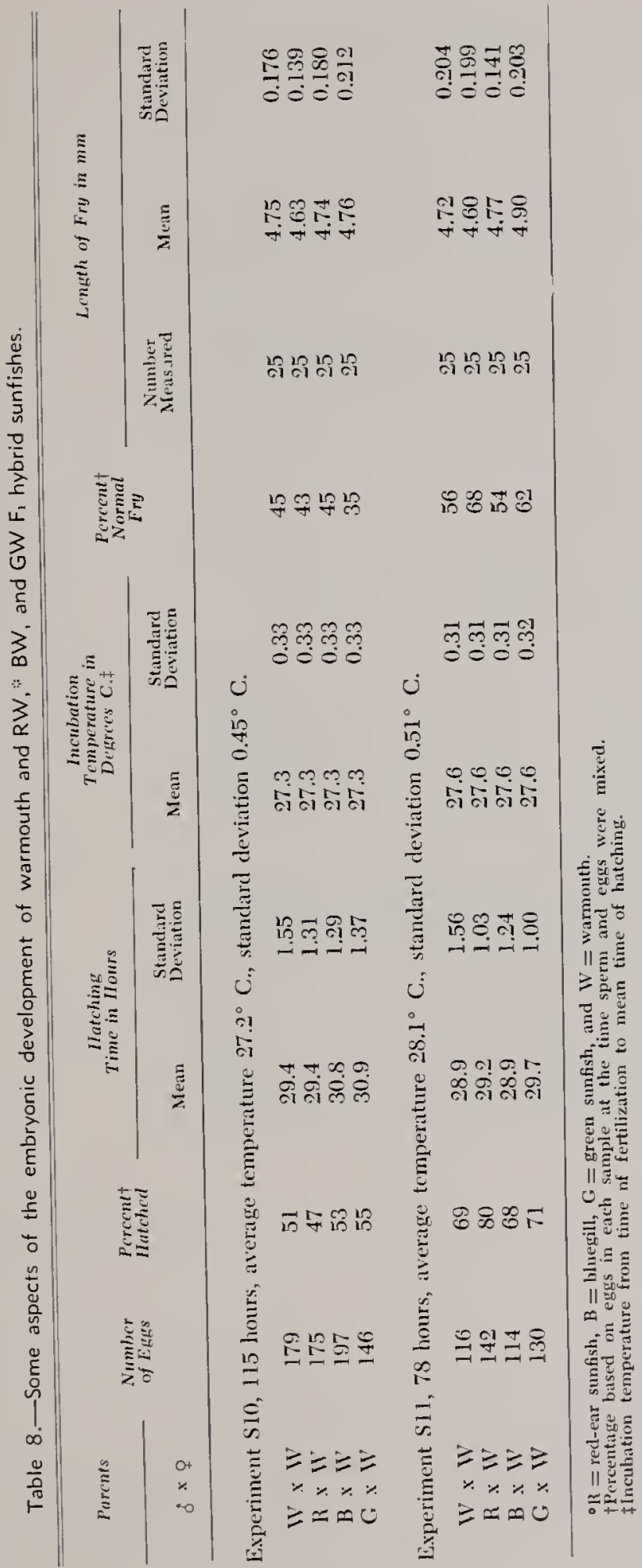


of eggs that developed into morphologically normal-appearing fry were combined and are presented in Table 9. The percentages of laatched zygotes of the four pure species were compared with one another. Statistically, the hatching success of red-ear sunfish zygotes (39 percent) was significantly less $(0.01$ level) than that of warmouth ( $5 \mathrm{~S}$ percent), green sunfish ( $7 \mathrm{~S}$ pereent), and bluegill zygotes ( 87 percent). The warmouth hatching percentage was significantly less than those of the green sunfish (0.05 level) and the blucgill ( 0.01 level). The hatching success of green sumfish zygotes was not significantly different from that of blucgill zygotes. These differences are not believed to represent valid differences between the hatchabilities of eggs of the four species, but are probably the result of differences in the maturity of eggs from the females used in these experiments. Consequently, to minimize such differences, the percentage of eggs that hatehed and the pcrcentage of normal-appearing fry of each liybrid type were compared with those of its maternal parent species.

No hybrid type was significantly different from its maternal parent species in the percentage of zygotes that hatched; however, more than 90 percent of the IVR and IVB $F_{1}$ hybrids were morphologically abnomal (Fig. 1 and 2 ).

Both IVR and IVB $F_{1}$ hybrids exhibited high mortality between the hatching and swim-up fry stages. At the time the experiments were terminated, only 2 percent of the WR hybrids and 1 percent of the IVB hybrids appeared to be morphologically normal. All of these morphologically normalappearing $W R$ and $W V B F_{1}$ hybrid fry were very sluggish. When petri dishes containing these hybrid fry were tapped with a pencil, the fry responded with weak swimming movements or not at all, and it is very doubtful that

Table 9.- The degree of viability of 16 different kinds of fishes produced by pairing gametes from red-ear sunfish, bluegills, green sunfish, and warmouths. Data from experiments SI-SII are combined.

\begin{tabular}{|c|c|c|c|}
\hline Parent Species ${ }^{\circ}$ & \multirow{2}{*}{$\begin{array}{l}\text { Number } \\
\text { of Eggs }\end{array}$} & \multirow{2}{*}{$\begin{array}{l}\text { Percent } \\
\text { Ilatehed }\end{array}$} & \multirow{2}{*}{$\begin{array}{c}\text { Percent } \\
\text { Normal Fry }\end{array}$} \\
\hline$\hat{o} \times q$ & & & \\
\hline$R \times R$ & 512 & 39 & 27 \\
\hline$B \times R$ & 512 & 41 & 33 \\
\hline$G \times R$ & 552 & 46 & 37 \\
\hline$W \times R$ & 548 & $32 \S$ & $2^{\circ \circ}$ \\
\hline$B \times B$ & 681 & 87 & 75 \\
\hline$R \times B$ & 742 & 86 & 83 \\
\hline $\mathrm{C} \times \mathrm{B}$ & 639 & 87 & 69 \\
\hline$W \times B$ & 699 & $61 \S$ & $1^{\circ 0}$ \\
\hline$G \times G$ & 639 & 78 & 75 \\
\hline$R \times C$ & 597 & 80 & 79 \\
\hline$B \times G$ & 589 & 73 & 70 \\
\hline W $\times C$ & 678 & 76 & 55 \\
\hline$W \times 1 V$ & 295 & 58 & 49 \\
\hline $\mathrm{R} \times \mathrm{WV}$ & 317 & 62 & 58 \\
\hline$B \times I V$ & 311 & 58 & 44 \\
\hline$G \times W$ & 276 & 62 & 47 \\
\hline
\end{tabular}

${ }^{\circ} \mathrm{R}=$ red-ear sunfish, $\mathrm{B}=$ bluegill, $\mathrm{G}=$ green sunfish, $\mathrm{W}=$ warmouth.

Percentage based on number of eggs at the time sperm and egus were mixed together and the number that totched.

$\mp$ Percentage based on number of eggs at the time sperm and eggs were mixed together and the number of miphologically normal-appearing fry.

§IIore than 90 percent of these lavae were morphologically deformed.

o These fry appeared morphologically normal, but all were behaviorally abnormal. 
Fig. 1.-Red-ear sunfish fry (above) and WR $F_{1}$ hybrid fry (below) selected to show the range of morphological deformities of the hybrid fry. All fry were produced from eggs from one female red-ear sunfish. Both kinds of zygotes were allowed to develop simultaneously under similar conditions for 120 hours before being sacrificed. The mean hourly temperature was $28.7^{\circ} \mathrm{C} .\left(83.6^{\circ} \mathrm{F}.\right)$, standard deviation, $0.44^{\circ} \mathrm{C}$. $\left(0.79^{\circ} \mathrm{F}.\right)$
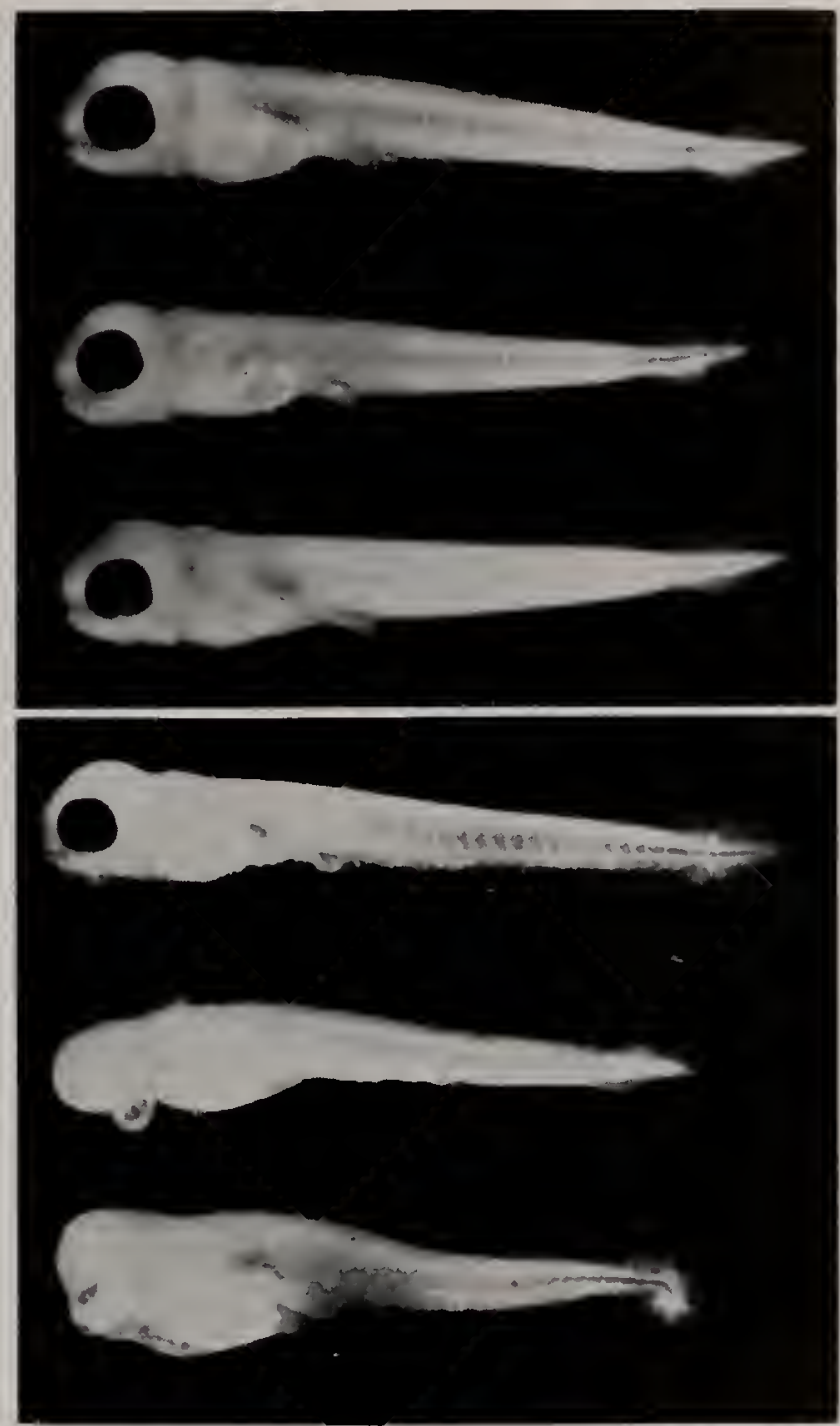

any of these fry would have become free swimming. Fifty-five percent of the WG hybrid and 75 percent of the pure green sunfish zygotes developed into normal-appearing swim-up fry (difference significant to 0.05 level). The WG liybrid swim-ip fry appeared to be behaviorally normal. The remaining nine kinds of hybrids were not significantly different from their maternal parent species in the percentages that developed into normal swim-up fry.

The mean hatcling time and stand- ard deviation were calculated for each of the 132 samples of eggs in the 11 experiments (Tables A14-A24 of the appendix). A statistical weight was calculated for the mean hatching time of each sample by dividing the number of eggs that batebed by the variance of the mean hatching time. A 7094 digital computer was used in the analysis of variance of these data.

The statistical analysis, in which the weighted mean hatching time of eacl, kind of hybrid was compared with that 
Fig. 2. - Bluegill fry (above) and WB $F_{1}$ hybrid fry (below) selected to show the range of morphological deformities of the hybrid fry. All fry were produced from eggs from one female bluegill. Both kinds of $z y$ gotes were allowed to develop simultaneously under similar conditions for 113 hours before being sacrificed. The mean hourly temperature was $26.9^{\circ} \mathrm{C}$. $180.4^{\circ}$ F.). standard deviaticn, $0.48^{\circ} \mathrm{C} .\left(0.86^{\circ} \mathrm{F}.\right)$
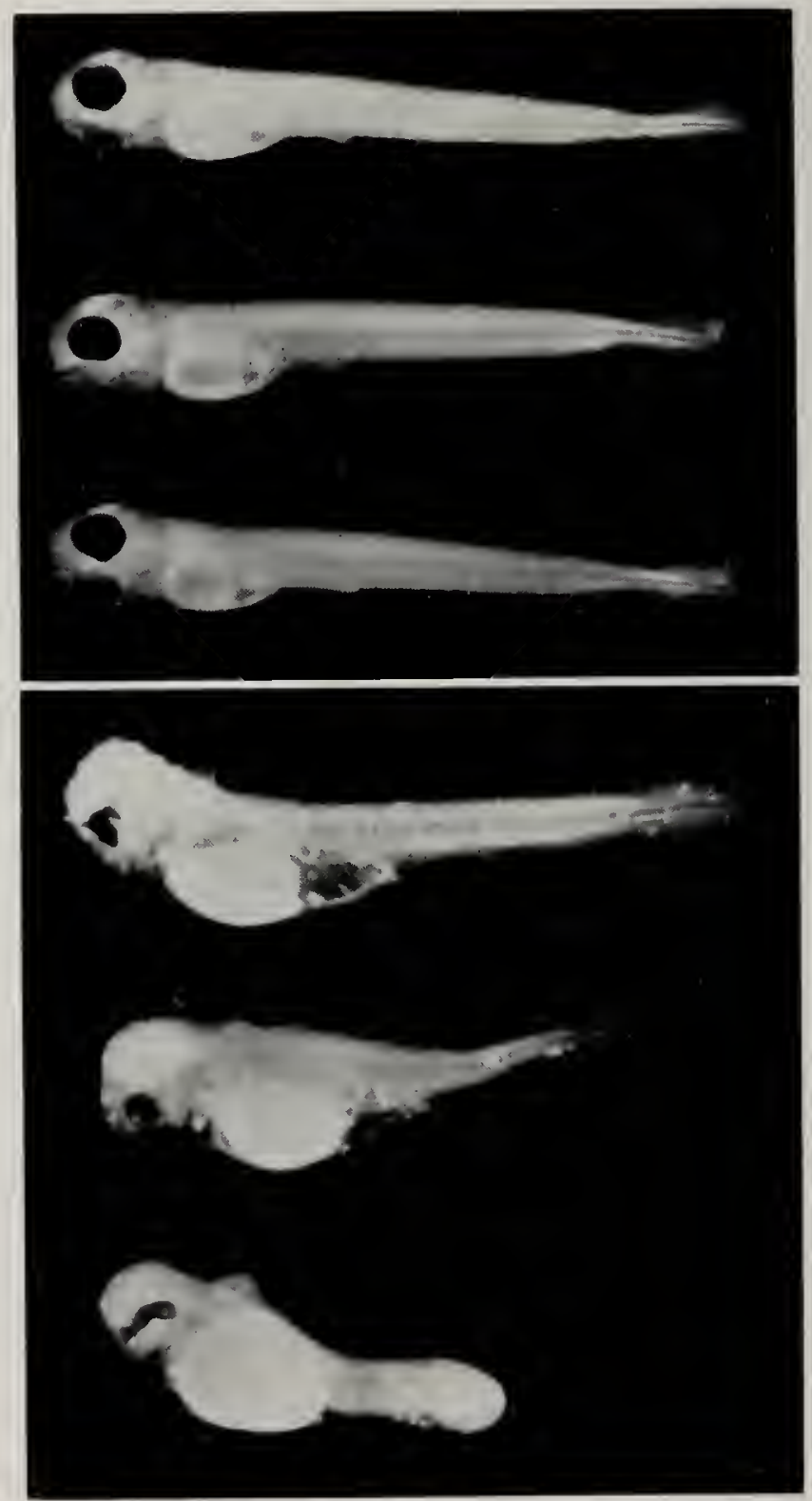

of its maternal parent species, revealed that WVB $F_{1}$ hybrid zygotes hatehed significantly sooner than pure bluegill zygotes when both kinds of zygotes were incubated at the same temperatures. Although WVB zygotes hatched in less time, the newly emerged IVB $\mathrm{F}_{1}$ larvae were not as advanced in their development as the unhatched pure bluegill embryos. WR $F_{1}$ hybrids were not significantly different from pure red-ears in hatching time; however, the newly emerged IVR larvae were not as advanced in their development as the pme red-ear larvae. There were no statistically significant differences in the time of hatching between the other 10 kinds of hybrids and their respective 
maternal parent species, and differences in the degree of development between the hybrids and their respeetive maternal parent species were not pronounced.

The meam body length and standard deviation were calculated for each kind of viable fry from each experiment (Tables 5-8). An analysis of variance in which the mean body length of each kind of viable hybrid fry was compared to that of its maternal parent speeies revealed that $\mathrm{BR}$ and $\mathrm{GR}$ were significantly ( 0.05 level of probability) longer bodied than the pure red-ear fry. The other eight kinds of hybrids were not significantly different from their respective maternal parent species fry in total body length.

The alpha temperature threshold of development (Shelford 1927:357) and the mean number of developmental units (degree-hours of effective temperature) necessary for 50-percent hatching were calculated for each of the 16 kinds of zygotes. The statistical method was designed by Dr. H. WV. Norton $^{1}$ to determine the linear correlation of two variables ( $T$ and $R$ ) when both variables are subject to error.

Given: Equation I

$$
(\mathrm{T}-\mathrm{A}) \mathbf{t}=\mathrm{U}
$$

where

$\mathrm{T}=$ mean hourly incubation temperature

$\mathrm{A}=$ alpha threshold of development

$t=$ mean hours of incubation necessary for 50-percent hatching

$\mathrm{U}=$ number of developmental units necessary for 50-percent hatching

Then: Equation II

$$
\mathrm{A}=\frac{\left(\mathrm{W}+\mathrm{V} / \mathrm{U}^{2}\right)(\mathrm{T}-\mathrm{UR})}{\left(\mathrm{W}+\mathrm{V} / \mathrm{U}^{2}\right)}
$$

'Professor of Statistical Design and Analysis, Animal Science Department, University of Illinois, Urbana. where

$$
\mathrm{W}=4
$$

(estimated on the basis of the accuracy with which the thermograph could he adjusted and read)

$$
\mathrm{V}=\frac{3 \mathrm{n}_{\mathrm{r}} \mathrm{t}^{\mathrm{t}}}{\mathrm{nv_{ \textrm {b } }}+3 \mathrm{v}_{\mathrm{w}}}
$$

(three times the number of zygotes which hatched, times the fourth power of the mean hours of incubation, divided by the number which hatehed, times the pooled between variance of the hatching times, plus three times the within variance of the hatching times )

$$
\mathrm{R}=1 / \mathrm{t}
$$

(reciprocal of the mean hours of incubation)

Then: Equation III

$$
\begin{aligned}
& 2\left[\left(\mathrm{~W}+\mathrm{V} / \mathrm{U}^{2}\right)\right. \mathrm{R}(\mathrm{A}+\mathrm{UR}-\mathrm{T}) \\
&\left.-\mathrm{V} / \mathrm{U}^{3}(\mathrm{~A}+\mathrm{UR}-\mathrm{T})^{2}\right]=0
\end{aligned}
$$

$\mathrm{T}, \mathrm{V}, \mathrm{R}$, and $\mathrm{V}$ values were calculated for each kind of larvae for each of the 11 experiments. A 7094 digital computer was programmed to select all T, V, R, and IV values for one kind of larva and to determine by a trialand-error method the $U$ value that best satisficd equation III.

An estimate of the goodness of fit of $\mathrm{T}$ and $\mathrm{R}$ values to the linear regression line $U$ was determined by this equation:

$$
\mathrm{S}=\left(\mathrm{W}+\mathrm{V} / \mathrm{U}^{2}\right)(\mathrm{A}+\mathrm{UR}-\mathrm{T})^{2}
$$

Only two experiments were conducted using warmouth eggs, and the mean incubation temperatures of these two experiments differed by only $0.3^{\circ}$ C. Consequently, the alpha thresholds and the numbers of developmental units necessary for 5()-pereent hatching of warmouth and the three kinds of hybrid zygotes produced from warmouth eggs are not reliable. The alpha thresholds, numbers of developmental units necessary for 50-percent hateling, and $S$ values for the other 12 kinds of $z y$ gotes are presented in Table 10.

The $f$ test comparisons revealed that 
Table 10.-Alpha temperature thresholds of development and numbers of developmental units (degree-hours of effective temperature) necessary for 50-percent hatching of red-ear sunfish, bluegill, green sunfish, and nine different kinds of hybrid sunfish zygotes. (See Tables 5-8 for mean incubation temperatures.)

\begin{tabular}{|c|c|c|c|c|c|c|}
\hline \multirow{2}{*}{$\begin{array}{c}\begin{array}{c}\text { Parent } \\
\text { Spccicso }\end{array} \\
\delta \times \%\end{array}$} & \multirow{2}{*}{$\begin{array}{l}\text { Number of } \\
\text { Eggs that } \\
\text { Hatched }\end{array}$} & \multicolumn{2}{|c|}{ Alpha Threshold } & \multicolumn{2}{|c|}{$\begin{array}{c}U \text { Values } \\
\text { (Degree-hours of } \\
\text { Effective Temperature) }\end{array}$} & \multirow{2}{*}{$\stackrel{S}{\text { Valuest }}$} \\
\hline & & $\begin{array}{c}\text { Degrees } \\
\text { Centigrade }\end{array}$ & $\begin{array}{c}\text { Degrees } \\
\text { Fahrenheit }\end{array}$ & $\begin{array}{c}\text { Centigrade } \\
\text { Scale }\end{array}$ & $\begin{array}{l}\text { Fahrenheit } \\
\text { Scale }\end{array}$ & \\
\hline$R \times R$ & 202 & 18.3 & 64.9 & 280 & 504 & 7.76 \\
\hline$B \times R$ & 211 & 18.3 & 64.9 & 290 & 522 & 0.16 \\
\hline $\mathrm{G} \times \mathrm{R}$ & 255 & 17.8 & 64.0 & 302 & 543 & 1.05 \\
\hline$W \times \mathbf{R}$ & 175 & 18.1 & 64.5 & 284 & 511 & 6.32 \\
\hline$B \times B$ & 592 & 18.3 & 64.9 & 287 & 516 & 1.52 \\
\hline $\mathrm{R} \times \mathrm{B}$ & 638 & 17.9 & 64.2 & 299 & 538 & 20.73 \\
\hline$G \times B$ & 559 & 18.5 & 65.3 & 279 & 503 & 6.58 \\
\hline $\mathrm{W} \times \mathrm{B}$ & 429 & 18.1 & 64.6 & 249 & 448 & 7.33 \\
\hline$G \times G$ & 498 & 18.5 & 65.3 & 266 & 478 & 0.54 \\
\hline$R \times G$ & 481 & 18.3 & 64.9 & 267 & 481 & 24.21 \\
\hline$B \times G$ & 432 & 18.6 & 65.5 & 258 & 464 & 7.80 \\
\hline IV $\times G$ & 513 & 18.6 & 65.4 & 258 & 464 & 5.08 \\
\hline
\end{tabular}

${ }^{a} \mathbf{R}=$ red-ear sunfish, $B=$ bluegill, $\mathbf{G}=$ green sunfish, $W=$ warmouth.

$\dagger \mathrm{S}$ values can be considered equivalent $t, \mathrm{Chi}$ square values, and $\mathrm{S}$ values larger than 3.83 indicate that the deviations of $T$ and $R$ values from their linear regression line $U$ are significantly' greater 60.05 probability level) than deviations due to chance.

the alpha thresholds of development of the 12 kinds of fishes were not significantly different from one another. The alpha thresholds ranged from $17.8^{\circ}$ to $18.6^{\circ} \mathrm{C}$. $\left(64.0^{\circ}-65.5^{\circ} \mathrm{F}\right.$. $)$ and the mean alpha threshold for all 12 kinds of fishes was $18.3^{\circ}$ C. $\left(64.9^{\circ} \mathrm{F}\right.$.). Approximately 280 developmental units centigrade scale or 500 units Fahreuheit seale were necessary for 50 -percent hatching.

The $S$ values for bluegills, green sunfish, BR $F_{1}$ hybrids, and GR $F_{1}$ hybrids indicate that the magnitude of the deviations of the weighted $\mathrm{T}$ and $\mathrm{R}$ values from their respective linear regression lines, $\mathrm{U}$, are within the range that can be attributed to chance. $S$ vahues for the other eight kinds of fishes indicate that the deviations of their $T$ and $R$ values from $U$ are greater than can be attributed to chanee.

Why these greater-than-expected deviations occurred is not known; however, if the relation of incubation temperature to the reciprocal of hatching time is linear for median effective temperatures (Allee et al. 1949:109) and if the values of the statistical weights $V$ and $W$ were correctly estimated, differences in the sizes of eggs from different females or environmental differences such as carbon clioxide and oxygen tensions could be responsible for such deviations.

Differences in the sizes of eggs undoubtedly result in differences in time of hatching. Newly hatehed larvac from large eggs are larger than those from small eggs, and Larimore (1957: 45-46) noted that warmouth larvae emerging from eggs early during the hatching period were smaller ( 2.30 $2.60 \mathrm{~mm}$ in total length) than those emerging later $(2.65-2.85 \mathrm{~mm}$ in total length). Consequently, if eggs were incubated under similar conditions, small eggs would hatch in less time than large eggs.

Alclerdice, Wickett, \& Brett (195S: 229) found that Pacifie salmon eggs exposed to low clissolved oxygen levels just prior to hatching hatched prematurely. Low dissolved oxygen levels may affeet sumfish eggs in the same manner. 
In the 11 experiments reported here, a high positive correlation between high mortality prior to hatching and premature hatching should be apparent if envirommental clissolved oxygen levels became critical enough to affect the time of batching. An inspection of the clata revealed no such correlation; consequently, in these experiments differences in the sizes of eggs from different females appear to be a more likely source of experimental error than low levels of environmental dissolved oxygen.

\section{Isolation Experiments}

Thirty-two isolation experiments were conducted from 19.57 through 1963. Sixteen of these experiments, all of which involved intrageneric Lepomis matings, were reported by Childers \& Bennett (1961:6).

Methons and Materials.-Majes of one species and females of a different species were isolated in small earthen ponds (0.02-0.90 acres). Each of the 12 possible hybrid-producing combinations was tested in one or more ponds. Shortly before the ponds were stocked with the parent species, each pond was drained or treated with rotenone to eliminate any fish which might be present. Parent species were stocked during late May or early June and the ponds were checked at approximately monthly intervals throughout the summer.

The following August or September each pond was clrained, seined, or treated with rotenone, and small fish (if present) were identified. Three of the 32 ponds had become contaminated with other fish, and two ponds dried up during the late summer. No hybrids were found in these five ponds. Results of the other 27 experiments are reported in Table 11.

Results ANd Discussion.- $R \times$, $\mathrm{G} \times \mathrm{B}$, and $\mathrm{W} \times \mathrm{G}$ pairings successfully hybridized each time they were tested. $\mathrm{R} \times \mathrm{G}$ and $\mathrm{G} \times \mathrm{B}$ were each tested in two ponds and $W \times G$ was tested in one.
The $B$ x $G$ cross, not includefl in Table 1I, was attempted in two ponds. Both ponds became contaminated with male green sunfish, and large numbers of green sunfish young were protuced in both ponds. Conserguently, both experiments gave no test of hybridization between bluegill males and green sumfish females.

The $\mathrm{R} \times \mathrm{B}$ cross was attempted in four ponds. No hybrids were produced in three ponds although the ponds remained full and were uncontaminated by other fishes. Eleven small fish were found when the fourth pond was drained, and these fish were believed to have heen $\mathrm{RB} \mathrm{F}_{1}$ hybrids although they were not positively identified as such (Childers \& Bennett 1961:6). The water in this pond contained a high and constant claty turbidity that reduced the transparency of the water and caused the parent fish to be extremely pale in body color. The normally scarlet portions of the opercle tabs of the red-ear males appeared as a faint rose color. The $R \times B$ cross has been attempted three times in lndiana without obtaining offspring (Krumhol\% 1950:113).

The $B \times R$ cross was set $u p$ in four ponds. Three of these (not included in Table 11) were improper because of contamination by bluegill females in onc and complete loss of water in the other two during the late summer. The fourth test appeared to have been valid but no hybrids were produced.

Smitherman \& Hester (1962:335, 3.37) attempted $R \times B$ and $B \times R$ erosses by stocking single pairs in plastic pools 9 feet in diameter and 2.5 feet deep. Each cross was attempted in two pools, and hybridization failed to occur in all four trials. In contrast to these results, the $B \times R$ cross has heen prochuctive of hyhrids six times in Indiana (Krumholz 1950:113).

Adults for the $\mathrm{R} \times \mathrm{IT}^{7}$ cross were stocked in two ponds. One pond became contaminated with male and female green sunfish, and when the 
Table 11.-Results of isolation experiments. Adult males of one species and females of another were isolated in each pond in May or June, and ponds were censused in August or September, 1957-1963.

\begin{tabular}{|c|c|c|c|c|}
\hline \multirow{2}{*}{$\frac{P_{1} \text { Cross }^{\circ}}{\delta \times \circ}$} & \multirow{2}{*}{$\begin{array}{c}\text { Pond Surface Area } \\
\text { in Acres }\end{array}$} & \multicolumn{2}{|c|}{$\begin{array}{c}\text { Number } \\
\text { of Aduits Stocked }\end{array}$} & \multirow{2}{*}{ Results } \\
\hline & & $\hat{o}$ & 오 & \\
\hline $\mathrm{R} \times \mathrm{B}$ & 0.02 & 4 & 6 & 11 young found \\
\hline $\mathrm{R} \times \mathrm{B}$ & $0.10_{+}^{+}$ & 15 & 10 & No hybrids \\
\hline $\mathrm{R} \times \mathrm{B}$ & $0.10_{+}^{+}$ & 13 & 15 & No hybrids \\
\hline $\mathrm{R} \times \mathrm{B}$ & $0.80+$ & 16 & 11 & No hybricls \\
\hline$B \times R$ & $0.25+$ & 8 & 22 & No hylsrids \\
\hline$R \times G$ & 0.02 & 4 & 7 & Hybrids abundant \\
\hline $\mathrm{R} \times \mathrm{G}$ & 0.04 & 8 & 3 & Hybrids abundant \\
\hline $\mathrm{G} \times \mathrm{R}$ & 0.10 & 2 & 8 & No hybrids \\
\hline$C \times R$ & 0.02 & 4 & 6 & No hybricls \\
\hline $\mathrm{G} \times \mathrm{R}$ & $0.10+$ & 8 & 11 & No hybrids \\
\hline $\mathrm{G} \times \mathrm{B}$ & 0.02 & 4 & 6 & Hybrids abundant \\
\hline$G \times B$ & 0.90 & 30 & 35 & Hybrids abundant \\
\hline$W \times R$ & 0.20 & 12 & 4 & No hybrids \\
\hline$W \times R$ & 0.20 & 6 & 19 & No hyloricls \\
\hline $\mathrm{R} \times \mathrm{WV}$ & $0.75+$ & 13 & 6 & No hybrids \\
\hline$R \times V$ & $0.25+$ & 12 & 28 & Contaminated \\
\hline W $\times \mathrm{B}$ & 0.02 & 4 & 5 & No hybrids \\
\hline$W \times B$ & 0.02 & 4 & 5 & No hybrids \\
\hline$W \times B$ & 0.02 & 4 & 5 & No hybrids \\
\hline$W \times B$ & 0.02 & 4 & 5 & No hybrids \\
\hline$B \times W$ & 0.02 & 6 & 5 & No hybrids \\
\hline$B \times W$ & 0.02 & 5 & 3 & No hybrids \\
\hline$B \times W$ & 0.02 & 5 & 3 & No hybrids \\
\hline$B \times \mathrm{IV}$ & 0.02 & 3 & 2 & No bybrids \\
\hline$W \times G$ & 0.02 & 4 & 6 & Hybrids abundant \\
\hline$G \times \mathrm{WV}$ & $0.10 \neq$ & 8 & 8 & No bybrids \\
\hline$G \times I V$ & 0.02 & 4 & 6 & No hybrids \\
\hline
\end{tabular}

${ }^{\circ} \mathrm{R}=$ red-ear sunfish, $\mathrm{B}=$ bluegill, $\mathrm{G}=$ green sunfish, $\mathrm{W}=$ warmouth.

†The 11 young sunfish were believed to be hybids but were not positively identified as sucl.

$\ddagger$ Size of pond estiunted. were found.

pond was seined during September, it contained large numbers of young-ofthe-year green sumfish and RG or GR $F_{1}$ hybrids. No RW hybrids were found in either pond.

Although the $\mathrm{R} \times \mathrm{W}$ cross was unsuccessful in these experiments, I found a large natural population of RIV hybrids in a 2-acre farm pond near Fairmount, Ill. This pond was stocked in 1952 with warmouths, red-ear sunfish, and smallmouth bass. No liybrids were found during 1953 or 1954. During March, 1955, all three species in this pond suffered extensive mortality be- cause of critical dissolved oxygen conditions. A large population of RIV hybrids was produced following this spring mortality. Since stripping experiments indieated the $W \times R$ cross resulted in nonviable hylbrids, the natural hybrid population was apparently produced by male red-ears and female warmouths.

The G $\times$ R (three tests), IV $\times \mathrm{R}$ (two tests), $W \times B$ (four tests), $B \times W$ (four tests), and G $\times$ W (two tests) all failed to produce hybrid populations although the parent speeies had good opportunities to hybridize in each test. 
In each of the 32 isolation experiments males constructed nests and remained in spawning condition for extended perjods throughout the summer. The failure of certain $\mathrm{P}_{1}$ crosses to hybridize was believed to result from incompatibilities in the reproductive behavior patterns of the various species and not because males and females failed to be in spawning condition at the same time.

Fish hybridization might result from sperm driftage or interspecific matings. Sperm driftage is an important cause of hybridization among certain species of fishes, particularly minnows and darters, which live in flowing water habitats and simultaneously spawn in close proximity to one another (Hubbs 195̃5: 10, 16). Sperm driftage may also account for some bybridization between pond- or lake-dwelling centrarchids; however, since average functional life spans of sunfish spermatozoans are so brief (Tables 2-4) and since there is such good synchronization in the release of sperm and eggs by a spawning pair, most hybrid sumfish are probably the result of interspecific pair formation.

The four experimental species are sexually dimorphic, closely allied, sympatric species. Signals that are in some way involved in reproductive isolation of such species are likely to be highly divergent (Marler 1957:35) and may involve specific differences in shape, color, special movements, sounds, scents, etc. (Tinbergen 1951:56). The precise signals which are operative in conspecific pair formation of the four experimental species are not known; however, specific differences in color of opercle tabs, eyes, cheeks, and pelvic fins of nest-guarding males (Table 1) may be important in controlling the behavior of ripe females. When a female ready to spawn approaches a nestguarding male, she usually stops some distance from the nest and the male exhibits a courtship display (Miller 1963:118). Species recognition appar- ently occurs during this short time, and the female flees or remains in the vicinity of the nest and accepts the advances of the male.

Since in one isolation experiment there was an indication that the scarlet portions of the opercular tabs of male red-ear sunfish might possibly prevent hybridization between male red-ears and female bluegills, an experiment was conducted during 1964 to test this hypothesis. Two small earthen ponds (25 feet wide, 45 feet long, with a maximum depth of 4 feet) were each stocked during July with three ripe adult male red-ear sunfish and three adult female bluegills. The opercular tabs were clipped from all males stocked in one pond, and the tabs were left intact on the males stocked in the other pond.

The ponds were drained during early October, and several thousand small (0.5-1.0 inch in total length) hybrid fry were collected from the pond containing red-ear males whose opercular tabs had been removed. No small fish were found in the control pond. An examination of the clipped males revealed that the blue portion of the opercular tabs had regenerated to almost normal size but the scarlet portions had not regenerated. One tab on each of these males had a small, narrow, yellowish-orange margin.

One such test cannot, of course, be considered conclusive proof that specific differences in the color of the opercular tabs of male red-ears are highly functional in preventing their hybridization with female bluegills; however, additional investigation of the importance of color as a reproductive isolating mechanism in the sunfishes might prove rewarding.

According to Iubbs (1957:17), fish hybridization is controlled to a large extent by environmental factors. Sunfish hybrids appear to be more common in ponds which are cloked with aquatic vegetation or have high turbidities than in clear-water ponds which have ex- 
tensive spawning areas free from vegetation. In weed-choked ponds or ponds with high turbidities the range of visibility must be short, and under these conclitions ripe females might occasionally spawn with males withont observing preliminary courtship displays believed to be important in conspecific pair formation.

\section{HYBRIDS REARED IN PONDS}

Large numbers of each of the 10 viable $F_{1}$ hybrid types were stocked in one or more ponds. Most of these hybricls were produced in the laboratory by combining sex products stripped from ripe adults of the four parent species. However, a few were produced by isolating males of one species and females of another species in ponds which contained no other fish. The laboratory hybrids were stocked on the clay they became free-swimming; the pond-produced liybrids were seined and stocked in other ponds when they had attained a length of about 1 inch.

The $\mathbf{F}_{1}$ hybrids were reared to maturity in their respective ponds and the sex ratio, fecundity, and degree of heterosis of each $F_{1}$ hybrid population were studied.

\section{Sex Ratios}

After the $F_{1}$ hybrids had grown to sexual maturity, fish were collected from each population and sexed, mostly by dissection. However, some were sexed by stripping eggs or milt from ripe individuals, and fewer still were sexed by reference to color, size of abdomen, and comparative size and shape of anus and urogenital openings.

The sex of a mature sunfisl is not difficult to determine by observation during the spawning period. Male sunfish are usually more vividly colored than females. The ahdominal region of females becomes greatly distended with eggs shortly before spawning occurs. The diameter of the urogenital opening in male sunfish is usually less than one- half the diameter of the anus, but in females it is equal to or larger than the diameter of the anus. In male sunfish the urogenital opening forms a cupshaped depression and in females it forms a small papilla.

If there was any doubt as to the sex of a particular indivichal, that individual was dissected. The accuracy of determining sex by observation was checked several times by dissecting all fish in a particular sample in which the fish had been previously sexed by observation. No errors were revealed.

The sex ratios, expressed as the percentage of males, for each of the 10 different kinds of viable $\mathrm{F}_{1}$ hybrids produced from the four experimental species are reported in Table 12. Sex ratios determined for population of the six intrageneric Lepomis hybrids reported by Childers \& Bennett (1961:7) are inclucled in Table 12.

Table 12.- Sex ratios of $F_{1}$ hybrid sunfishes expressed as the percentage of males in individual populations.

\begin{tabular}{|c|c|c|c|}
\hline $\begin{array}{c}F_{1} \\
\text { Ifybrid } \\
\text { Populations }\end{array}$ & $\begin{array}{l}\text { Where } \\
\text { Produced }\end{array}$ & $\begin{array}{l}\text { Number } \\
\text { Sexed }\end{array}$ & $\begin{array}{l}\text { Percent } \\
\text { Male }\end{array}$ \\
\hline $\mathrm{RB}$ & $\mathrm{L}$ & 178 & 100 \\
\hline $\mathrm{RB}$ & $\mathrm{L}$ & 197 & $100+$ \\
\hline \multirow[t]{2}{*}{$\mathrm{RB}$} & \multirow[t]{2}{*}{ L } & 95 & 87 \\
\hline & & 470 & 97 \\
\hline BR & L & 110 & 97 \\
\hline $\mathrm{RG}$ & L & 457 & 69 \\
\hline GR & L & 252 & 48 \\
\hline$B G$ & L & 142 & 97 \\
\hline GB & $\mathrm{P}$ & 44 & 70 \\
\hline \multirow[t]{2}{*}{ GB } & \multirow[t]{2}{*}{$\mathrm{P}$} & 22 & 64 \\
\hline & & 66 & 68 \\
\hline RIV & L. & 174 & 55 \\
\hline BIV & $\mathrm{L}$ & 101 & 66 \\
\hline \multirow[t]{2}{*}{$\mathrm{BW}$} & \multirow[t]{2}{*}{ L. } & 302 & 70 \\
\hline & & $\overline{403}$ & 69 \\
\hline$G I^{\top}$ & $\mathrm{L}$ & 147 & 16 \\
\hline IVG & $\mathrm{P}$ & 104 & 84 \\
\hline
\end{tabular}

${ }^{\circ} \mathrm{R}=$ red-ear sunfish, $\mathrm{B}=$ bluegill, $\mathrm{G}=$ green sunfish, W $=$ Warmouth. In names of hybrids the male parent species is given first.

$\neq \mathrm{L}=$ laboratory-prodnced hybrids and $\mathbf{P}=$ pondproduced hyhrids.

$\neq$ One F. hyhrid was collected from this pond; so at least one female wis in this population. 
, 

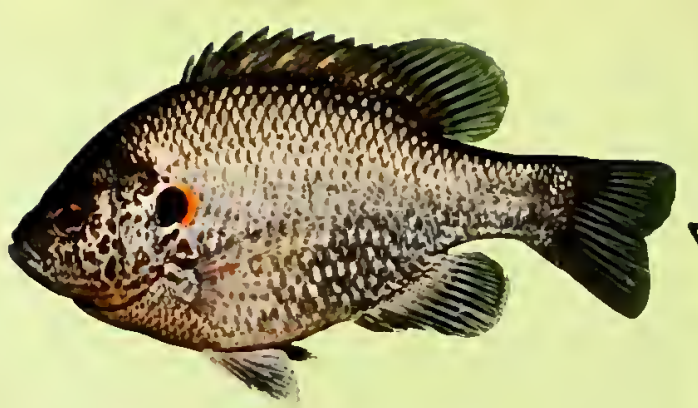

RED-EAR SUNFISH

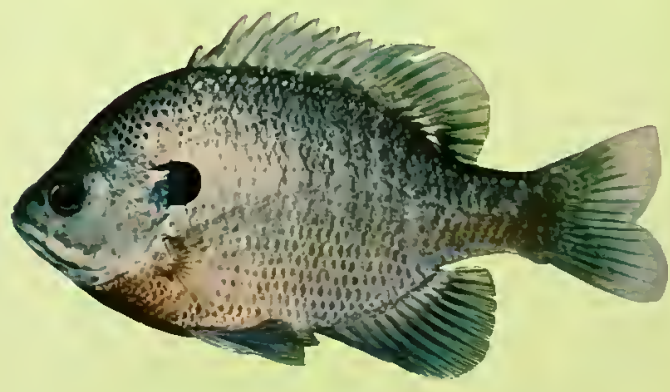

BLUEGILL

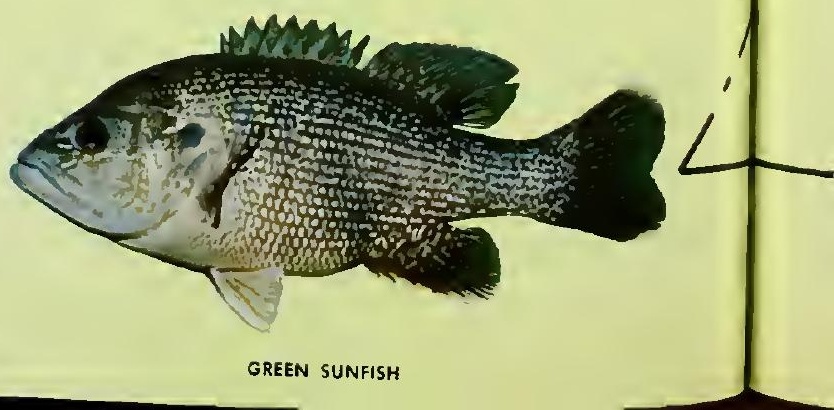




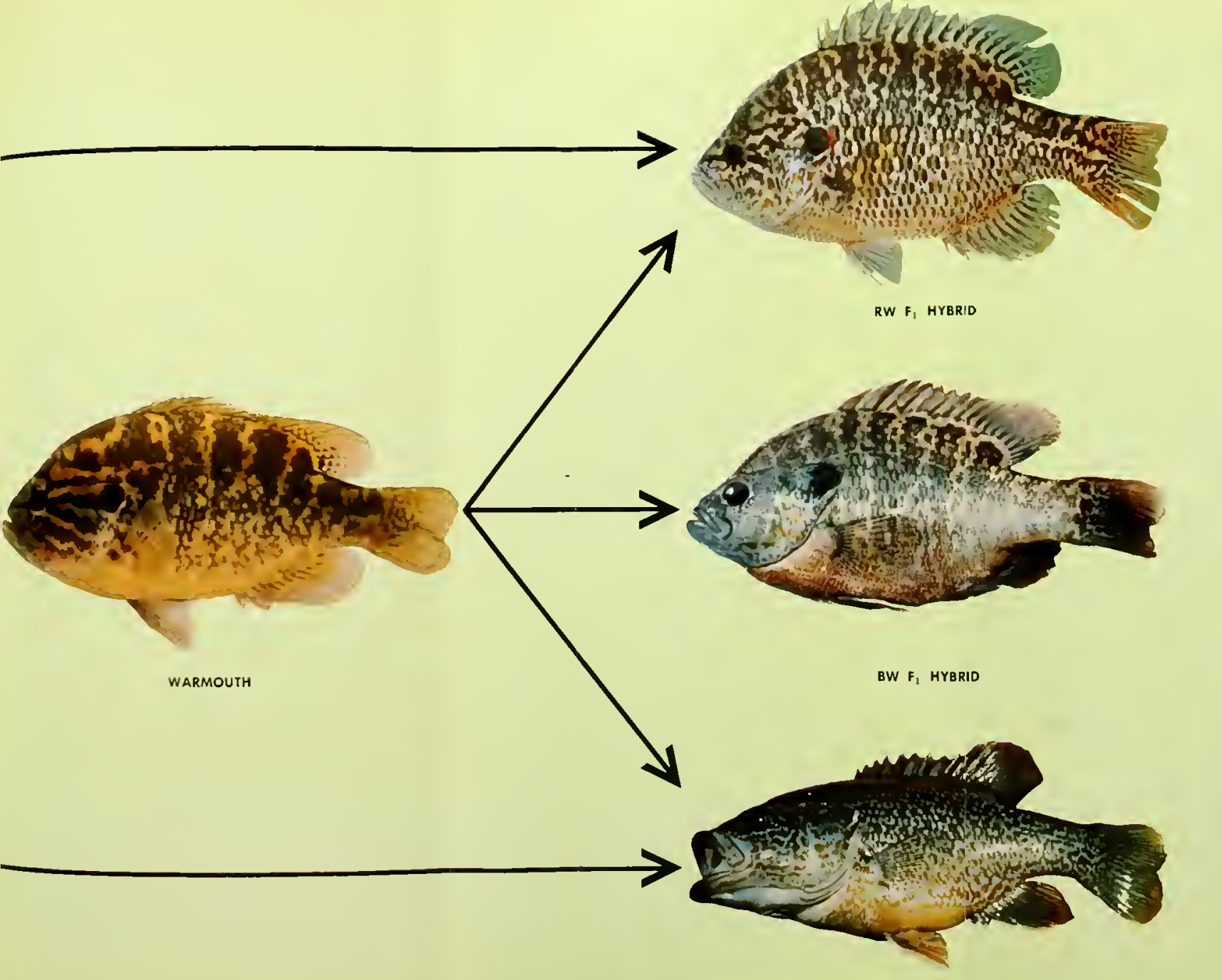

WG $F_{1}$ HYBRID

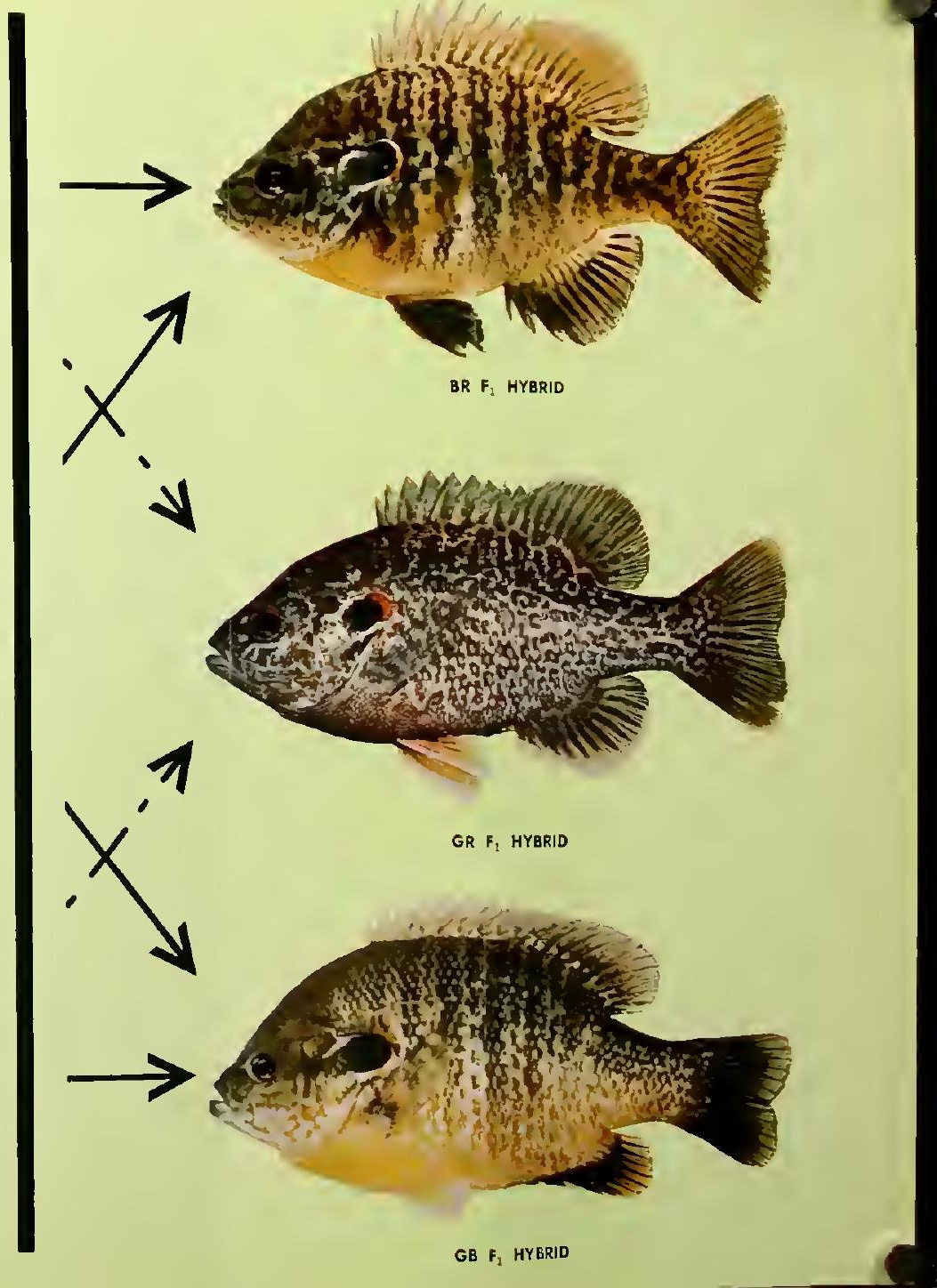



Of the 10 kinds of viable $F_{1}$ hybrids, seven were predominately males ( $R B$, BR, and BG were 97 percent males; IVG were 84 percent males; and $R G$, $\mathrm{GB}$, and $\mathrm{BW}$ were approximately 70 percent males), two were approximately 50 percent males ( $\mathrm{GR}$ and $R(V)$, and one was predominately female (GIV was 16 pereent males). Ricker (1945:93-94) determined the sex of $428 \mathrm{BR} \mathrm{F}_{1}$ lyybrids in Indiana and found them to be 97.7 percent males.

Sex determination in sunfishes is very poorly understood. Bluegills, green sunfish, and their $F_{1}$ hybrids apparently have 24 pairs of chromosomes, and the sex chromosomes are indistinguishable from the autosomes (Bright 1937:36). Bright (1937:26) also reported that the chromosomes are so similar in shape and size that he was unable to detect specifie differences. Roberts (1964:402) found that red-ear, bluegill, and warmouth sunfishes each have 24 pairs of chromosomes; green sunfish from Wake County, N.C., had 24 pairs; but green sunfish from Leetown, W.Va., had only 23 pairs.

The unbalanced phenotypic tertiary ${ }^{1}$ sex ratios of the $F_{1}$ hybrid sumfish could result from unbalance primary genetic sex ratios, specific differences in the strength of sex-determining factors, an overricling of the genetic sex by envirommental factors, or clifferential mortality of the sexes.

Since the WVG $F_{1}$ hybrids were 84 percent males and the reeiprocal cross hybrids were 16 percent males, it is possible that the strength of sexdetcrmining factors of warmoutls are 5.25 times more powerful than those of green sunfish. Specific differences in the strength of sex-determining factors callnot alone explain the sex ratios of the remaining eight kinds of viable bybrids,

\footnotetext{
IIn this paper the terms primary, secondary, and tertiasy sex ratios refer to sex ratios at the finc of fertilization, time of hatching, and time of sexual maturity, respectively. Conetic sex refers to the type of sex chromosomes an inclividual receives from its parents, and phenotypic sex refers to whether its gonads are testes or ovaries.
}

since none of these were predominantly females.

$\mathrm{RB}$ and $\mathrm{BG} \mathrm{F}_{1}$ hybrids were both 97 percent males. If differential mortality were the cause of these unbalanced sex ratios, much of the mortality would have had to occur after the swim-up fry stage, since in the stripping experiments total mortality between fertilization and the swim-up fry stages was only 14 percent for the RB and 27 percent for the BG F $F_{1}$ lybrids.

It is not known which sex is the heterozygous condition for the sex ehromosomes of the four experimental species; however, Haldanc (1922:108) formulated a rule which furnishes a clue.

When in the $F_{1}$ offspring of a cross between two animal species or races, one sex is absent, rare, or sterile, that sex is always the heterozygous sex.

Using Haldane's rule, Krumholz (1950:114), in a study eonceming BR $F_{1}$ hybrids, pointed out that the males of both bluegills and red-ear sumfish are probably homozygous for sex and the females heterozygous. The applieation of Haldane's rule to all possible $F_{1}$ liybrids produced from red-ear sunfish, bluegills, and green sunfish indicates that the fomale is the heterozygous sex in these three species. Hybridization of male warmouths with females of the three Lepomis species resulted in partial or complete lethals, suggesting that in the wamouth the male is the heterogametic sex.

\section{Fecundities}

The reproductive success of each of the 10 kinds of viable $F_{1}$ hybrids was investigated in one or more ponds. The occurrence and abundance of $F_{2}$ hybrids were determined by scining, trapping, shocking, poisoning, or draining the ponds after the $F_{\text {, }}$ liybrids were 1 or more years of age. Eighteen separate populations were studied. The results of these studies are presented in Table 13.

Of the 10 kinds of viable $F_{1}$ lyylurids, 
Table 13. - The occurrence and estimated abundance of $F_{2}$ hybrids in ponds stocked with $F_{1}$ hybrids.

\begin{tabular}{llll}
\hline $\begin{array}{c}F_{1} \\
\text { Hybrid }\end{array}$ & Pond & \multicolumn{1}{c}{$\begin{array}{c}\text { Abundance of } \\
F_{2} \text { Hybrids }\end{array}$} \\
\hline RB & 1 & None found & \multicolumn{1}{c}{$\begin{array}{c}\text { Other Species } \\
\text { Present }\end{array}$} \\
RB & 2 & None found & None \\
RB & 3 & One individual found & None \\
BR & 4 & None found & Hybrid crappies \\
RG & 5 & Abundant & None \\
RG & 6 & Abundant & None \\
RG & 7 & Scarce & None \\
GR & 8 & Scarce to abundant $\dagger$ & Largemouth bass \\
BG & 9 & None found & None \\
GB & 10 & Abundant & None \\
GB & 11 & Scarce & None \\
RW & 18 & Abundant & Largemouth bass \\
BWV & 15 & None found & None \\
BWV & 16 & Alundant & Largemouth bass \\
BWV & 17 & Scarce & Hybrid crappies \\
& & & Largemouth bass, bluegills, \\
lake chubsuckers, warmouths, \\
GWV
\end{tabular}

${ }^{\circ} \mathrm{R}=$ red-ear sunfish, $\mathrm{B}=$ bluegill, $\mathrm{G}=$ green suufisb, $\mathbf{W}=$ warmoutb. In names of bybrids the male parent species is given first.

tWhen the $F_{1}$ bybrid population was dense, only a few $F_{2}$ hybrids were found. The number of $F_{1}$ hybrids was drastically reduced and the few remaining $F_{1}$ bybrids produced a large number of $F_{2}$ hybrids the following year.

$\ddagger$ These fish were believed to be $F_{2}$ hybrids; however, they could have been produced by the $F_{1}$ hybrids backerossing to either of their parent species.

$\mathrm{RB}, \mathrm{BR}$, and $\mathrm{BG}$ failed to produce abundant $F_{2}$ generations when in ponds which contained no other species of fishes. In contrast to these results, BR $\mathbf{F}_{1}$ hybrids produced abundant $F_{2}$ generations in two ponds in Indiana (Ricker 1948:94). Six of the other seven kinds of $F_{1}$ hybrids produced abundant $\mathrm{F}_{2}$ hybrids when in ponds which contained no other species of fishes, and the seventh, stocked in a pond with $\mathrm{F}_{1}$ hybrid crappies, also produced a large $F_{2}$ generation.

Three of the seven kinds of $F_{1}$ hybrids which produced large $F_{2}$ populations when stocked in ponds containing either no other fishes or hybricl crappies were also stocked in ponds with largemouth bass. RG $F_{1}$ hybrids and GB $F_{1}$ hybrids, when stocked with largemouth bass, produced only a few $F_{2}$ lybrids. No $F_{2}$ hybrids were found in the pond stocked with BWV $F_{1}$ hybrids and largemouth bass. Only a few $B W V F_{2}$ hybrids were found when an 18-acre lake containing $\mathrm{BW} \mathrm{F}_{1}$ hybrids; largemouth bass; warmouths; bluegills; channel catfish, Ictalurus punctatus (Rafinesque); and lake chubsuckers, Erimyzon sucetta (Lacépède), was drained.

The results of these experiments, although not conclusive because of the small number of trials, do indicate that $R G$, GB, and BIV $F_{1}$ lyybrids which are capable of producing large $\mathbf{F}_{2}$ populations in ponds containing either no other specics or hybrid crappies are unable to do so in ponds containing largemouth bass. It is not known whether scarcities of $F_{2}$ hybrids in ponds containing largemouth bass are the result of low fecundity of $F_{1}$ hybrids or a high vulnerability of $\vec{F}_{2}$ 
hybrids to bass predation. Both possible causes may be important. Hale (1956: 105) found that green sunfish with forebrain lesions exhibited a marked reduetion in their ability to learn to negotiate a maze. It would be interesting to know if the forebrains of the $\mathrm{F}_{2}$ hybrids are structurally or functionally different from those of $F_{1}$ lybricls or their parent species.

IVG $F_{2}$ hybrids, stocked in a pond which contained no other fishes, produced a large $F_{3}$ generation. GIV $F_{2}$ hybrids, which were stocked in a pond containing no other fishes, also produced a large $F_{3}$ population.

Backcrosses, outcrosses, a four-species cross, and a three-species cross involving $F_{1}$ lyybrids are listed in Table 14 . The $B W \times \mathrm{B}$ backcross was made by stocking adult male BW $F_{1}$ hybrids and adult female bluegills in a pond which contained no other fishes. The other 12 crosses listed in Table 14 were made by stripping gametes from ripe adults and rearing the young to the free-swimming fry stage in the laboratory.

R $x$ RIV, IV $x$ RW, B $x$ RIV, G $x$ RW, $\mathrm{R} \times \mathrm{GB}$, and $\mathrm{RB} \times \mathrm{W}$ young were killed after they developed into free-swimming fry because of the lack of ponds in which they could be stocked. All six kinds of fry appeared to be normal and probably would have developed into

Table 14.-Successful backcrosses, outcrosses, four-way cross, and another cross involving $F_{1}$ hybrid sunfishes."

\begin{tabular}{|c|c|c|c|}
\hline Backcrosses & Outcrosses & $\begin{array}{c}\text { Four-Species } \\
\text { Cross } \\
\end{array}$ & $\begin{array}{c}\text { Three-Species } \\
\text { Cross }\end{array}$ \\
\hline$f \times q$ & $\delta \times$ ? & $8 \times 9$ & J $\times$ क \\
\hline $\begin{array}{l}R \times R I V \\
C \times C W \\
W \times R W \\
B W \times B\end{array}$ & $\begin{array}{lll}R & \times & G B \\
R & \times & B W \\
R & \times & G W \\
B & \times & R G \\
B & \times & R W \\
G & \times & R W \\
R B & \times W\end{array}$ & $\mathrm{RB} \times \mathrm{CH}$ & $B W^{\prime} \times \mathrm{CW}^{\prime}$ \\
\hline
\end{tabular}

${ }^{\circ} \mathrm{R}=$ red-ear sunfish, $\mathrm{B}=$ bluegill, $\mathrm{C}=$ green sunfish, ${ }^{\circ}=$ red-ear sunf adults. Free-swimming fry of the remaining six crosses in the laboratory were stocked in ponds and did develop into adult fishes. $\mathrm{BW} \times \mathrm{B}, \mathrm{G} \times \mathrm{GW}$, and $B \times$ RG populations produced large numbers of young.

Hubbs \& Hubbs (1933:631-636) reported that in Michigan $F_{1}$ hybrids of bluegills, green sunfisl, longear sunfish, pumpkinseeds, and orangespotted sunfish were unable to reproduce because males were sterile and ova stripped from the few adult females used in the experiments appeared distinctly abnormal. This study, often eited in the literature, has resulted in a rather widespread belief that all male hybrid sunfish are sterile. Results of my experiments eonclusively establish that a number of different kinds of hybrid sunfishes produced in lllinois are not sterile, are fully capable of producing abundant $F_{2}$ and $F_{3}$ generations, and can be successfully backcrossed to parent species and even outcrossed to nonparental species.

\section{Hybrid Vigor}

Heterosis has been defined (Manwell, Baker, \& Childers 1963:103) as

that condition where, with respect to onc or more particular characteristics, the values for most, if not all, of the individual hybrids fall significantly outside the range formed from the means for both parent populations. In cases of positive heterosis-hybrid vigor-the hybrid shows a faster growth rate than either of the parents, or it possesses some other characteristic, often an economically significant one, at a "better" level than the parents do.

Rate of Growtri.-The growth of the different kinds of hylorids stocked in ponds was recorded for each of the populations mentioned in Tables 12 and 13 . Since various numbers $(200$ 10,000 per surfaee aere) of lyblorids were stocked and since the ponds differed in size, deptl, shape of basin, and fertility, no valid comparisons can be made between the growth rates of the hybrids or between those of the lyybrids and their parent speeies. In general the rates of growth of these hybrids were inversely proportional to 
their population densities. The most rapid growth during the lst year of life occurred in a 1-acre pond stocked on May 24, 1957, with approximately 1,000 free-swimming, laboratory-produeed, 1-day-old RIV $F_{1}$ hybrid fry. Approximately 41/2 months later, Oetober 8,66 hybrids from this population averaged $145 \mathrm{~mm}$ ( 5.7 inches) in total length and 69 grams ( 0.15 pound).

The slowest growth occurred in a 0.1-acre pond stoeked on May 27, 1957, with approximately $1,000(10,000$ per surface acre) 1-day-old, free-swimming, laboratory-produced GR $F_{1}$ hybrid fry. On August 30, 106 hybrids from this population averaged only $94 \mathrm{~mm}$ (3.7 inehes) total length. The fish in this sample were not weighed; however, based on the weights of fish of similar lengths from later samples, the calculated average weight of fish from the August 30th eollection was about 15 grams (0.03 pound).

The largest hybrid captured to date (May, 1965) was a 6-year-old GB $F_{1}$ hybrid whose total length was $310 \mathrm{~mm}$ and weight was 965 grams (Frontispiece).

Hubbs \& Hubbs (1931:291, 296-297) during 1929 and 1930 studied the growth of pumpkinseed, green sunfish, and the naturally produced hybrid of these two speeies in Wiard's pond near Ypsilanti, Mich. Average lengths of both 1-and 2-year-old hybrids in this pond were greater than those of either parent species. The effeet on growth of the relative abundance of the three kinds of fishes in this pond (pumpkinseeds, green sunfish, and their hybrids ) was not considered. Based on the total number of individuals reported, pumpkinseeds were approximately 10 times more abundant than green sunfish and green sunfish twice as abundant as hybrids. Intraspecific eompetition is usually kecner than interspecific competition because individuals of the same species are more nearly equal in their structural, funetional, and be- havioral adaptations (Kendeigh 1961: 183). Consequently, the grcater growth of the hybrid sunfish in Wiard's pond may have been the result of less intraspeeific competition among the hybrids than among the parent speeies and not heeause the hybrids exhibited hybrid vigor.

In an attempt to determine whether certain $F_{1}$ hybrid sunfishes actually grow faster than their parent species, two experiments were conducted in which equal numbers of uniformly sized $F_{1}$ hybrids and parent species were stocked in ponds whieh contained no other fishes (Childers \& Bennett 1961:11-13). In the first experiment, 171 BG $F_{1}$ hybrids and 171 green sunfish averaging about $25 \mathrm{~mm}$ ( 1.0 ineh) and $19 \mathrm{~mm}$ (0.75 ineh), respectively, were stoeked on July 10, 1958, in an 0.8 -acre gravel pit pond. Ten months later (during 4 months of which the waters were warm enough for fish growth) fish were removed from the pond by trapping and rotenone poisoning.

In the second experiment $200 \mathrm{GR} \mathrm{F}_{1}$ hybrids, 200 green sunfish, and 200 redear sunfish averaging $117 \mathrm{~mm}$ (4.6 inches), $107 \mathrm{~mm}$ ( 4.2 inches), and 89 $\mathrm{mm}$ (3.5 inehes), respectively, were stocked in a 1.1-aere farm pond during early August, 1958. Fish were removed from this pond April 20 through May 25. 1959, by hook-and-line fishing, trapping, and rotenone poisoning.

In both experiments the average increase in total length of the hybrids was not significantly different from the increases of the parental species. The population densities of the fishes in both ponds were much lower than would be found in most normal natural populations. In both experiments intraspecific and interspecific competition was undoubtedly quite light; consequently, the question of whether certain $F_{1}$ hybrid sunfishes are superior to their parent speeies in rate of growth camnot be answered until high density 
populations containing cqual numbers of equal-sized hybrids and parent speeies are studied.

Eifectrophoretic Patterns of HenogLobins.-Manwell, Baker, \& Childers (1963:118-119) determined that redear sunfish, bluegills, green sunfish, and warmouths each have a hemoglobin pattern in vertical starch gel electrophoresis that is unique. Almost every one of the $F_{1}$ hybrids of these species yields a hemoglobin pattern that is identical with that obtained by simply mixing hemoglobins of the two parental species; however, from 25 to 40 percent of the hemoglobin from $B W, G W$, and $\mathrm{WWG}^{\mathrm{F}}$, hybrids has electrophoretic properties different from the liemoglobins of the parental speeies. Oxygen equilibria for the hemoglobins from these three hybrids show greater hemeheme interactions than those for hemoglobin from any of their parental species. As a result of this greater lemeheme interaction, hemoglobins from these three hybrids have better blood gas transport properties than those of their parental species, and in this respect each of these three hybrids is helieved to exhibit hybrid vigor.

Vulnerability to Hook-AND-LiNe: Capture-Although no controlled experiment has tested whether $F_{1}$ lyybrid sunfishes are more vulnerable to angling than their parental species, certain $F_{1}$ hybrids are so easily cauglit thit at several locations sport fishermen have almost completely eliminated substantial hybrid sunfish populations in a few days of angling.

For example, on May 30, 1958, the 1llinois Department of Conservation opened the lake at Lincoln Trail State Park near Marshall to public fishing. From May 30 through September 29, fishermen caught and removed approximately 10,800 naturally produced BG or GB $F_{1}$ hybrids of which 50 percent $(5,400)$ were caught during the 1st day of fishing, and 82 percent $(8,600)$ were removed cluring the first
3 days. This hybrid sunfish population was almost completely eliminated during the lst week of fishing.

Ridge Lake, an 18-aere lake in Fox Ridge State Park near Charleston, 1ll., was drained during the fall of 1959 and fish were moved to other waters. In the spring of 1960, the lake was restocked with 4,503 $\mathrm{BWV} \mathrm{F}_{1}$ hybrids, 299 largemouth bass, 41 channel catfish, and 585 lake ehubsuekers. An additional 448 RW $F_{1}$ hybrids were stocked in May, 1961.

A limited number of fishermen was permitted to fish during June, July, and August of 1960, 1961, and 1962. During 1960, fishermen totaled 1,583 manhours of fishing and caught 3,772 of these hybrids, of which 64 were removed and 3,708 returned to the lake. In 1961 fishermen totaled 2,830 manhours of fishing and eaught 4,890 hybrids, of which 194 BW and 6 RIV hybrids were removed. The remaining 4,690 hybrids were returned to the lake. The next season (1962) fishermen were permitted to remove all the hybrids they caught, and during 2,817 man-hours of fishing they removed $1,075 \mathrm{BWV}$ and $134 \mathrm{RWV} \mathrm{F}_{1}$ hybrids. Of these 1,209 hylbrids, 65 percent were caught during the first 5 days of fishing, 81 percent during the first 10 days, and $S 8$ percent during the first 15 days. The lake was drained during March, 1963, and was found to contain S BWV and 64 RiV F, hybrids.

\section{HYBRID SUNFISHES FOR SPORT FISHING}

Overpopulation of sunfish is the single greatest problem encountered in the management of Illinois lakes and ponds containing largemouth hass and one or more of the Lepomis species. The Lepomis species have such high reproductive capaeities and survival capabilities that they commonly become so abundant that they are mable to grow to sizes large enough to be of value to fishermen. Because certain 
kinds of $\mathbf{F}_{\perp}$ hybrid sunfishes appear to be unable to produce sizable $F_{2}$ populations in ponds containing largemouth bass, a number of experiments are now in progress to test the usefulness of luybrids in combination with largenouths. Preliminary results indicate that several types of hybrids in combination with bass furnish fishing superior to that furnished by bass in combination with the hybrids' parent species.

\section{SUMMARY}

1.-Red-ear sunfish, Lepomis microlophus (Günther); bluegill, L. macrochirus Rafinesque; green sunfish, $L$. $c y$ ancllus Rafinesque; and warmouth, Chaenobryttus gulosus (Cuvier) are present in a number of east-central Illinois lakes and ponds and are known to hybriclize occasionally. During 1957 through 1964, the spawning seasons of these species were observed to extend from mid-May to August or September.

2.-Red-ear sunfish, bluegills, and green sunfish usually nested in colonies, and mixed colonies containing two and, less frequently, all three of these species were not uncommon. Warmouths tended to be more solitary in their nest site selections.

3.-Results of lalıoratory experiments indicate that average functional life spans of bluegill, green sunfish, and warmouth gametes are approximately 1 hour for ova and 1 minute for spermatozoa. The brief functional life spans of spermatozoa are undoubtedly important in reducing hybridization caused by sperm clriftage.

4.-Gametes stripped from the four species were paired in 16 different combinations to produce zygotes representing 12 kinds of $F_{1}$ liybrids and the four parental species. IV o $\mathrm{x} B$ q $^{1}$ and IV o $x \mathrm{R}$ \% crosses were 100 percent lethal and the $\mathrm{W}$ \& $\times \mathrm{G}$ ? cross was partially lethal. Based on the percent-

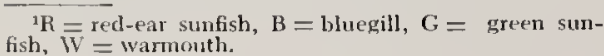

ages of zygotes that hatched and developed into normal-appearing fry, the viability of each of the remaining nine kinds of hybrids was not significantly different from that of its maternal parent. $\mathrm{B}$ o $\mathrm{R}$ \% and $\mathrm{G}$ o $\mathrm{R}$ ? hybrid fry were significantly longer bodied than pure red-ear fry of comparable ages. The other eiglst kinds of lyybrid fry were not significantly different in length from their respective maternal parent fry of comparable ages.

5.-Alpha temperature thresholds of development for red-ear sunfish, bluegills, green sunfish, and nine kinds of hybrids were not significantly different from one another. The mean alpha threshold for all 12 kinds of fishes was $18.3^{\circ}$ C. $\left(64.9^{\circ}\right.$ F. $)$. Approximately 280 developmental units (degree-hours of effective temperature) centigrade scale or 500 units Falrenheit scale were necessary for 50-percent hatching.

6.-Adult males of one species and adult females of another species were isolated in ponds to determine wlich of the 12 possible crosses may occur in nature. Thirty-four such experiments were conducted. Only Ro x Go , $\mathrm{G} \delta \mathrm{x} \mathrm{B}$ \% , and $\mathrm{W} \delta \mathrm{x} \mathrm{G}$ \& crosses (two, two, and one experiment, respectively) produced large $F_{1}$ hybrid populations. Female blucgills successfully spawned with red-ear males whose opercular talss had been removed (one experiment). Spawning did not occur in ponds containing normal redear males and femalc bluegills (five experiments). Results of the remaining 23 experiments were either negative or inconclusive.

7.-Large numbers of each of the 10 kinds of viable $F_{1}$ lybbrids were stocked in ponds, and after they grew to maturity, the sex ratio and fecundity exhibited by each population were investigated. $\mathrm{R}$ \& $\mathrm{B}$ ㅇ, $\mathrm{B}$ o $\mathrm{R}$ 의, and $\mathrm{B} \hat{\circ}$ $\mathrm{G}$ \& were 97 percent males; $\mathrm{W}^{\top} \delta \mathrm{G}$ ㅇ was 84 percent males; $\mathrm{R}$ \% $\mathrm{G}$ \%, $\mathrm{G}$ \% $\mathrm{B}$ ? , and $B$ o IV? were approximately 70 percent males; $\mathrm{G} \& \mathrm{R} q$ and $\mathrm{R}$ \% $\mathrm{W}$ \% 
were 50 percent males; and $\mathrm{G}$ \& $\mathrm{W}$ \% were only 16 percent males. When in ponds which contained either no other fishes or only hybrid crappies, only three ( $\mathrm{R} \delta \mathrm{B}$ \% , $\mathrm{B}$ of $\mathrm{R}$ 으, and $\mathrm{B} \delta \mathrm{G}$ \%) of the 10 kinds of viable $F_{1}$ hybrids failed to produce abundant $F_{2}$ generations. $\mathrm{R} \delta \mathrm{G}$ ㅇ, $\mathrm{G} \delta \mathrm{B}$ 을 and $\mathrm{B} \delta \mathrm{W}$ 우 $F_{1}$ hybrids were also stocked in ponds containing largemouth bass. These three kinds of $\mathrm{F}_{1}$ lybbrids were unable to produce abundant $F_{2}$ generations when in combination with largemouths although they did so in ponds where largemouth bass were absent.

8. $-I V$ o $\mathrm{G}$ ㅇ $\mathrm{F}_{2}$ hybrids isolated in one pond and $\mathrm{G} \delta \mathrm{IV} q \mathrm{~F}_{2}$ hybrids isolated in another pond produced abundant $\mathrm{F}_{3}$ generations. Thirteen other crosses involving $F_{1}$ hybrids were successful. Free-swimming fry from six of these were sacrificed because ponds were not available in which to stock them. Young from the other seven crosses were reared to 1 or more years of age in ponds, and successful reproduction occurred in three ponds.

9.-Equal numbers of relatively equal-sized $\mathrm{G} \hat{\mathrm{S}} \mathrm{R}$ q $\mathrm{F}_{1}$ hybrids, green sunfish, and red-ear sunfish were stocked in one pond, and $\mathrm{B} \not \mathrm{G}$ o $\mathrm{F}_{1}$ hybrids and green sunfish were stocked in another pond. When fishes in both ponds were poisoned at later dates, the average increases in total lengths of the hybrids were not significantly different from those of their parental species.

10.-The hemoglobin patterns in vertical starch gel electrophoresis of $\mathrm{B}$ o $\mathrm{W}$ \% , $\mathrm{G}$ \& $\mathrm{W}$ \% and $\mathrm{W}$ \& $\mathrm{G}$ \% $\mathrm{F}_{1}$ liybrids show marked differences from those of their parental species. The hybrid hemoglobins have better gas transport properties than those of the parental species, and in this respect these three hybrids are believed to exhibit hybrid vigor. The electrophoretic pattern of the hemoglobins of each of the other seven hybrids is identical to that obtained by mixing equal amounts of hemoglobins of the two parental species.

11.- $\mathrm{F}_{1}$ hybrid sunfishes appear to be highly vulnerable to capture by hook-and-line fishing. Creel censuses indicate that large populations of lhybrids can be almost completely eliminated in only a few days when subjected to moderate fishing pressure. 


\section{LITERATURE CITED}

Alderdice, D. F., W. P. Wickett, and I. R. Brett. 1958. Some effects of temporary exposure to low dissolved oxygen levels on Pacific salmon eggs. Jourmal of the Fisheries liesearch Board of Canada 15(2): 229-250.

Allee, II: C., Alfred F. Emerson, Orliudo Park, Thomas Park, and Karl P. Schmidt. 1949. Principles of animal ecology. IV. B. Saunders Company, Philadelphia and London. 837 p.

Anderson, Edgar. 1953. 1ntrogressive hybridization. Biological Reviews of the Cambridge Philosophical Society 28(3):280307.

Bailey, Reeve M. 1960a. Pisees (zoology), 1. 242-243. In Encylopedia of seience and technology. Volume 10. McGraw-Hill Book Company, Inc.. New Iork.

Chairman. 1960b. A list of common and scientific names of fishes from the United States and Canada. Second ed. American Fisheries Soeiety Special Publication 2. 102 p.

- and Karl F. Lagl'r. 1938. An analysis of hybriclization in a population of stunted sunfishes in New lork. Michigan Academy of Science, Arts, and Letters Papers for 1937, 23:577-606.

Bennett, George IV. 1958. Aquatic biology, p. 163-178. In A century of biological research. Illinois Natural History Survey Bulletin 27(2):85-234

-1962. Management of artificial lakes and ponds. Reinhold Publishing Coporation, New York. 283 p.

- David H. Thompson, and Sam A. Parr. 1940. Lake management reports, 4. A second year of fisheries investigations at Fork Lake, 1939. 1llinois Natural History Survey Biological Notes 14. $24 \mathrm{p}$.

Branson, Branley A., and George A. Moore. 1962. The lateralis components of the acoustico-lateralis system in the sunfish family Centrarchidae. Copeia (1):1-108.

Bright, William Milton. 1937. Spermatogenesis in sunfish. Ph.D. Thesis. University of Illinois, Urbana. $49 \mathrm{p}$.

Childers, William F., and George Wr. Bennett. 1961. Ilybridization between three specics of sunfish (Lepomis). Illinois Natural History Survey Biological Notes 46. $15 \mathrm{p}$.

Cross, Frank Bernard, and George A. Moore. 1952. The fishes of the Poteau River, Oklahoma and Arkansas. American Midland Naturalist $47(2): 396-412$.

Crossman, E. J., and Keen Buss. 1965. Hybridization in the family Esocidae. Journal of the Fisheries Research Board of Canada $22(5): 1261-1292$.
Dirlington, C. D. 1958. Evolution of genetic systems. Second ed. Oliver \& Boyd, London. $265 \mathrm{p}$.

Darwin, Charles. 1897. The origin of species. Reprint of sixtl ed. Volume 2. D. Appleton and Company, New York. 339 p. Fisher, lionald A., and Frank Yates. 1963. Statistieal tables for biological, agricultural and medical research. Sixth ed. Hafner Publishing Company, lnc., New York. $146 \mathrm{p}$.

Forbes, Stephen Alfred, and Robert Earl Richardson. 1920. The fishes of 1llinois. Second ed. Illinois Natural History Survey, Urbana. $357 \mathrm{p}$.

Grecley, J. R., and S. C. Rishop. 1933. Fishes of the npper Hudson watershed, p. 64-101. In A biological survey of the upper Hudson watershed. New York Conservation Department Biological Survey, Supplemental to Twenty-Second Annual Report, 1932, Volume 7.

Haldane, J. B. S. 1922. Sex ratio and unisexual sterility in hybrid animals. Journal of Cenetics 12(2):101-109.

Halc, E. B. 1956. Social facilitation and forchrain function in maze performance of green sunfish, Lepomis cyanellus. Physiological Zoology 29( 2):93-107.

Heiser, Charles B., Jr. 1949. Natural hybridization with particular reference to introgression. Botanieal Review 15(10):645687.

Hublss, Carl L. 1920. Notes on hybrid sumfishes. Aquatic Life 5(9): 101-103.

-1926. A clueck-list of the fishes of the Great Lakes and tributary waters, witl nomenclatorial notes and analytical keys. University of Michigan Museum of Zoology Miscellaneous Publication 15. $85 \mathrm{p}$.

1955. Hybridization hetween fish speeies in nature, Systematic Zoology $4(1): 1-20$.

- and Laura C. Hubbs. 1931. Inereased growth in hybrid sunfishes. Michigan Academy of Science, Arts and Letters Papers for 1930, 13:291-301.

- and - 1932. Experimental verification of natural hyloridization between distinet genera of sunfishes. Michigan Academy of Seience, Arts and Letters Papers for 193I, 15:427-437.

per and 1933. The increased growtl, predominant maleness, and apparcnt infertility of hybrid sunfishes. Michigan Academy of Science, Arts and Letters Papers for 1932, 17:613-641.

, and A. I. Ortenburger. 1929. Further notes on the fishes of Oklahoma with description of new species of Cyprinidae, p. 17-43. In University of Oklahoma Bul- 
letin, new series 434. (Also listed as University of Oklahoma Biological Survey Publications $1(2): 17-43$.)

Hunter, John R. 1963. The reproductive behavior of the green sunfish, Lcpomis cyancllus. Zoologica 48(1):13-24.

Kendeigh, S. Charles. 1961. Animal ecology. Prentice-Hall, Inc., Englewood Cliffs, New Jersey. 468 p.

Krumlolz, Louis A. 1950. Further observations on the use of hybrid sunfish in stocking small ponds. American Fisheries Socicty Transactions for 1949, 79:112-124.

Larimore, R. Weldon. 1957. Ecological life history of the warmouth (Centrarchidae). llinois Natural History Survey Bulletin 27( I) :1-83.

- and Philip IV. Smith. 1963. The fishes of Champaign County, lllinois, as affected by 60 years of stream changes. 1llinois Natural History Survey Bulletin 28: ( 2):299-382.

Lopinot, Al. 1961. The red-ear sunfish. 1llinois Wildlife 17( 1):3-4.

Manwell, Clyde, C. M. Ann Baker, and IVilliam Childers. 1963. The genetics of hemoglobin in hybrids-1. A molecular hasis for hybrid vigor. Comparative Biochemistry and Physiology 10:103-120.

Marler, P. 1957. Specific distinctiveness in the communication signals of birds. Behaviour 11(1):13-39.

McAtee, W. L., and A. C. Weed. 1915. First list of the fishes of the vicinity of Plummers Island, Maryland. Biological Socicty of Washington Proceedings 28:1-14.

Miller, Heten Carter. 1963. The behavior of the pumpkinseed sunfish, Lepomis gibbosus (Linneaus), with notes on the behavior of other species of Lepomis and the pigmy sunfish, Elassoma cvergladei. Behaviour $22(1-2): 88-151$.

Miller, Robert Rush. 1958. Origin and affinities of the freshwater fish fauna of westcin North America, p. 187-222. In Carl L. Hubbs, editor, Zoogeography. American Association for the Adrancement of Science Publication 5I, Washington, D. C. 509 p.

O'Donnel], D. John. 1935. Annotated list of the fishes of Illinois. Illinois Natural History Survey Bulletin 20(5):473-491.
Radcliffe, Lewis, 1914. A hybrid centrarchid. Copeia ( 7):26-28.

Raney, Edward C. 1940. Reproductive activities of a hybrid minnow, Notropis cornutus $\mathrm{x}$ Notropis rubcllus. Zoologica 25 (24) :361-367.

Ricker, William E. 1948. Hybrid sunfish for stocking small ponds. American Fisheries Society Transactions for 1945, 75:8496.

Robcrts, Franklin L. 1964. A chromosome study of twenty species of Centrarchidae. Journal of Morphology 115(3):401-417.

Ross, Herbert H. 1958. Evidence suggesting a hybrid origin for certain leafhopper species. Evolution 12(3):337-346.

Schuchert, Charles, and Carl O. Dunbar. 1941. A textbook of geology. Part IIhistorical geology. Fourth ed. John IViley \& Sons, lnc., New York. 544 p.

Shelford, Victor E. 1927. An experimental investigation of the relations of the codling moth to weather and climate. Illinois Natural History Survey Bulletin 16(5):311440.

Smitherman, R. Oneal, and F. Eugene Hester. 1962. Artificial propagation of sunfishes, with meristic comparisons of thrce species of Lcpomis and five of their hybrids. American Fisheries Society Transactions 91(4): 333-341.

Slastenenko, E. P. 1957. A list of natural fish liybricls of the world. Publication of the Hydrobiological Research Institute, Faculty of Science, University of Istanbul. Series B. 4(2-3): 76-97.

Stebbins, G. Ledyard. 1959. The role of hybridization in evolution. American Philosophical Society Proceedings 103:231-251.

Swingle, H. S. 1949. Some recent developments in pond management. North American Wildlife Conference Transactions 14: 295-312.

. 1956. A repressive factor controlling reproduction in fishes. Eighth Pacific Science Congress Proccedings 3A:865-87I.

Tinbergen, N. 1951. The study of instinct. Oxford University Press, London. $228 \mathrm{p}$.

Trautman, Milton B. 1957. The fishes of Ohio. The Ohio State University Press, Columbus. 683 p.

Listed below are some recent papers on hylorid sunfishes. These papers have been published since the completion of the manuscript of this bulletin.

Birdsong, Ray S., and Ralph W. Yerger. 1967. A natural population of hylorid sunfishes: Lepomis macrochirus $x$ Chacnobryttus gulosus. Copeia (1):62-71.

Childers, William F., and George WV. Bennett. 1967. Hook-and-line yield of largemoutl biss and redear $x$ green sunfish hybrids in a one-acre pond. Progressive Fish-Culturist $29(1): 27-35$.

Clark, Francis IT., aud Miles H. A. Keenlcyside. 1967. Reproductive isolation between the sunfish Levomis gihbosus and L. macrochirus. Journal of the Fisheries liesearch Board of Canada 24(3):495-514.

Vest, Jerry L., and F. Eugene Hester. 1966. Intergeneric hyloridization of centrarchids. Transactions of the Americun Fisheries Socicty $95(3): 280-288$. 


\section{APPENDIX}

Table A1.-Partial chemical analysis of water taken August 2, 1963, from the well on Parkhill's Lake Park Subdivision Number Two, approximately 3 miles south of Champaign, III. The water was aerated and filtered through activated charcoal for 1 week prior to the analysis. The water had no measurable color or odor. The $\mathrm{pH}$ was 8.8 . The analysis was made by the Illinois Water Survey.

Chemical Composition

Parts Per Million

Iron (total)

Caleium

Trace

Magnesium

Chloride

Phenothaline alkalinity (as $\mathrm{CaCO}_{3}$ )

Methyl orange alkalinity (as $\mathrm{CaCO}_{3}$ )

Hardness (as $\mathrm{CaCO}_{3}$ )

Total dissolved minerals

Table A2,-Experiment W1: duration of fertility of activated gametes from one pair of warmouths. *

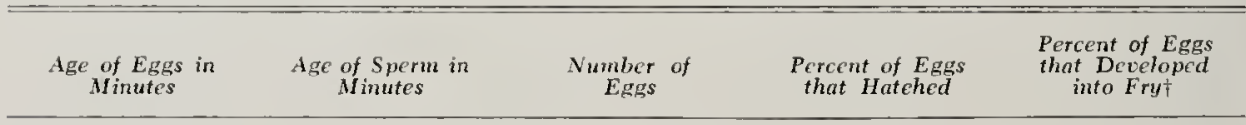

Aging of Sperm and Eggs

$\begin{array}{rrrrr}0.75 & 0.25 & 93 & 47 & 46 \\ 3.15 & 2.75 & 211 & 11 & 10 \\ 5.55 & 5.25 & 102 & 0 & 0 \\ 8.45 & 7.75 & 149 & 0 & 0 \\ 10.35 & 10.25 & 86 & 0 & 0\end{array}$

- The temperature at time of fertilization was $27.8^{\circ}$ C. $\left(82.0^{\circ}\right.$ F. $)$. During the entire experiment, 132 hours, the temperature ranged from $26.1^{\circ}$ to $27.8^{\circ} \mathrm{C}\left(79.0^{\circ}\right.$ to $82.0^{\circ} \mathrm{F}$.) and averaged $27.2^{\circ} \mathrm{C} .\left(80.9^{\circ} \mathrm{F}.\right)$. Fry were free swimming. Only normal fry are included in this figure.

Table A3.-Experiment W2: duration of fertility of activated gametes from one pair of warmouths."

\begin{tabular}{|c|c|c|c|c|}
\hline $\begin{array}{c}\text { Age of Eggs in } \\
\text { Mfinutes }\end{array}$ & $\begin{array}{c}\text { Age of Sperm in } \\
\text { Minutes }\end{array}$ & $\begin{array}{c}\text { Number of } \\
\text { Eggs }\end{array}$ & $\begin{array}{l}\text { Pereent of Eggs } \\
\text { that Hatched }\end{array}$ & $\begin{array}{l}\text { Percent of Eggs } \\
\text { that Developed } \\
\text { into Fryt }\end{array}$ \\
\hline
\end{tabular}

Aging of Sperm and Eggs

$\begin{array}{rrrrr}0.75 & 0.25 & 25 & 42 & 35 \\ 3.15 & 2.75 & 20 & 0 & 0 \\ 5.55 & 5.25 & 48 & 0 & 0 \\ 8.45 & 7.75 & 29 & 0 & 0 \\ 10.55 & 10.25 & 37 & 0 & 0\end{array}$

-The temperature at time of fertilization was $27.8^{\circ} \mathrm{C} .\left(82.0^{\circ} \mathrm{F}.\right)$. During the entire experiment, 128 hours, the temperature ranged from $26.1^{\circ}$ to $27.8^{\circ} \mathrm{C} .\left(79.0^{\circ}\right.$ to $82.0^{\circ} \mathrm{F}$.) and averaged $27.2^{\circ} \mathrm{C} .\left(80.9^{\circ} \mathrm{F} .\right)^{\circ}$

tFry were free swimming. Only normal fry are included in this figure. 
Table A4.--Experiment W3: duration of fertility of activated eggs from a single female warmouth. Sperm used in this experiment were from a single male."

\begin{tabular}{|c|c|c|c|c|}
\hline $\begin{array}{l}\text { Age of Eggs in } \\
\text { Minutes }\end{array}$ & $\begin{array}{c}\text { Age of Sperm in } \\
\text { Minutes }\end{array}$ & $\underset{\substack{\text { Number of } \\
\text { Eggs }}}{ }$ & $\begin{array}{l}\text { Percent of Eggs } \\
\text { that Hatched }\end{array}$ & $\begin{array}{l}\text { Percent of Eggs } \\
\text { that Deceloped } \\
\text { into Fryt }\end{array}$ \\
\hline & & Aging of Egg & & \\
\hline 0.50 & 0 & 39 & 100 & 95 \\
\hline 30.00 & 0 & 79 & 92 & 90 \\
\hline 60.00 & 0 & 91 & 72 & 70 \\
\hline 120.00 & 0 & 81 & 49 & 48 \\
\hline 180.00 & 0 & 89 & 7 & 2 \\
\hline
\end{tabular}

- The temperature at time of fertilization was $27.2^{\circ}$ C. $\left(81.0^{\circ}\right.$ F. $)$. During the entire experiment, 100 hours, the temperature ranged from $26.1^{\circ}$ to $28.3^{\circ} \mathrm{C} .\left(79.0^{\circ}\right.$ to $83.0^{\circ} \mathrm{F}$.) and averaged $27.3^{\circ} \mathrm{C} .\left(81.1^{\circ} \mathrm{F} .\right)^{\circ}$.

Fry able to swim for short periods but not completely free swimming. Only normal fry are included in this figure.

Table A5.-Experiment W4: duration of fertility of activated eggs from a single female warmouth. Soerm used in this experiment were from a single male."

\begin{tabular}{|c|c|c|c|c|}
\hline $\begin{array}{l}\text { Age of Eggs in } \\
\text { Minutes }\end{array}$ & $\begin{array}{c}\text { Age of Sperm in } \\
\text { Minutes }\end{array}$ & $\underset{\text { Eggs }}{\text { Number of }}$ & $\begin{array}{l}\text { Percent of Eggs } \\
\text { that Hatched }\end{array}$ & $\begin{array}{l}\text { Percent of Eggs } \\
\text { that Developed } \\
\text { into Fryt }\end{array}$ \\
\hline & & Aging of $\mathrm{Eg}$ & & \\
\hline 0.50 & 0 & 89 & 89 & 73 \\
\hline 30.00 & 0 & 82 & 16 & 16 \\
\hline 60.00 & 0 & 81 & 44 & 41 \\
\hline 120.00 & 0 & 69 & 14 & 6 \\
\hline 180.00 & 0 & 89 & 0 & 0 \\
\hline
\end{tabular}

-The temperature at time of fertilization was $27.5^{\circ} \mathrm{C} \cdot\left(81.5^{\circ} \mathrm{F}\right.$. $)$. During the entire experiment, 125 hours, the temperature ranged from $26.4^{\circ}$ to $27.8^{\circ} \mathrm{C}\left(79.5^{\circ}\right.$ to $\left.82.0^{\circ} \mathrm{F}_{\text {. }}\right)$ and averaged $27.0^{\circ} \mathrm{C} .\left(80.6^{\circ} \mathrm{F}.\right)$.

$\dagger$ Fry were free swimming. Only normal fry are included in this figure. 
Table A6.-Experiment B I : duration of fertility of activated gametes from one pair of bluegills. :

\begin{tabular}{|c|c|c|c|c|}
\hline $\begin{array}{l}\text { Age of Eggs in } \\
\text { Minutes }\end{array}$ & $\begin{array}{c}\text { Age of Sperm in } \\
\text { Minutes }\end{array}$ & $\begin{array}{c}\text { Number of } \\
\text { Eggs }\end{array}$ & $\begin{array}{c}\text { Percent of Eggs } \\
\text { that Hatched }\end{array}$ & $\begin{array}{l}\text { Percent of Eggs } \\
\text { that Developed } \\
\text { into Fryt }\end{array}$ \\
\hline \multicolumn{5}{|c|}{ Aging of Sperm and Eggs } \\
\hline 1.00 & 0.25 & 48 & 50 & 33 \\
\hline 1.90 & 1.25 & 40 & 45 & 8 \\
\hline 2.80 & 2.25 & 38 & 18 & 18 \\
\hline 3.70 & 3.25 & 63 & 2 & 2 \\
\hline 4.60 & 4.25 & 42 & 0 & 0 \\
\hline 5.50 & 5.25 & 27 & 0 & 0 \\
\hline \multicolumn{5}{|c|}{ Aging of Eggs } \\
\hline 0.50 & 0 & 26 & 85 & 85 \\
\hline 30.00 & 0 & 44 & 75 & 68 \\
\hline 60.00 & 0 & 26 & 38 & 27 \\
\hline 120.00 & 0 & 59 & 22 & 10 \\
\hline 180.00 & 0 & 32 & 0 & 0 \\
\hline
\end{tabular}

- The temperature at time of fertilization was $23.3^{\circ}$ C. $\left(74.0^{\circ}\right.$ F.). During the entire experiment, 102 hours, the temperature ranged from $23.0^{\circ}$ to $27.2^{\circ} \mathrm{C} .\left(73.5^{\circ} \text { to } 81.0^{\circ} \mathrm{F} \text {.) and averaged } 25.3^{\circ} \mathrm{C} . \mathrm{C}^{\circ} .6^{\circ} \mathrm{F} .\right)^{\circ}$ Fry able to swim for short periods but not completely free swimming. Only normal fry are included in this figure.

Table A7.--Experiment B2: duration of fertility of activated gametes from one pair of bluegills.

\begin{tabular}{|c|c|c|c|c|}
\hline $\begin{array}{c}\text { Age of Eggs in } \\
\text { Minutes }\end{array}$ & $\begin{array}{c}\text { Age of Sperm in } \\
\text { Minutes }\end{array}$ & $\underset{\text { Eggs }}{\text { Number of }}$ & $\begin{array}{l}\text { Percent of Eggs } \\
\text { that Hatched }\end{array}$ & $\begin{array}{l}\text { Percent of Eggs } \\
\text { that Developed } \\
\text { into Fryt }\end{array}$ \\
\hline
\end{tabular}

Aging of Sperm and Eggs

$\begin{array}{lrrrr}1.00 & 0.25 & 44 & 82 & 64 \\ 1.90 & 1.25 & 34 & 53 & 44 \\ 2.80 & 2.25 & 38 & 5 & 5 \\ 3.70 & 3.25 & 22 & 0 & 0 \\ 4.60 & 4.25 & 23 & 0 & 0 \\ 5.50 & 5.25 & 37 & 0 & 0\end{array}$

-The temperature at time of fertilization was $23.6^{\circ} \mathrm{C} .\left(74.5^{\circ} \mathrm{F}\right.$.). During the entire experiment, 102 hours, the temperature ranged from $23.0^{\circ}$ to $27.2^{\circ} \mathrm{C} .\left(73.5^{\circ}\right.$ to $81.0^{\circ} \mathbf{F}$.) and averaged $25.3^{\circ} \mathrm{C} .\left(77.6^{\circ} \mathrm{F},\right)^{\circ}$ tFry able to swim for short periods but not completely free swimming. Only normal fry are included in this figure. 
Table A8.-Experiment B3: duration of fertility of activated eggs from one female bluegill. Sperm used in this experiment were from a single male."

\begin{tabular}{|c|c|c|c|c|}
\hline $\begin{array}{l}\text { Age of Eggs in } \\
\text { Minutes }\end{array}$ & $\begin{array}{c}\text { Age of Sperm in } \\
\text { Minutes }\end{array}$ & $\begin{array}{l}\text { Number of } \\
\text { Eggs }\end{array}$ & $\begin{array}{c}\text { Percent of Eggs } \\
\text { that Hatched }\end{array}$ & $\begin{array}{l}\text { Percent of Eggs } \\
\text { that Developed } \\
\text { into Fry }\end{array}$ \\
\hline \multicolumn{5}{|c|}{ Aging of Eggs } \\
\hline 0.50 & 0 & 96 & 96 & 96 \\
\hline 30.00 & 0 & 71 & 82 & 82 \\
\hline 60.00 & 0 & 59 & 51 & 51 \\
\hline 120.00 & 0 & 93 & 16 & 16 \\
\hline 180.00 & 0 & 44 & 20 & 20 \\
\hline
\end{tabular}

- The temperature at time of fertilization was $26.9^{3}$ C. $\left(80.5^{\circ}\right.$ F.). During the entire experiment, 98 hours, the temperature ranged from $26.1^{\circ}$ to $28.3^{\circ} \mathrm{C} .\left(79.0^{\circ}\right.$ to $83.0^{\circ} \mathrm{F}$.) and averaged $27.3^{\circ} \mathrm{C} .\left(81^{\circ} 1^{\circ} \mathrm{F}.\right)$

Fry able to swim for short periods but not completely free swimming. Only normal fry are included in this figure.

Table A9.-Experiment B4: duration of fertility of activated eggs from a single female bluegill. Sperm used in this experiment were from a single male."

\begin{tabular}{|c|c|c|c|c|}
\hline $\begin{array}{c}\text { Age of Eggs in } \\
\text { Minutes }\end{array}$ & $\begin{array}{c}\text { Age of Sperm in } \\
\text { Minutes }\end{array}$ & $\begin{array}{c}\text { Number of } \\
\text { Eggs }\end{array}$ & $\begin{array}{l}\text { Percent of Eggs } \\
\text { that Hotched }\end{array}$ & $\begin{array}{l}\text { Perccnt of Eggs } \\
\text { that Developed } \\
\text { into Fryt }\end{array}$ \\
\hline \multicolumn{5}{|c|}{ Aging of Eggs } \\
\hline 0.50 & 0 & 88 & 65 & 61 \\
\hline 30.00 & 0 & 28 & 28 & 28 \\
\hline 60.00 & 0 & 38 & 32 & 32 \\
\hline 120.00 & 0 & 44 & 23 & 23 \\
\hline 180.00 & 0 & 48 & 4 & 0 \\
\hline
\end{tabular}

-The temperature at time of fertilization was $23.9^{\circ}$ C. $\left(75.0^{\circ}\right.$ F.). Doring the entire experiment, 138 hours, the temperature ranged from $22.8^{\circ}$ to $25.0^{\circ} \mathrm{C} .\left(73.0^{\circ}\right.$ to $77.0^{\circ} \mathrm{F}$.) and averaged $24.2^{\circ} \mathrm{C} .\left(75.5^{\circ} \mathrm{F}\right.$. ) tFry able to swim for short periods hut not completely free swimming. Only normal fry are included in this figure. 
Table A1O.-Experiment GI: duration of fertility of activated gametes from one pair of green sunfish. *

Age of Eggs in
Minutes

Aging of Sperm and Eggs

$\begin{array}{lrrrr}1.00 & 0.25 & 40 & 52 & 50 \\ 1.90 & 1.25 & 32 & 6 & 6 \\ 2.80 & 2.25 & 34 & 1 & 1 \\ 3.70 & 3.25 & 31 & 0 & 0 \\ 4.60 & 4.25 & 43 & 0 & 0 \\ 5.50 & 5.25 & 38 & 5 & 5\end{array}$

Aging of Eggs

$\begin{array}{rrrrr}0.50 & 0 & 33 & 91 & 88 \\ 30.00 & 0 & 57 & 24 & 23 \\ 60.00 & 0 & 74 & 8 & 7 \\ 120.00 & 0 & 49 & 4 & 2 \\ 180.00 & 0 & 27 & 7 & 4\end{array}$

- The temperature at time of fertilization was $23.6^{\circ} \mathrm{C} .\left(74.5^{\circ} \mathrm{F}\right.$.). During the entire experiment, 185 hours, the temperature ranged from $22.8^{\circ}$ to $25.0^{\circ} \mathrm{C} .\left(73.0^{\circ}\right.$ to $77.0^{\circ} \mathrm{F}$.) and averaged $24.2^{\circ} \mathrm{C} .\left(75.6^{\circ} \mathrm{F}.\right)$. tFry able to swim for short periods but not completely free swimming. Only normal lry are included in this figure.

Table Al1.-Experiment G2: duration of fertility of activated gametes from one pair of green sunfish.

\begin{tabular}{|c|c|c|c|c|}
\hline $\begin{array}{c}\text { Agc of Eggs in } \\
\text { Minutes }\end{array}$ & $\begin{array}{c}\text { Age of Sperm in } \\
\text { Minutes }\end{array}$ & $\begin{array}{c}\text { Vumber of } \\
\text { Eggs }\end{array}$ & $\begin{array}{c}\text { Percent of Esgs } \\
\text { that IIatched }\end{array}$ & $\begin{array}{l}\text { Percent of Eggs } \\
\text { that Decloped } \\
\text { into Fryt }\end{array}$ \\
\hline
\end{tabular}

Aging of Sperm and Eggs

$\begin{array}{rrrrr}2.25 & 0.25 & 79 & 52 & 47 \\ 3.15 & 1.25 & 57 & 19 & 18 \\ 4.05 & 2.25 & 55 & 2 & 2 \\ 4.95 & 3.25 & 81 & 0 & 0 \\ 5.85 & 4.25 & 71 & 1 & 1 \\ 6.75 & 5.25 & 74 & 0 & 0\end{array}$

Aging of Eggs

$\begin{array}{rrrrr}0.50 & 0 & 31 & 32 & 32 \\ 30.00 & 0 & 39 & 41 & 36 \\ 60.00 & 0 & 78 & 26 & 23 \\ 120.00 & 0 & 46 & 13 & 13 \\ 180.00 & 0 & 70 & 7 & 6\end{array}$

The temperature at time of fertilization was $23.6^{\circ}$ C. $\left(74.5^{\circ} \mathrm{F}.\right)$. During the entire experiment, 185 hours, the temperature ranged from $22.8^{\circ}$ to $25.0^{\circ} \mathrm{C} .\left(73.0^{\circ}\right.$ to $77.0^{\circ} \mathrm{F}$.) and averaged $24.2^{\circ} \mathrm{C}$. $\left(75.6^{\circ} \mathrm{F}.\right)$.

tFry able to swim for short periods but not completely free swimming. Only normal fry are included in this figure. 
Table A 12.-Experiment G3: duration of fertility of activated gametes from one pair of green sunfish.

\begin{tabular}{|c|c|c|c|c|}
\hline $\begin{array}{c}\text { Agc of Eggs in } \\
\text { Minutes }\end{array}$ & $\begin{array}{c}\text { Age of Sperm in } \\
\text { Minutes }\end{array}$ & $\begin{array}{c}\text { Number of } \\
\text { Eggs }\end{array}$ & $\begin{array}{l}\text { Percent of Eggs } \\
\text { that Hatched }\end{array}$ & $\begin{array}{l}\text { Percent of Eggs } \\
\text { that Doveloped } \\
\text { into Fryt }\end{array}$ \\
\hline
\end{tabular}

Aging of Sperm and Eggs

\begin{tabular}{|c|c|c|c|}
\hline 1.00 & 0.25 & 44 & 36 \\
\hline 1.90 & 1.25 & 52 & 25 \\
\hline 2.80 & 2.25 & 16 & 0 \\
\hline 3.70 & 3.25 & 111 & 5 \\
\hline 4.60 & 4.25 & 25 & 4 \\
\hline 5.50 & 5.25 & 46 & 2 \\
\hline
\end{tabular}

Aging of Eggs

$\begin{array}{rrrrr}0.50 & 0 & 41 & 36 & 34 \\ 30.00 & 0 & 75 & 39 & 39 \\ 60.00 & 0 & 31 & 22 & 22 \\ 120.00 & 0 & 26 & 54 & 50 \\ 180.00 & 0 & 26 & 42 & 42\end{array}$

-The temperature at time of fertilization was $24.4^{\circ}$ C. $\left(76.0^{\circ}\right.$ F.). During the entire experiment, 118 hours, the temperature ranged from $23.0^{\circ}$ to $27.2^{\circ} \mathrm{C} .\left(73.5^{\circ}\right.$ to $81.0^{\circ} \mathrm{F}$.) and averaged $25.1^{\circ} \mathrm{C} .\left(77.2^{\circ} \mathrm{F} .\right)^{\circ}$

Fry able to swim for short periods but not eompletely free swimming. Only normal iry are included in this figure.

Table A13.-Experiment G4: duration of fertility of activated eggs from a single female green sunfish. Sperm used in this experiment were from a single male."

\begin{tabular}{ccccc}
\hline $\begin{array}{c}\text { Age of Eggs in } \\
\text { Minutes }\end{array}$ & $\begin{array}{c}\text { Age of Spcrm in } \\
\text { Minutes }\end{array}$ & $\begin{array}{c}\text { Number of } \\
\text { Eggs }\end{array}$ & $\begin{array}{c}\text { Percent of Eggs } \\
\text { that Hatched }\end{array}$ & $\begin{array}{c}\text { Perecht of Eggs } \\
\text { that Derfoped } \\
\text { into Fry }\end{array}$ \\
\hline \multicolumn{7}{c}{ Aging of Eggs } & & \\
0.50 & 0 & 36 & 75 & 75 \\
30.00 & 0 & 51 & 53 & 53 \\
60.00 & 0 & 33 & 48 & 48 \\
120.00 & 0 & 31 & 26 & 26 \\
180.00 & 0 & 48 & 10 & 8
\end{tabular}

- The temperature at time of f(rtilization was $26.9^{\circ} \mathrm{C} .\left(80.5^{\circ} \mathrm{F}.\right)$. During the entire experiment, 101 hours, the temperature ranged from $26.1^{\circ}$ to $28.3^{\circ} \mathrm{C} .\left(79.0^{\circ}\right.$ to $83.0^{\circ} \mathrm{F}$. $)$ and averaged $27.3^{\circ} \mathrm{C} .\left(81.1^{\circ} \mathrm{F}.\right)$.

Fry able to swim for short periods but not completely free swimming. Only normal fry are included in this figure. 

는

$\overline{6}$

牙

$\div \circ$

$\stackrel{\infty}{\mathrm{m}}$

站

วิำ

no

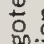

ì

믕

空

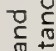

\&

웅

जें

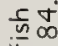

热

$\llcorner\circ$

in

div

t)

ट

$\varepsilon$

응

वृ:

है

능츤

는

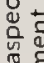

है

$\ddot{\sim}$

t

है

.

⿶凵户

I.

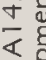

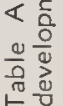

@़

$\stackrel{\infty}{-1}$

89

点

ำ

¿노

2z

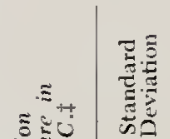

跑

¿

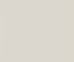

ะี

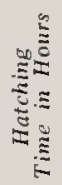

हैं

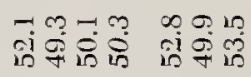

격웅

ตें

$\infty_{1}^{\infty}$

$\infty_{1}^{\infty}$

?

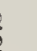

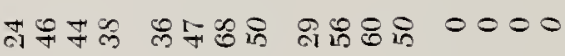

जा 10 


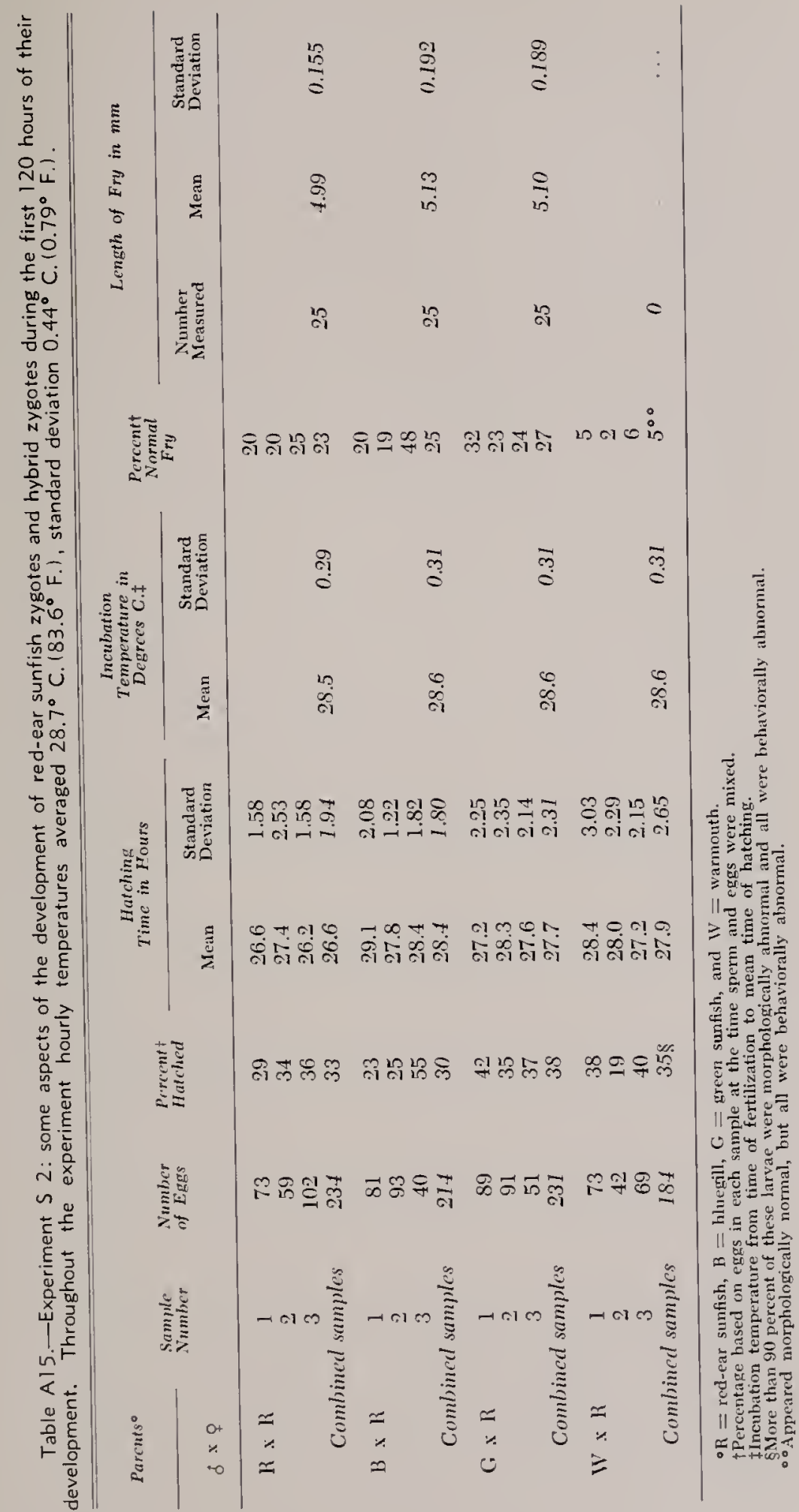




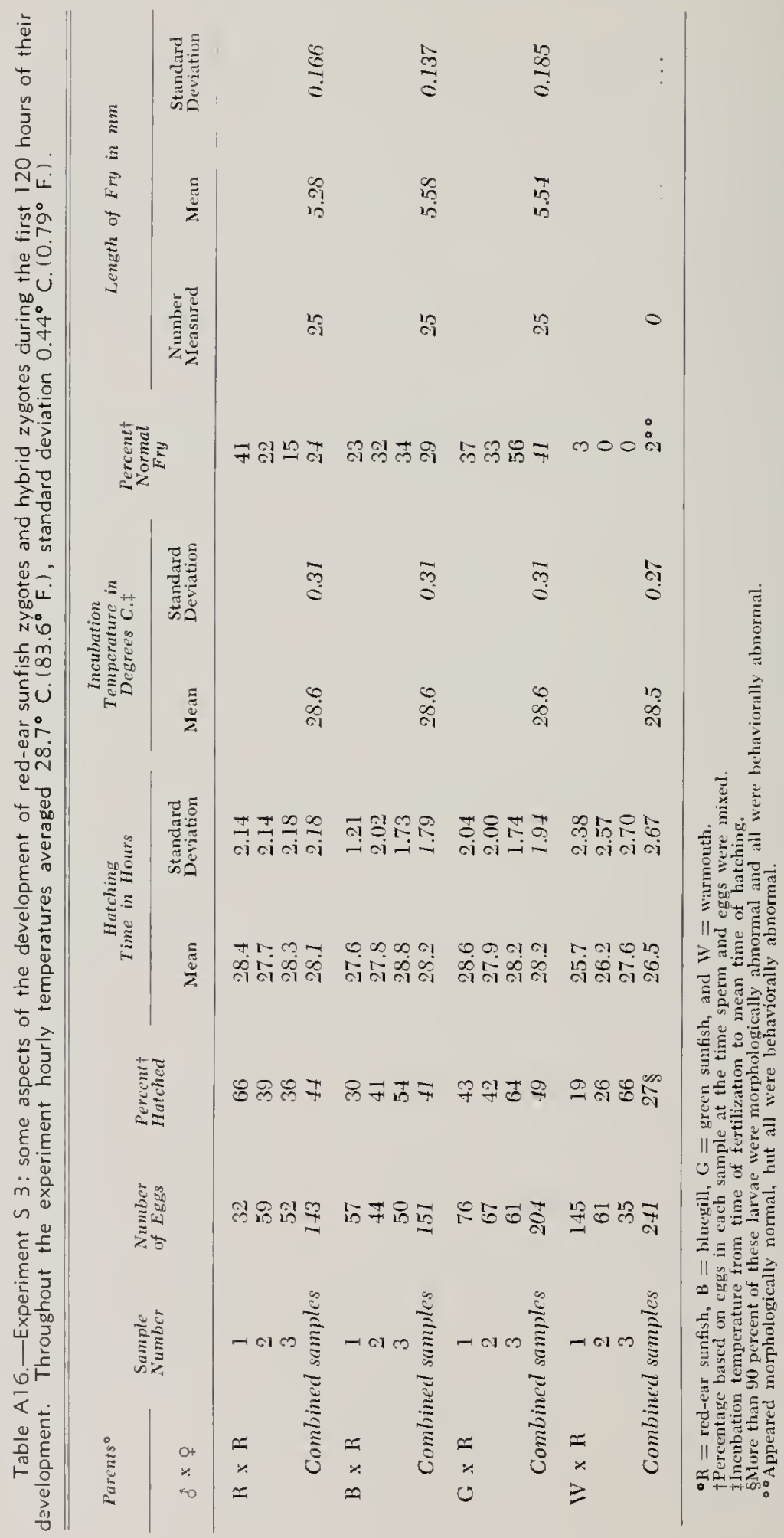




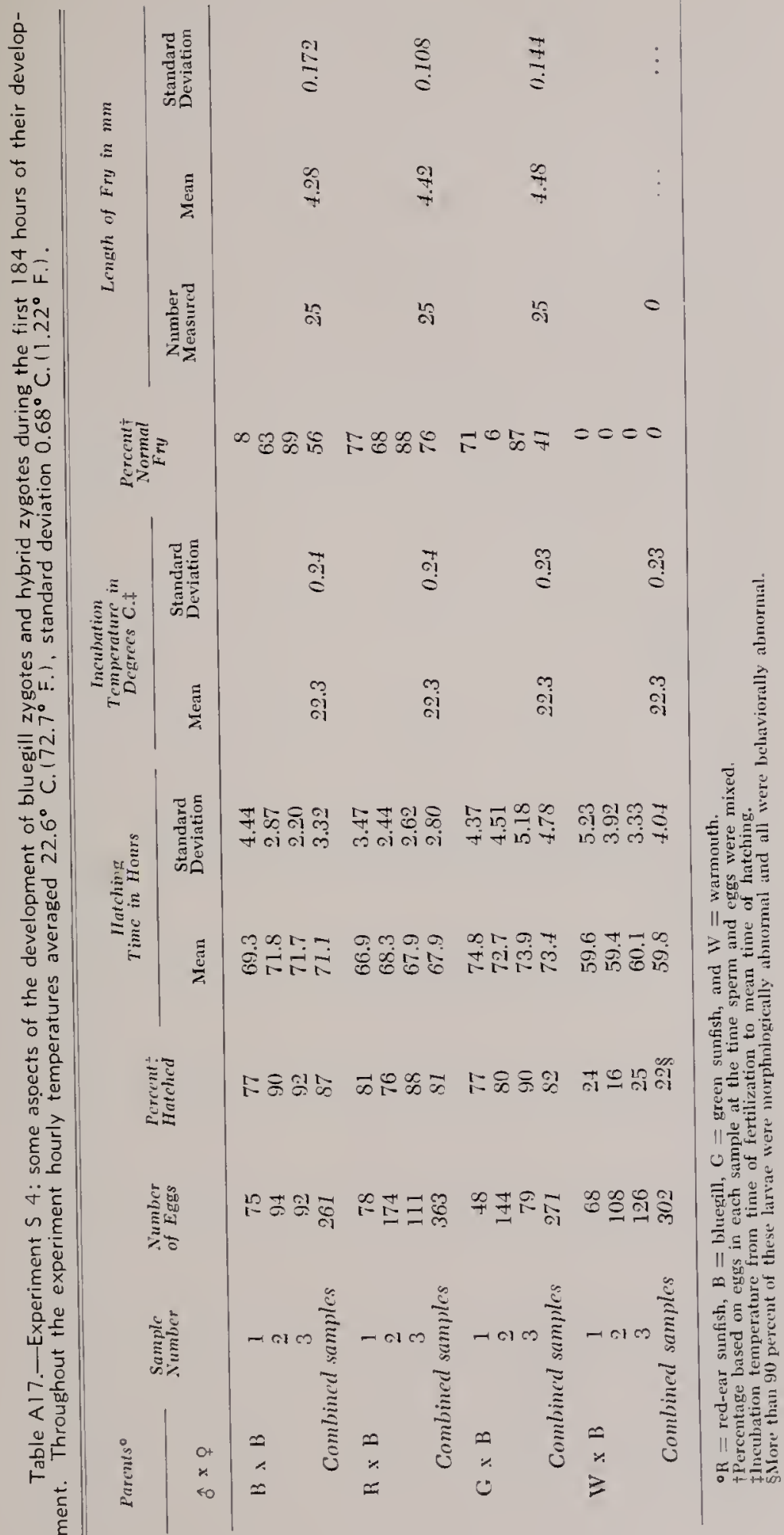




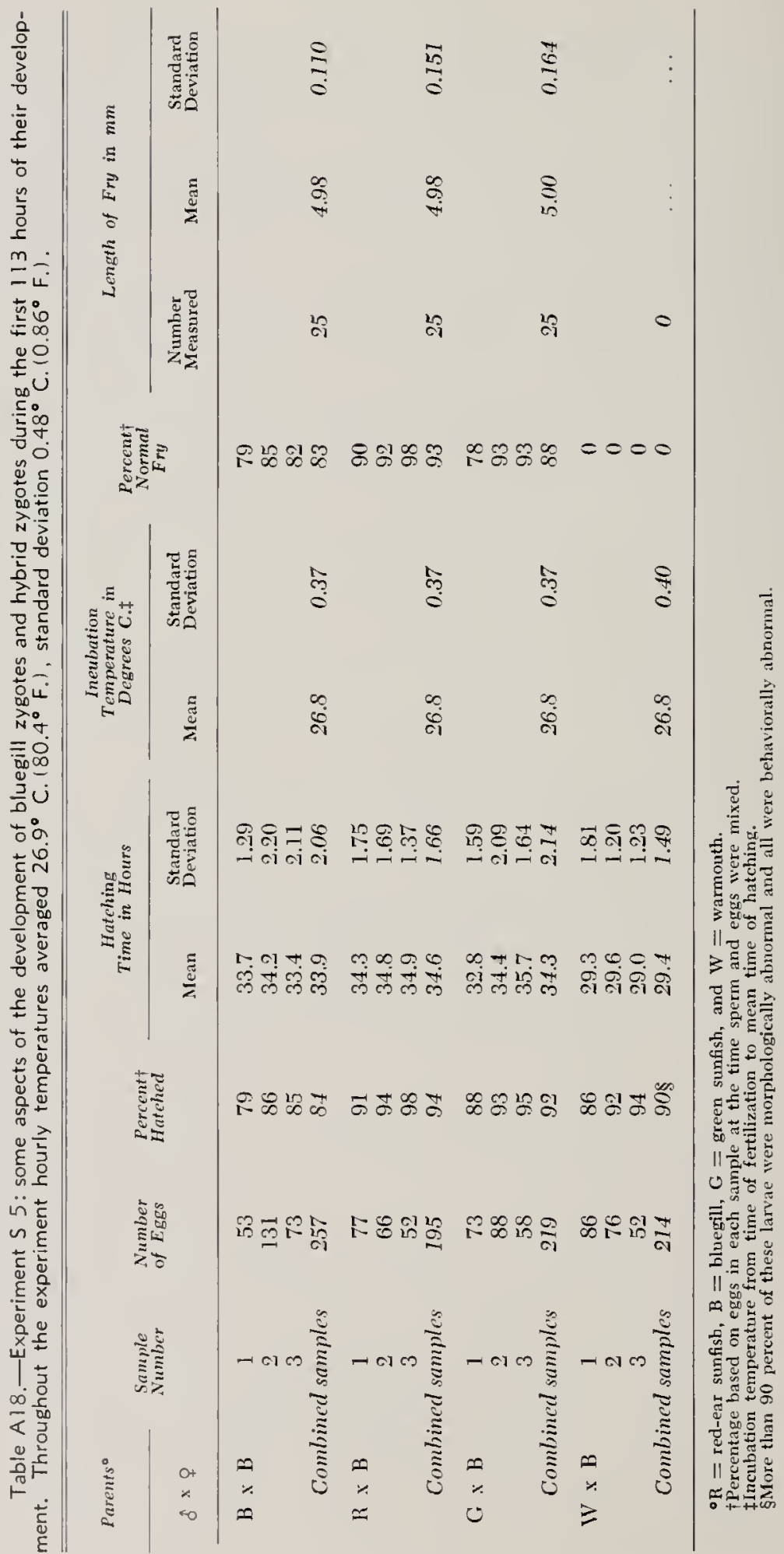




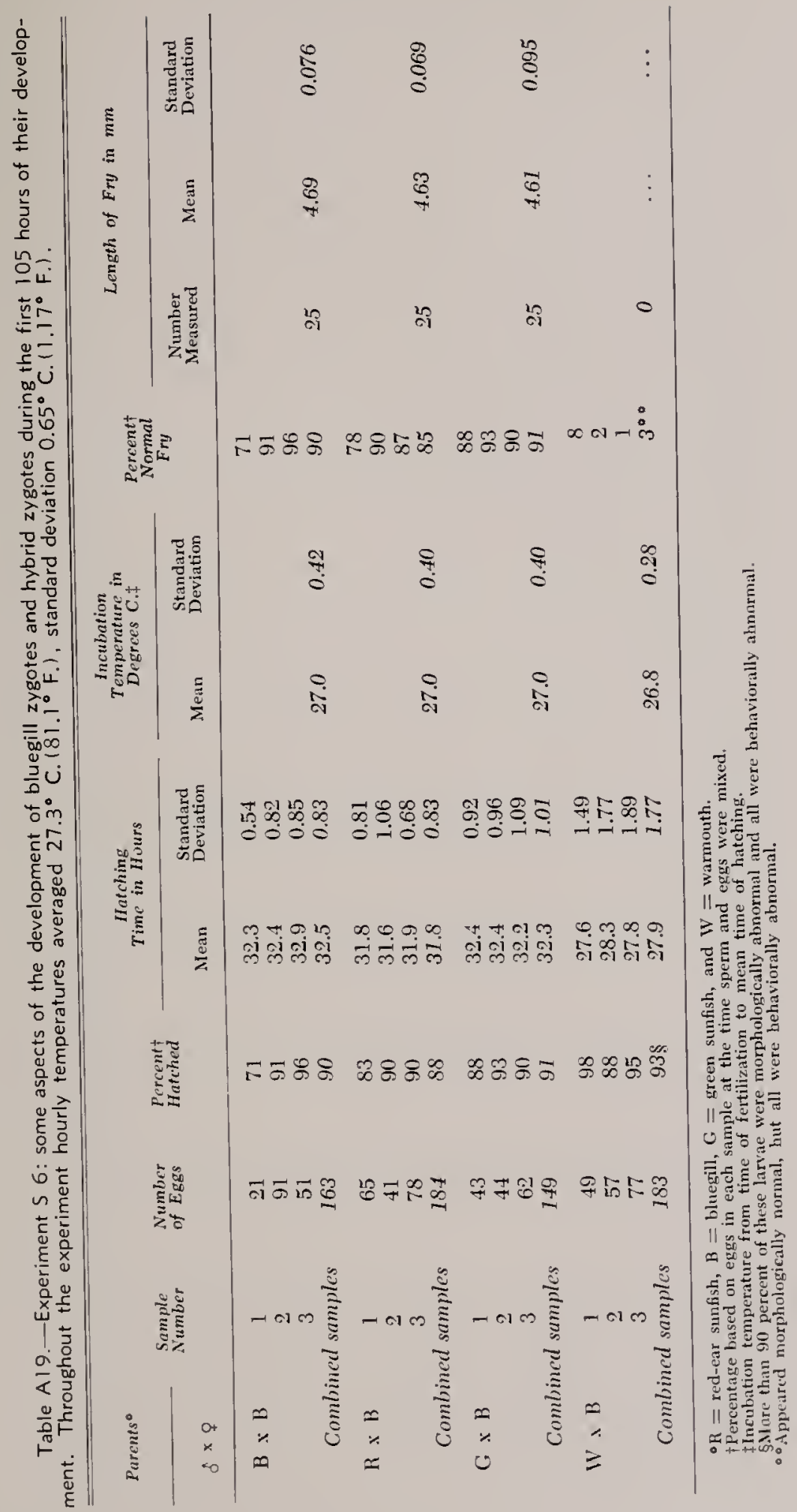




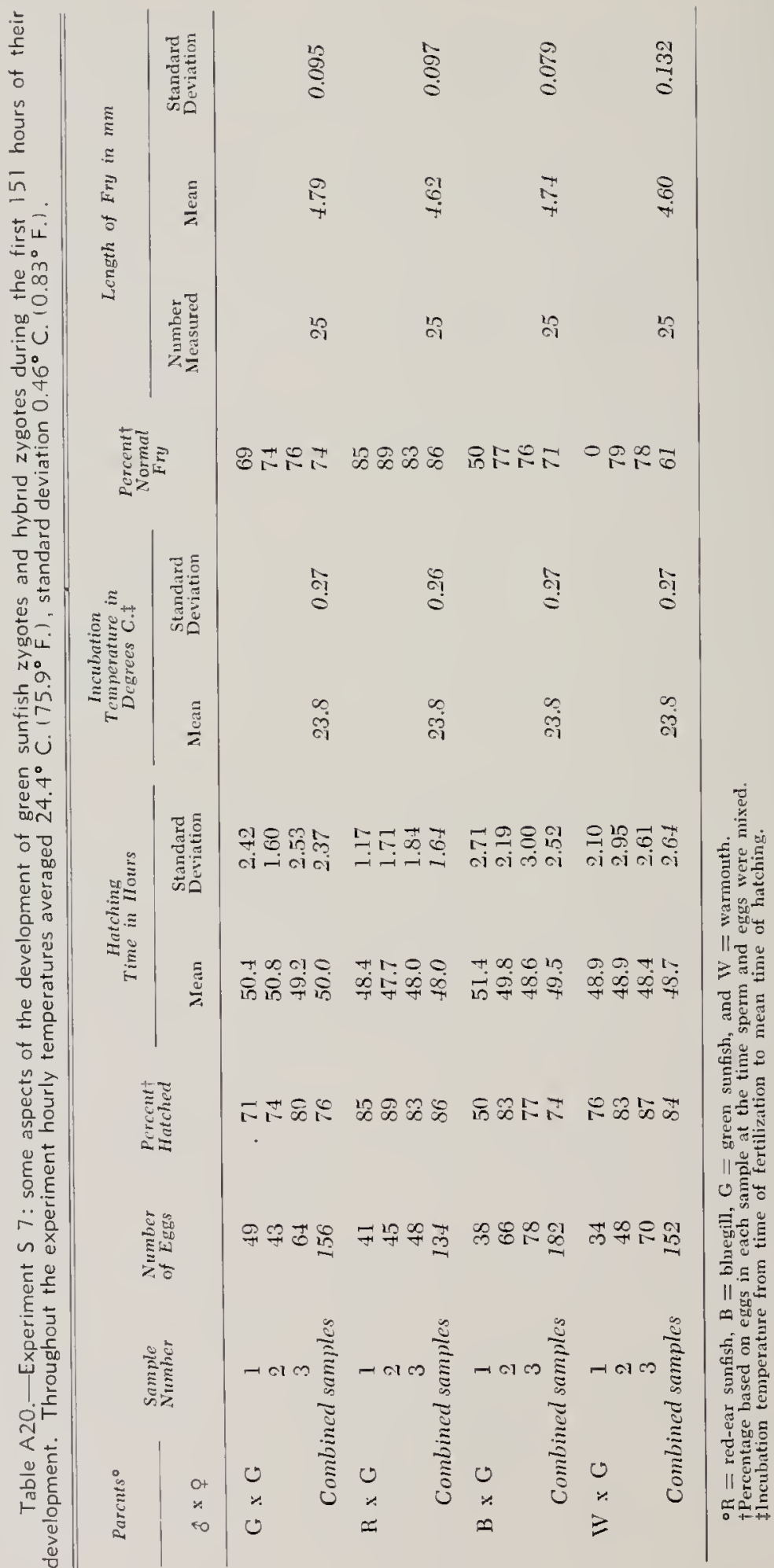




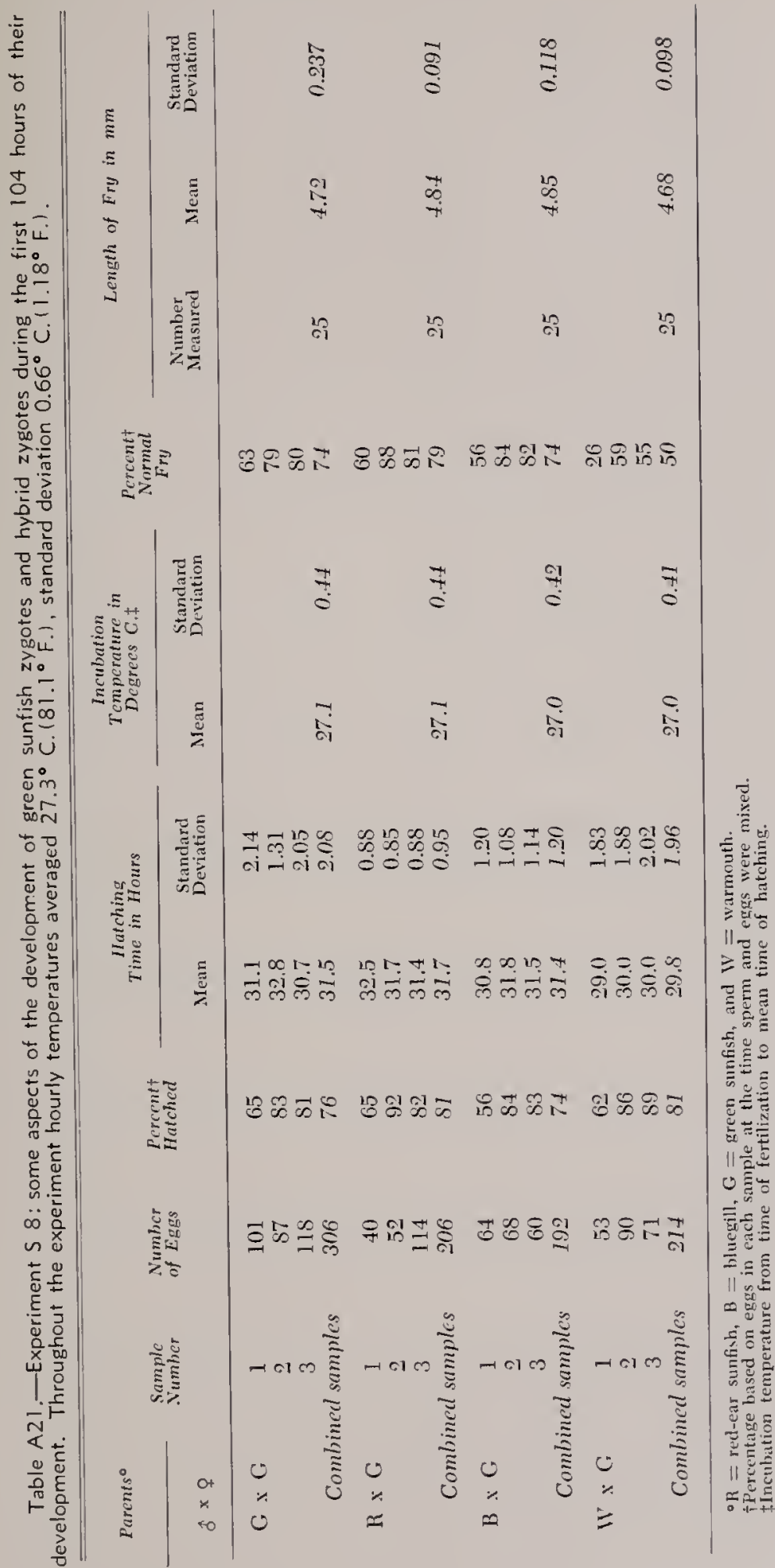




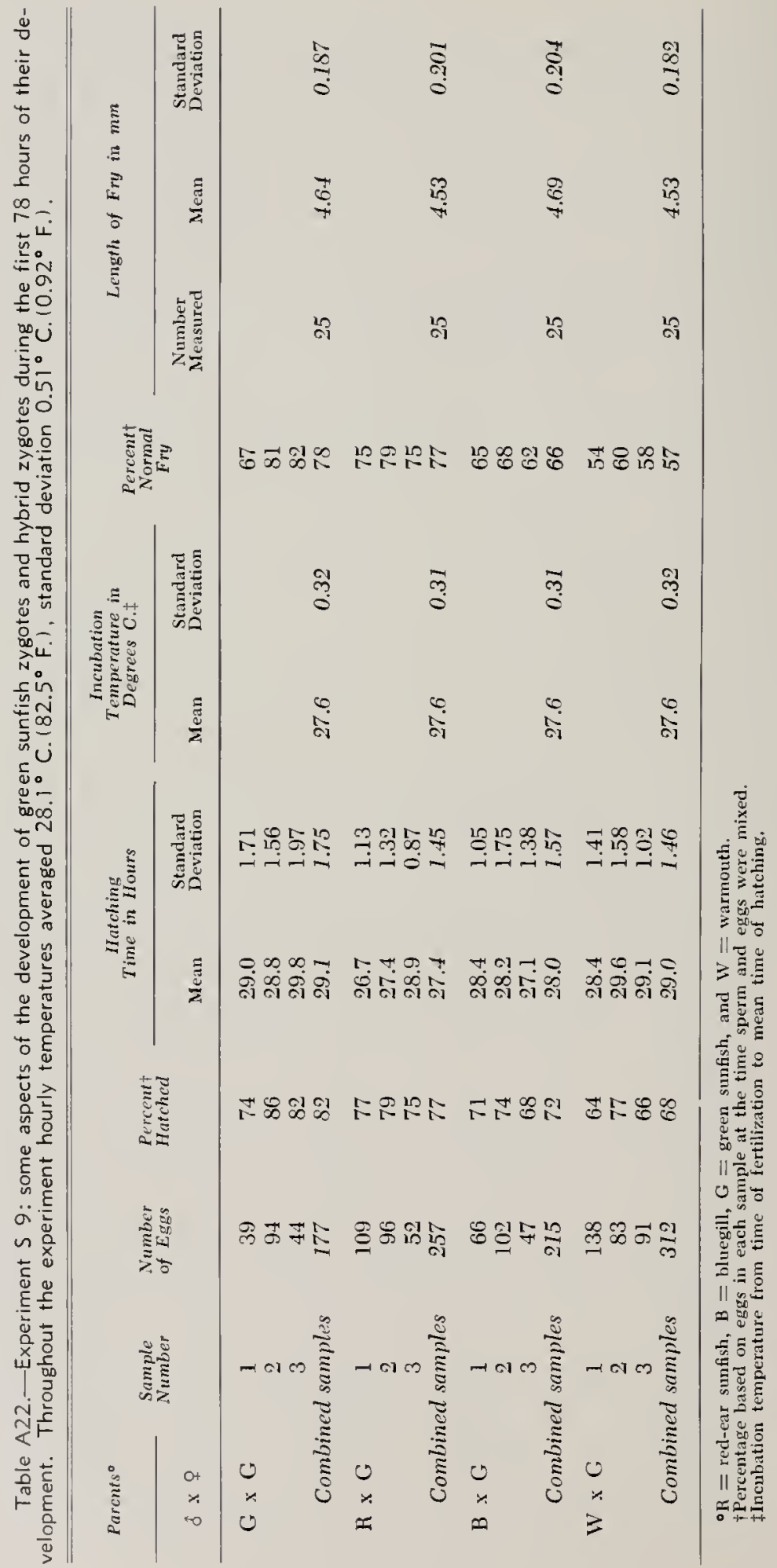




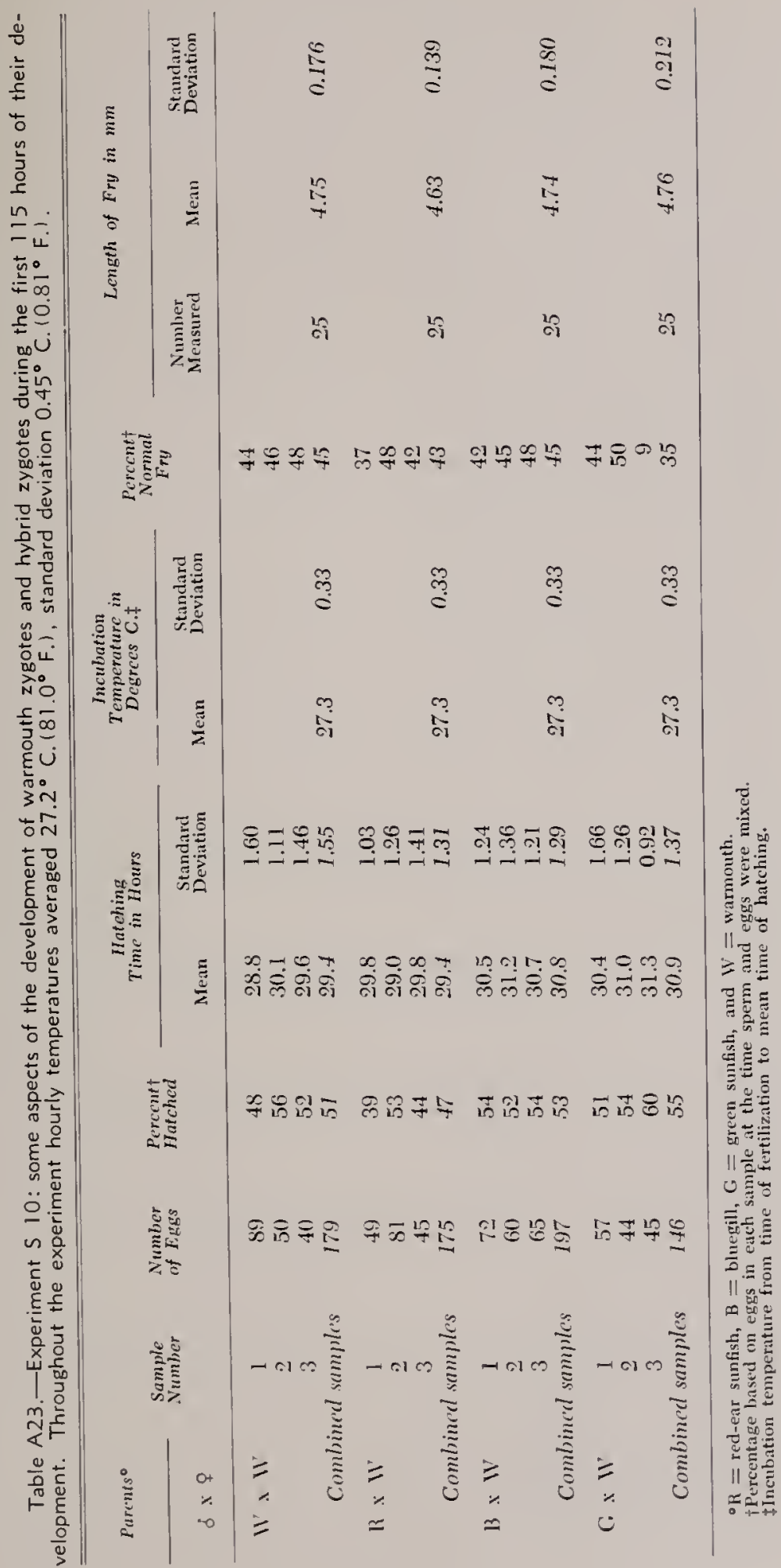




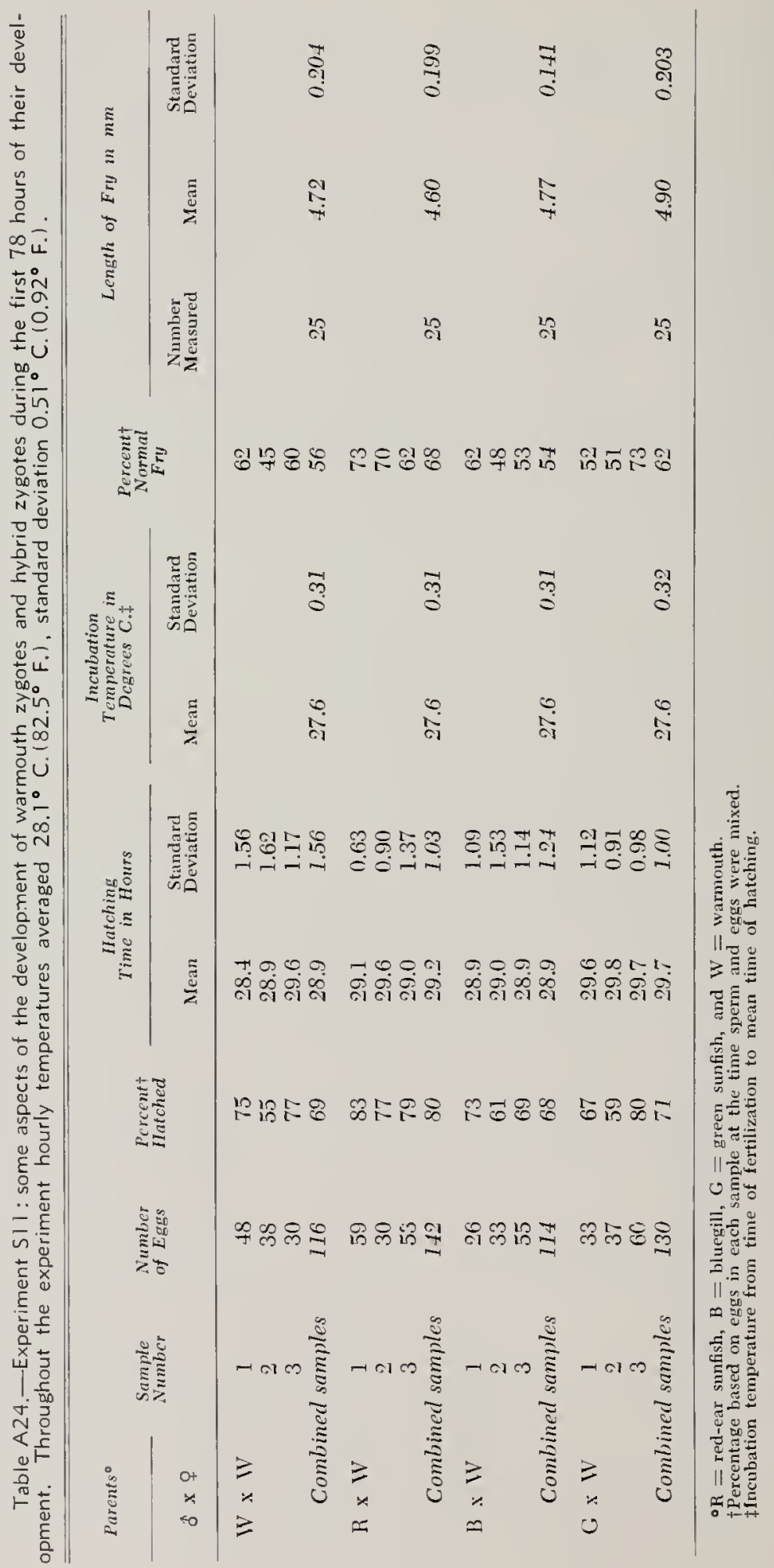




\section{INDEX}

\section{A}

Alpha temperature threshold of development, 179-181, 190

Archoplites interruptus, 160

\section{B}

Backcrossed hybrids, 186-187, 191

Bchavior of experimental species care of young, 167

haluitat selection, 162-163

nest location, 166-167

spawning behavior, 167, 183-184

spawning time, 163,166

Black crappie (fossils), 161

Bluegill

alpha temperature threshold of development, 179-181, 190

care of young, 167

chromosomes (number), 185

developmental units ( $\mathrm{U}$ values), 179-181, 190

eggs (see also Eggs), 167-171, 173, 176$178,180,196-197,203-205$

fry (body length), 171, 173, 179, 190, 203205

fry (free-swimming stage), 167

fry (swim-up stage), $171,173,176,178$ $179,203-205$

genetic sex, 185

geographic range, 162

growtl rate, $173,179,203-205$

habitat selection, 163

hatching time, 173, 177-179, 190, 203-205

hemoglobin, 189, 191

hybrids (natural), 161

incubation temperature, $168,171,173,178$ 179, 196-197, 203-205

morphological characteristics, 162, 164-165, 183

mortality (sec also viability), 170, 171, 181, 185

nest location, 166-167

reprochuctive isolating factors, $170,183-184$

spawning behavior, $167,183-184$

spawning time, 163,166

sperm (average functional life), 167-170, 190

viability (see also mortality), 170-171, 173 , $176-178,196-197,203-205$

Bluegill of Green of hybrids (see under Hybrids, $F_{1}, F_{2}$ generations)

Bluegill ô Red-ear o hybrids (see under $\mathrm{Hy}$ brids, $\mathrm{F}_{1}$ gencrations )

Bluegill of Warmouth o lyylurids (see under Hybrids, $F_{1}, F_{2}$ generations)

Care of young, 167

Catchability, 189, 191

Centrarchidie classification, 160

evolution, 159

geographic range, $160-161$

introgressive lybridization, 159

Chacnolurytius gulosus (sce Warmouth)

Chromosomes (number), 185

\section{D}

Deformities, 172-173, 176-178, 200-205

Developmental units (U values), 179-181, 190

\section{E}

$\operatorname{Egg}(s)$

average functional life, 167-170, 190

development into normal-appearing fry', $168-169,171-179,190,194-210$

mean number per sample, 171

ovulation, 183

physiological state, 168-169

size, 180

Evolution

Centrarchidae, 159

Lepomini, 159, 161-162

Experimental hyloridization

isolation experiments, 181-184

stripping experiments, $170-18 \mathrm{I}$

Experimental species (see also under individual species), 162,190

\section{$\mathbf{F}$}

$\mathrm{F}_{1}$ hybrids (see under Hybrids, $\mathrm{F}_{1}$ generations)

$\mathrm{F}_{2}$ hybrids (see under Hybrids, $\mathrm{F}_{2}$ generations)

$\mathrm{F}_{8}$ hybrids (see under Hybrids, $\mathrm{F}_{\mathrm{z}}$ generations)

Fecundity, 185-187, 190-191

Fossils

black crappie, 161

warmouth, 161

Four-species cross, 187

Fry (body length), 171-175, 179, 190, 200210

Fry (free-swimming stage), 167, 171, 184, 201-202

Fry (swim-up stage) , 171-176, 178-179, 200, 203-210

\section{G}

Gametrs (see also eggs and sperm under individual species)

average functional life, 167-170, 190

physiological stite, 168-169

stripping, 167,170

Gronctic sex, 185

Geograpluic range

Contrarchidie, 160-161

experimentil species, 162

Crecen of Bluegill of hylorids (see under $\mathrm{H}_{y}$ brids, $F_{1}, F_{2}$ generations ) 
Green of Red-ear o hyhrids (see under Hybrids, $F_{1}, F_{2}$ generations)

Green \& Warmouth $q$ hybrids (see under Hybrids, $F_{1}, F_{2}, F_{3}$ generations)

Creen sunfish

alpha temperature thresholk of development, 179-181, 190

care of young, 167

chromosomes (number), 185

developmental units ( $\mathrm{U}$ values), 179-181, 190)

eggs (see also Eggs), 167-171, 174, 176177, I80, 190, 198-199, 206-208

fry (body length), I71, 174, 179, 190, 206208

fry (free-swimming stage), 167

fry (swim-up) stage), I7 I, I74, 176, 179, 206-208

genetic sex, 185

geographic range, 162

growth rate, $174,179,188,191,206-208$

habitat selection, 162-163

hatching time, 174, 177-179, 190, 206-208

liemoglobin, 189, 191

hybrids (natural), 161

incubation temperature, $168,171,174,179$, 198-199, 206-208

morphological characteristics, 162, 164-165, 183

mortality (see also viability), 170-I71, 181, 185

nest location, 166-167

reproductive isolating factors, $170,183-184$

spawning behavior, 167, 183-184

spawning time, 163,166

sperm (average functional life), 167-170, 190

viability ( see also mortality), 170-171, 174, $176-177,198-199,206-208$

Crowth rate, $172-175,179,187-191,200-210$

\section{$\mathrm{H}$}

Habitat selection, 162-163

Hatching time，17I-175，177-179，190, 200210

Hemoglobin, 189, 191

Heterosis (hybrid vigor), 187-189, 19 I

Hybridization

experimental, 170-184

introgressive, 159

natural, 159, 161-162, 182, 190

reproductive isolating factors, $170,183-184$

Hyl)ricl ( $s$ )

backcrossed generations, 186-187

definition, 159

fonr-species crosses, 187

natural, 159, 161-162, 182, 190

outerossed generations, 187

three-species crosses, 187

Hybrid(s), $F_{1}$ generations

alpha temperature threshold of development, $179-181,190$
Bluegill of Green o $F_{1}$ hylurids, 161, 174, $176-177,179-181,184-186,188-191,206-$ 208

Bluegill \& Red-ear o $\mathrm{F}_{1}$ hybrids, I6I, 172, $176-177,179-182,184-186$, 189-191, 200202

Bluegill of Warmonth $q \mathrm{~F}_{1}$ hybrids, 161, $175-177,179,181-182,184-186,189-191$, 209-210

catchability, 189, 19 I

chromosomes (number), 185

definition, 170

deformities, 172-173, 176-178, 200-205

developmental mits ( $U$ values), 179-181, 190

fecundity, 185-187, 190-191

fry (body length), 171-175, 179, 190, 200210

fry (free-swimming stage), 177, 179, 184

fry (swim-up stage), 171-176, 178-179, 200, 203-210

Green of Bluegill of $\mathrm{F}_{1}$ hybrids, frontisviece, 161, 173, 176-177, 179-182, 184186, 188-191, 203-205

Green of Red-ear o $\mathrm{F}_{1}$ hybrids, 161, 172, $176-177,179-182,184-186,188-191,200-$ 202

Creen of Warmouth $\& \mathrm{~F}_{1}$ hybrids, 161, $175-177,179,181-182,184-186,189-191$, 209-210

growth rate, 172-175, 179, 187-189, 191, 200-210

hatching time, 172-175, 177-179, 190, 200210

hemoglobin, 189, $19 \mathrm{I}$

heterosis (hybrid vigor), 187-189, 191

incubation temperature, 171-175, 177-179, $200-210$

isolation experiments, 181-184

mortality (see also viability), 171, 176, 181, 190

Red-ear \& Blnegill o $\mathrm{F}_{1}$ hybrids, 161, 173, 176-177, 179-186, 189-191, 203-205

Red-ear of Green $\$ F_{1}$ hyhrids, 161, 174, $176-177,179-182,184-186,189-191,206-$ 208

Red-ear of Warmouth o $F_{1}$ hybrids, 161, 175-179, 181-182, 184-186, 188-191, 209210

sex ratio, 184-185, 190-191

sport fishing, 189-191

stripping experiments, 170-181, 200-210

temperature (incubation), 171-175, 177 180, 200-210

viability (see also mortality), 170-178, 190, 200-2I0

Warmouth o Blnegill of $F_{1}$ hybrids, 16I, $173,176-182,190,203-205$

Warmonth of Green $\$ F_{1}$ hybrids, 161, 174 , $176-177,179-182,184-186,189-191,206-$ 208 
Warmouth o Red-ear \& F, lybrids, 161, 172, 176-182, 190, 200-202

Hybrid (s), F, generations, 170, 185-187, 190 191

Bluegill \& Green $q F_{2}$ hybrids, 186

Bluegill of Red-ear of $\mathrm{F}_{2}$ hybrids, 186

Bluegill o Warmouth $q \mathrm{~F}_{2}$ hybrids, 186, 191

Green $\delta$ Bluegill $\circ \mathrm{F}_{2}$ hybrids, 186, 191

Green of Red-ear $\& \mathrm{~F}_{2}$ hybrids, 186, 191

Green of Warmouth of $\mathrm{F}_{\mathrm{n}}$ hybrids, 186-187, 191

Red-ear \& Bluegill \& $\mathbf{F}_{2}$ hybrids, 186

Red-ear of Green $q \mathrm{~F}_{2}$ hybrids, 186, 191

Red-ear \& Warmoutl o $\mathbf{F}_{2}$ hybrids, 186, 191

Warmouth of Green of $\mathrm{F}_{2}$ hybrids, 186-187, 191

Hybrid(s), $\mathrm{F}_{3}$ generations, 187

Green \& Warmouth $q \mathbf{F}_{3}$ hybrids, 187, 191

Warmouth of Green o $\mathrm{F}_{3}$ hybrids, 187, 191

Incubation temperature, 168, 171-175, 177 I80, 194-210

Introgressive hybridization, 159

Isolation experiments, 181-184

Lepomini (tribe)

elassification, 160

evolution, 159, 161-162

hybridization (experimental), 170-184

hybridization (natural), 159, 161-162, 182

Lepomis cyanellus (see Green sunfish)

Lepomis macrochirus (see Bluegill)

Lepomis microloplus (see Red-ear sunfish)

\section{$M$}

Morphological characteristies, 162, 164-165, 183

Mortality (see also Viability), 170-171, 176 , $181,185,190-191$

\section{$\mathrm{N}$}

Natural hybrids, 159, 161-162, 182, 190

Natural hybridization, $159,161-162,182,190$

Nest location(s), 166-167

\section{0}

Outcrossed gencrations, 187

\section{$\mathbf{P}$}

Parental species (see also under individual species), 162, 190

\section{$R$}

Rocd-ear \& Bluegill of hylurids (see under Hybrids, $F_{1}, F_{2}$ generations)

Red-ear of Geen of liybrids (see under $1 \mathrm{Iy}$ brids, $F_{1}, F_{2}$ generations)
Red-ear of Warmouth of hybrids (see muler Hybrids, $F_{1}, F_{2}$ generations)

Red-ear simfish

alpha temperature threshold of development, 179-181, 190

care of young, 167

chromosomes (number), 185

developmental units (U values), 179-181, 190

eggs (sec also Eggs), 167, 170-172, $176-$ $177,180,190,200-202$

fry (body length), 171-172, 179, 190, 200. 202

fry (free-swimming stage), 167, 171-172, $177,179,201-202$

fry (swim-up stage), 171-172, 176, 179, 200

genetic sex, 185

geographic range, 162

growth rate, 172, 179, 188, 190-191, 200. 202

habitat selection, 163

hatching time, 172, 177-179, 190, 200-202

hemoglobin, 189,191

hybrids (natural), 161

incubation temperature, 171-172, 177, 179, 200-202

morphological characteristies, 162, 164-165, 183

mortality (see also viability), 171, 181, 185 nest location, 166-167

reproductive isolating factors, $170,183-184$

spawning behavior, $167,183-184$

spawning time, 163, 166

sperm (average functional life), 170

viability (sce also mortality), 170-172, 176 $177,190,200-202$

Reproductive isolating factors, 170, 183-184

\section{$S$}

Sacramento perch, 160

Sex ratio, 184-185, 190-191

Spawning behavior, 167, 183-184

Spawning time, 163, 166

Sperm (average funetional life), 167-170, 190

Sperm driftage, 167, 170, 190

Sport fishing (hybrids), 189-191

Stripping experiments, 170-181

\section{T}

Temperature (incubation), 168, 171-175, 177$180,194-210$

Three-species crosses, 187

U

U values (developmental units), 179-181, 190)

\section{V}

Vialbility (see also Mortality), 170-178, 190, 194-2I0 


\section{W}

Warmouth

alpha temperature threshold of development, 179-181

care of young, 167

chromosomes (number), 185

developmental units ( $U$ values), 179-181, 190

eggs (see also Eggs), 167-171, 175-177, 179-180, 194-195, 209-210

fossils, 161

fry (body length), 171, 175, 179, 190, 209210

fry (free-swimming stage), 167

fry (swim-up stage), 171, 175-176, 179, 209-210

genetic sex, 185

geographic range, 162

growth rate, $175,179,190,209-210$

habitat selection, 162

hatching time, $175,177-179,190,209-210$

hemoglobin, 189, 191 hybrids (natural), 161, 190

incubation temperature, 168, 171, 175, 179, 194-195, 209-210

morphological characteristics, 162, 164-165, 183

mortality (see also viability), 170-171, 181, 185,190

nest location, 166-167

reproductive isolating factors, $170,183-184$ spawning behavior, 167, 183-184

spawning time, 163,166

sperm (average functional life), 167-168, 170,190

viability (see also mortality), 170-171, 175$177,190,194-195,209-210$

Warmouth of Bluegill $q$ hybrids (see under Hybrids, $F_{1}$ generations)

Warmouth of Green $\&$ hybrids (see under Hybrids, $F_{1}, F_{2}, F_{3}$ generations )

Warmouth of Red-ear $q$ hybrids (see under Hybrids, $F_{1}$ generations ) 


\title{
Some Publications of the ILLINOIS NATURAL HISTORY SURVEY
}

\section{BULLETIN}

Volume 27, Article 5.-Hook-and-Line Catch in Fertilized and Unfertilized Ponds. By Donald F. Hansen, George W. Bennett, Robert J. Webb, and John M. Lewis. August, 1960. 46 p., frontis., 11 fig., bibliogr.

Volume 27, Article 6.-Sex Ratios and Age Ratios in North American Ducks. By Frank C. Bellrose, Thomas G. Scott, Arthur S. Hawkins, and Jessop B. Low. August, 1961. 84 p., 2 frontis., 23 fig., bibliogr.

Volume 28, Article 2.-The Fishes of Champaign County, Illinois, as Affccted by 60 Years of Stream Changes. By R. Weldon Larimore and Philip W. Smith. March, 1963. 84 p., frontis., 70 fig., bibliogr., index.

Volume 28, Article 3.-A Comparative Study of Bird Populations in lllinois, 1906-1909 and 1956-1958. By Richard R. Graber and Jean W. Graber. Octobcr, 1963. 146 p., 4 frontis., 32 fig., bibliogr., index.

Volume 29 , Article 1.-A Biological Investigation of the Fishes of Lake Chautauqua, Illinois. By William C. Starrett and Arnold W. Fritz. March, 1965. 104 p., frontis., 40 fig., bibliogr., index.

Volume 29, Article 2.-Stocking and Sport Fishing at Lake Glendale (Illinois). By Donald F. Hansen. July, 1966. 54 p., frontis., 9 fig., bibliogr., index.

\section{CIRCULAR}

39. - How to Collect and Preserve Insects. By H. H. Ross. November, 1966. (Eighth printing.) $7 \mathrm{i}$ p., frontis., 79 fig.

46.-Illinois Trees: Their Diseases. By J. Cedric Carter. June, 1964. (Third printing, with alterations.) 96 p., frontis., 89 fig.

47.-Illinois Trees and Shrubs: Their Insect Enemies. By L. L. English. October, 1965. (Third printing, with revisions.) 92 p., frontis., 59 fig., index.

48.-Diseases of Wheat, Oats, Barley, and Rye. By G. H. Boewe. June, 1960. 159 p., frontis., 56 fig.

49. - The Dunesland Heritage of Illinois. By Herbert H. Ross. (In cooperation with Illinois Department of Conservation.) August, 1963. 28 p., frontis., 16 fig., bibliogr.

50.-The Wetwood Disease of Elm. By J. Cedric Carter. May, 1964. 20 p., 19 fig.
51.-Illinois Trees: Selection, Planting, and Care. By J. Cedric Carter. August, 1986. 123 p., frontis., 108 fig.

52.-Fertilizing and Watering Trees. By Dan Neely and E. B. Himelick. September, 1966. 20 p., 9 fig., bibliogr.

\section{BIOLOGICAL NOTES}

43.-Hot-Water and Chemical Treatment of Illinois-Grown Gladiolus Cormels. By J. L. Forsberg. March, 1961. 12 p., 8 fig., bibliogr.

44.-The Filmy Fern in Illinois. By Robert A. Evers. April, 1961. 15 p., 13 fig., bibliogr. 48. - Systemic Insecticide Control of Some Pests of Trees and Shrubs-A Preliminary Report. By L. L. English and Walter Hartstim. August, 1962. 12 p., 9 fig., bibliogr. 50.- Some Unusual Natural Areas in Illinois and a Few of Their Plants. By Robert A. Evers. July, 1963. 32 p., 43 fig., bibliogt. 52.-A Synopsis of the Mosquitoes of Mlinois (Diptera, Culicidae). By Herbert H. Ross and William R. Horsfall. March, 1965. 50 p., 231 fig., bibliogr., index.

53.- Experimental Field Studies on Shade Tree Fertilization. By E. B. Himelick, Dan Neely, and Webster R. Crowley, Jr. June, 1965. 12 p., 8 fig., bibliogr.

54.-A Preliminary Annotated List of the Lampreys and Fishes of Illinois. By Philip W. Smith. June, 1965. 12 p., 3 fig., bibliogr.

55.-A Guide to Age Determination of Bobwhite Quail Embryos. By John Roseberry and Willard D. Klimstra. July, 1965. 4 p., 2 fig., bibliogr.

57.-Man's Effect on the Fish and Wildlife of the Illinois River. By Harlow B. Mills, William C. Starrett, and Frank C. Bellrose. June, 1966. 24 p., 16 fig., bibliogr.

58.- The Life History of the Slough Darter, Etheostoma gracile (Pisces, Percidae). By Marvin E. Braasch and Philip W. Smith. June, 1967. 12 p., 8 fig., bibliogr.

\section{MANUAL}

4.-Fieldbook of Illinois Mammals. By Donald $F$. Hoffmeister and Carl $O$. Mohr. June, 1957. 233 p., color frontis., 119 fig., glossary, bibliogr., index.

\section{List of available publications mailed on request}

No charge is made for publications of the Illinors Natural Hrstory Survex. A single copy of most publications will be sent free to anyone requesting it until the supply becomes low. Costly publications, more than one copy of a publication, and publications in short supply are subjects for special correspondence. Such correspondence should identify the writer and explain the use to be made of the publication or publications.

\author{
Address orders and correspondence to the Chief, \\ Illinois Notural History Survey, \\ Natural Resources Building, Urbana, Illinois 61801
}

